\title{
Joaquín Costa
}

DISCURSOS LIBRECAMBISTAS

Edición de José María Serrano Sanz

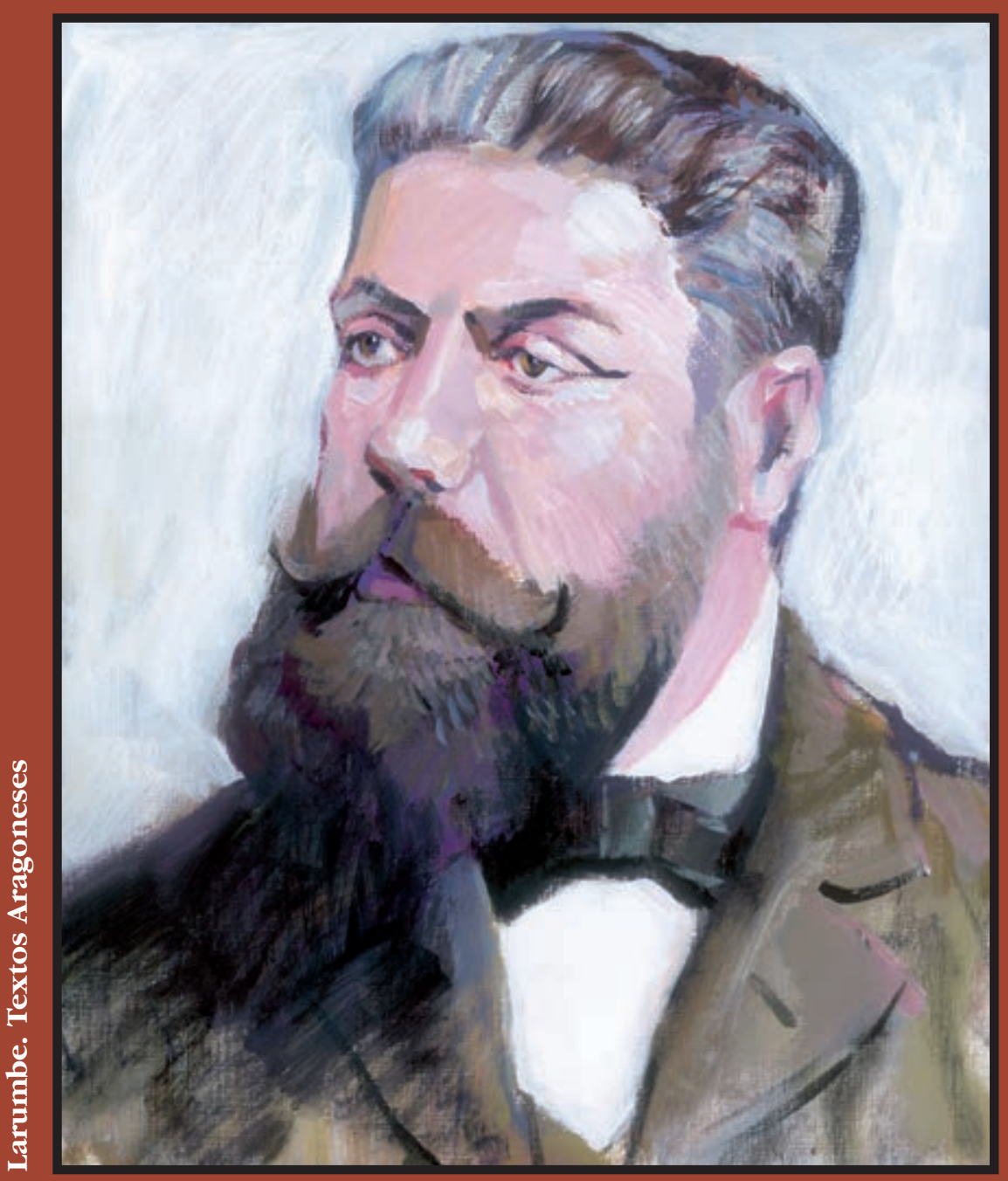


Larumbe. Textos Aragoneses, 70

Historia y Pensamiento

\section{0}

Directores de la colección:

Fermín Gil Encabo, Antonio Pérez Lasheras

y Ángel San Vicente Pino

Comité editorial: José Domingo Dueñas Lorente, Ángel Gari Lacruz,

José Enrique Laplana Gil, Alberto Montaner Frutos,

Eliseo Serrano Martín, José Manuel Latorre Ciria,

Ángel Garcés Sanagustín, Francho Nagore Laín,

Guillermo Pérez Sarrión y Alberto del Río Nogueras

Corrección: Teresa Sas Bernad y Ana Bescós García

Secretaría: Servicio de Publicaciones de la Universidad

de Zaragoza 
JOAQUÍN COSTA

DISCURSOS LIBRECAMBISTAS 

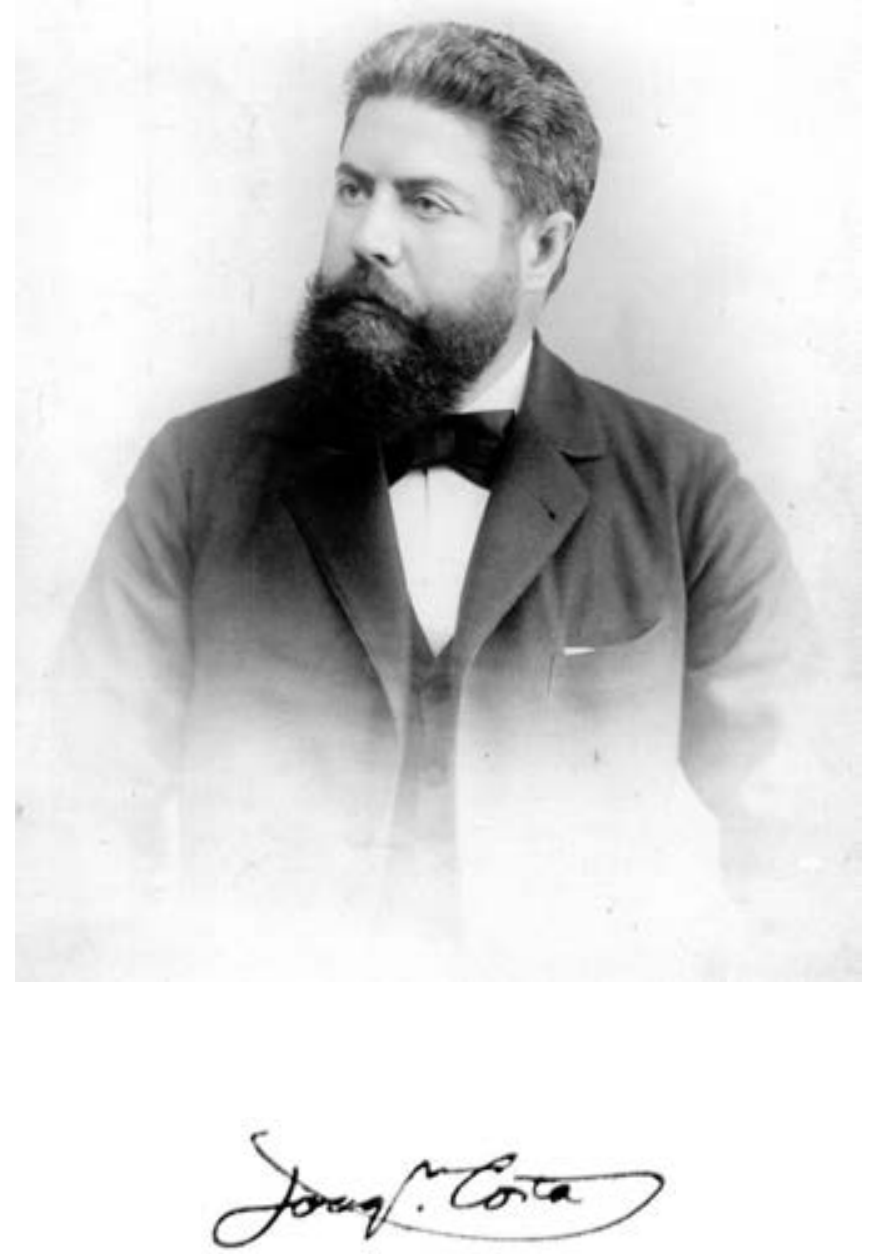

Retrato y firma de Joaquín Costa 


\title{
JOAQUÍN COSTA \\ DISCURSOS LIBRECAMBISTAS
}

\author{
Edición, introducción y notas de \\ JOSÉ MARÍA SERRANO SANZ
}

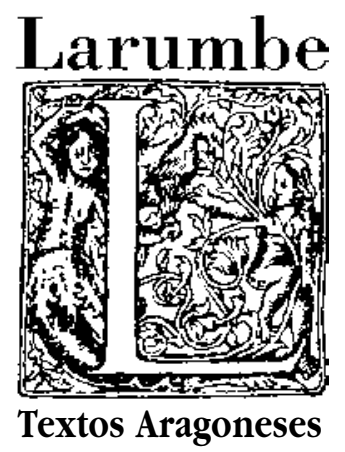

Prensas Universitarias de Zaragoza Instituto de Estudios Altoaragoneses Instituto de Estudios Turolenses

Depto. de Educación, Cultura y Deporte del Gobierno de Aragón 
COSTA, Joaquín

Discursos librecambistas / Joaquín Costa ; edición, introducción y notas de José María Serrano Sanz. - Zaragoza : Prensas Universitarias de Zaragoza : Departamento de Educación, Cultura y Deporte del Gobierno de Aragón ; Huesca : Instituto de Estudios Altoaragoneses ; Teruel : Instituto de Estudios Turolenses, 2011

LXX, 138 p. ; 21 cm. — (Larumbe : Textos Aragoneses ; 70. Historia y Pensamiento)

Bibliografía: p. 129-134. — ISBN 978-84-15274-14-8

SERRANO SANZ, José María

33(081)Costa, Joaquín

(C) José María Serrano Sanz

(C) De la presente edición, Prensas Universitarias de Zaragoza, Instituto de Estudios Altoaragoneses, Instituto de Estudios Turolenses y Departamento de Educación, Cultura y Deporte del Gobierno de Aragón

1. ${ }^{\mathrm{a}}$ edición, 2011

Prensas Universitarias de Zaragoza. Edificio de Ciencias Geológicas, c/ Pedro Cerbuna, 12. 50009 Zaragoza, España. Tel.: 976761 330. Fax: 976761063 puz@posta.unizar.es http://puz.unizar.es

Instituto de Estudios Altoaragoneses (Diputación de Huesca), c/ Parque, 10. 22002 Huesca, España. Apartado postal 53. Tel.: 974294 120. Fax: 974294122 iea@iea.es http://www.iea.es

Instituto de Estudios Turolenses (Diputación de Teruel), c/ Amantes, 15, 2. ${ }^{a}$ planta. 44001 Teruel, España. Tel.: 978617 860. Fax: 978617861 ieturolenses@dpteruel.es http://www.ieturolenses.org

Departamento de Educación, Cultura y Deporte del Gobierno de Aragón. Edificio Pignatelli, paseo María Agustín, 36. 50004 Zaragoza, España

Diseño de cubierta: José Luis Cano

Impreso en España

Imprime: INO Reproducciones, S.A.

D.L.: Z-1912-2011 
JOAQUÍN COSTA, LIBRECAMBISTA* 



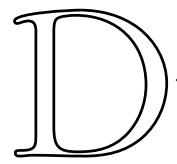

URANTE LOS AÑOS OCHENTA del siglo XIX, Joaquín Costa fue un destacado activista en favor del librecambio. Fue vocal en la Junta directiva de la organización librecambista Asociación para la Reforma de los Aranceles de Aduanas, donde pronunció cuatro resonantes discursos que, con un quinto del mismo tenor en un Congreso de Agricultores, son piezas básicas para conocer su pensamiento sobre economía y sus tempranas inquietudes reformistas. Los discursos son incluso claves para conocer a la persona, porque en la imagen más popularizada de Costa pesa demasiado la figura del retirado de Graus y, por ese conducto, el personaje un poco atrabiliario, que vive en soledad desencantado de todo. El Costa de los ochenta, tan real como el otro, es un hombre que se multiplica en actividades y organizaciones diversas, que no rehúye la comparecencia pública en mítines o congresos y aparece con frecuencia en la prensa. Comparte con numerosos amigos proyectos, banquetes y hasta excursiones dominicales y está bien integrado en la vida intelectual y social del momento. Por supuesto, es una personalidad fuerte y singular, como siempre lo fue, pero en modo alguno un solitario.

En nuestra opinión, su faceta librecambista ilustra bien estas otras dimensiones de Joaquín Costa. Y considerando la importancia que las controversias sobre política arance-

* Agradezco a Marcela Sabaté Sort sus comentarios y sugerencias. 
laria tuvieron en aquel tiempo sorprende que su activismo apenas haya sido mencionado en los múltiples trabajos que versan sobre él. Este vacío puede deberse a que el Costa economista siempre ha estado en un segundo plano frente al político, el jurisconsulto o el erudito. O tal vez la razón sea, simplemente, que de los cinco textos mencionados, Costa solo recogió uno en Estudios jurídicos y políticos y su hermano Tomás otro en Agricultura armónica, quedando los demás en la penumbra de los escasamente conocidos folletos originales de la Asociación para la Reforma de los Aranceles de Aduanas. Esta falta de conocimiento es lo que trata de remediarse con nuestra edición, también conmemorativa de su centenario.

El presente estudio preliminar se organiza en cinco apartados. En el primero se rastrean los orígenes del interés de Costa por la economía y por el librecambio en particular. En el segundo apartado se presta atención a los ambientes librecambistas en aquellos años, al papel desempeñado por Costa y al reflejo de sus discursos en la prensa y la opinión. En el tercero se habla del contexto, es decir, de la política arancelaria española y las controversias contemporáneas, a fin de hacer comprensibles las posiciones costianas por contraste con su entorno. En el cuarto apartado se analiza la argumentación de Costa, para extraer sus ideas sobre política comercial. Finalmente, en el quinto, se comenta la procedencia de los textos.

\section{LOS ORÍGENES DEL LIBRECAMBISMO COSTIANO}

¿Cómo llegó Joaquín Costa a ser partidario de la libertad comercial, a convertirse incluso en propagandista del librecambio? En nuestra opinión, son dos las raíces de su actitud ante la cuestión arancelaria. Por una parte, el tema no podía serle ajeno, dado su interés temprano por la economía, el protagonismo que en la época tuvieron las con- 
troversias arancelarias y la orientación liberal predominante en la enseñanza universitaria de la economía. Por otra, hay que considerar el papel que los institucionistas tuvieron en el activismo librecambista y la sistemática participación de Costa en sus iniciativas, en particular durante los años ochenta. Interés por la economía y afinidad con el institucionismo eran rasgos profundamente arraigados en el Costa joven, que ayudan a situarlo en términos generacionales en torno al 68 y de los cuales el librecambismo, más que una opción, era una manifestación. De modo que su posición librecambista no resultó una anécdota en su trayectoria, sino una consecuencia lógica de su formación y preferencias.

Pero vayamos por partes. Primero, en cuanto a la economía, debe decirse que sintió por ella un interés temprano que mantuvo a lo largo de toda su vida, como no podía ser menos en alguien comprometido con la reforma de la realidad material de los españoles. ${ }^{1}$ Su viaje a Francia en 1867 le fue decisivo para adquirir conciencia del atraso en que se encontraba España y comenzar una reflexión sobre los medios apropiados para remediarlo que acabó por ser de largo alcance. ${ }^{2}$

Esa preocupación inicial por el atraso debió de ser un poderoso estímulo para estudiar economía en sus tiempos universitarios e incluso para pensar en dedicarse profesionalmente a la misma. El 29 de junio de 1873 escribió en su Diario un párrafo que no puede ser más expresivo: «En esto [se refiere al futuro inmediato] ¿qué papel puede tocarme a mí? Si fuese catedrático en Madrid, ser uno de estos propagandistas racionales, con predominio de la cuestión económica, durante estos diez o doce años; fundar escuela,

1 Una visión general del Costa economista, en J. M. ${ }^{a}$ Serrano Sanz (2011a).

2 Así lo vio, entre otros, R. Pérez de la Dehesa (1966), pp. 16 y ss. También, E. Fernández Clemente (1989), p. 163. 
formar un núcleo de racionalistas armónicos en Economía, y a la caída de D. Alfonso, ser Gobierno. Esto puede ser si consigo ser profesor de Economía en Madrid; si no, nada" (la cursiva es nuestra). ${ }^{3}$ En el verano del mismo año 1873, pasó un tiempo "haciendo una Memoria sobre el Concepto y Plan de la Economía para las oposiciones de auxiliar de la Facultad de Filosofía que no se han verificado por haberse suspendido los decretos de Reforma en la Universidad", según escribió asimismo en su Diario. ${ }^{4}$ En 1874 dudaba entre el derecho político y la economía, aunque concluía: "las dos cosas debo hacer, como Stuart Mill y otros". 5 Después, sin embargo, abandonó su pretensión de convertirse en profesor universitario y el abanico de sus intereses se amplió, quizá en exceso, como señaló Cheyne.

En cualquier caso, el aprendizaje de la disciplina económica se hizo en el marco de sus estudios universitarios, cuando en la España de finales de los sesenta y comienzos de los setenta las ideas dominantes en el profesorado y los libros de texto eran las liberales. ${ }^{6}$ En docencia dominaba abrumadoramente la llamada escuela economista, defensora de un liberalismo radical de tipo manchesteriano, que llegó a España a través de la interpretación de la escuela optimista francesa. ${ }^{7}$ La confianza en que la libertad

3 Debo los textos del Diario a la amabilidad de Juan Carlos Ara, quien prepara una edición completa del mismo, que aparecerá en breve en esta misma colección Larumbe. A. del Olmet (s. f.), p. 83, lo citaba, aunque con un error de transcripción, pues hablaba de "nacionalistas" en lugar de "racionalistas".

4 Anotación del 24 de noviembre de 1873 en el Diario. Véase también G. J. G. Cheyne (1972), p. 82.

5 Anotación del 10 de septiembre de 1874.

6 Sobre los primeros pasos de Costa en la economía, véase J. M. Serrano Sanz (2011b).

7 Sobre los liberales españoles y la escuela economista, véase el volumen 4 de E. Fuentes Quintana (dir.) (2000); en especial, S. Almenar (2000), E. Lluch y S. Almenar (2000) y C. Lebón Fernández y R. Sánchez Lissen (2000). Consúltese también R. Román (2003). 
completa de la iniciativa individual y el mínimo de intervención pública eran las garantías del progreso estaba profundamente arraigada. Por supuesto, el librecambio era un principio básico para la escuela economista.

Durante el Sexenio, la escuela economista no solo dominaba las cátedras, sino que alcanzó el poder político y pudo llevar a la práctica muchas de sus ideas, promoviendo una liberalización general de la economía española, que incluyó la reforma arancelaria de 1869. Será entonces precisamente cuando se produzcan las primeras críticas al liberalismo extremo que la escuela economista patrocinaba, críticas centradas no tanto en el ámbito de las políticas y las realizaciones cuanto en el de los principios y las teorías. El movimiento crítico, sin embargo, no fue exclusivo de España, pues al comenzar el último tercio del XIX se produjo en toda Europa un cambio significativo en el mundo de las ideas económicas, que Schumpeter resumió diciendo que entonces "se rompió la alianza de la economía y el liberalismo". ${ }^{8}$ Gradualmente muchos estudiosos de la economía fueron perdiendo la confianza en que el libre mercado y la completa libertad de iniciativa individual fueran capaces de garantizar el progreso permanente y se abrió paso la idea de que ciertas intervenciones gubernamentales tenían sentido. La conciencia de que la cuestión social no se arreglaba de forma espontánea y las crisis económicas podían derivar en trastornos políticos obligaron a ensanchar el catálogo de las medidas aceptables en política económica. Los liberales extremos fueron pareciendo cada vez más cosa del pasado y una amplia gama de posiciones revisionistas e intervencionistas se abrió paso.

En dicho contexto internacional y por la misma época aparecieron las disidencias españolas con la escuela eco- 
nomista iniciadas en el seno del krausismo, como señalara Gabriel Franco. ${ }^{9}$ Hasta entonces los krausistas habían pertenecido enteramente al grupo de la escuela economista, pero a comienzos de los setenta, nada menos que Francisco Giner de los Rios y Gumersindo de Azcárate tomaron distancia con el liberalismo económico radical de sus antiguos correligionarios. El primer hito lo constituyeron las Lecciones sobre filosofía del derecho dictadas por Giner en la Universidad de Madrid durante el curso 187374 , en las que consideró necesario exponer sus ideas económicas para explicar las relaciones entre derecho y economía. De tales lecciones se tiene noticia por el resumen que realizó José Manuel Piernas Hurtado, ${ }^{10}$ un personaje clave, por cierto, en la formación y en la trayectoria de Costa en relación con la economía. ${ }^{11}$ Las críticas de Giner abarcan dos planos: el concepto de economía y los límites de la política económica. En cuanto al concepto de economía, se plantea refundar esta a partir de las bases filosóficas del organicismo krausista, pero por ahí apenas avanzó. En cambio, resultó mucho más llamativa su propuesta de utilizar el poder del Estado para remediar males de la economía, tales como la cuestión social.

El segundo hito en las críticas españolas a la escuela economista fue la publicación en 1876 de los Estudios económicos y sociales de Gumersindo de Azcárate, libro que recogía trabajos de los años anteriores. Con un lenguaje menos filosófico, más próximo a los economistas, y desde una posición de liberal reformista, marcaba también distancias con el optimismo y abría la puerta a una intervención más amplia del Estado en la vida económica. La

9 G. Franco (1927), p. 13.

10 J. M. ${ }^{a}$ Serrano Sanz (1997), pp. 255 y ss.

11 Véase, por ejemplo, su condición de asesor en los tiempos de la Unión Nacional, a través del epistolario de Bescós. G. J. G. Cheyne (1979), p. 34. 
confianza en que estaba naciendo una nueva escuela de economía, con sensibilidad por la cuestión social pero con los pies asentados en el liberalismo, será duradera entre los krausistas. Eso les permitió mantener una continuada distancia con el historicismo doctrinal y resistir lo que debieron de ser tentaciones del socialismo de cátedra.

En este marco intelectual se inició Joaquín Costa en la economía, pues precisamente en los primeros setenta realizaba sus estudios universitarios y se acercaba de un modo decisivo al krausismo. Desde el principio, tanto sus simpatías personales como sus opciones científicas estuvieron mucho más próximas a Giner, Azcárate y su liberalismo revisado que a los más ortodoxos componentes de la escuela economista. Tan notoria debió de ser la inclinación entonces y más adelante que Piernas Hurtado, al repasar las escuelas españolas de economía a fines de siglo, hablaba de una escuela intermedia entre el liberalismo y el socialismo, una escuela que "aspira a la armonía", en la que situaba a Costa, junto a Giner, Azcárate y él mismo. ${ }^{12}$

El propio Costa se referirá a la disidencia krausista en su discurso de ingreso en la Real Academia de Ciencias Morales y Políticas, cuando haga el elogio de Joaquín M. ${ }^{a}$ Sanromá, quien había mantenido incólume casi en solitario su defensa de los principios de la escuela economista. Entonces dirá: "Como economista, que es la nota dominante del grupo a que perteneció Sanromá, distinguiose por la constancia de sus orígenes y la lealtad guardada a los principios liberales con que había sido marcado casi desde la cuna. Más o menos, casi todos sus compañeros, y de igual modo sus discípulos, han evolucionado, sintiendo entibiarse su fe en los dogmas de la economía ortodoxa: Sanromá no ha transigido; ni siquiera ha sentido desmayos. Ha mantenido enhiesta hasta el último instante 
la bandera de la libertad individual. Cuando en 1876 escribía su Política de taller, había principiado a injerirse en los programas políticos europeos una manera de socialismo que él denominaba "conciliador", el cual, dejando a salvo las libertades industriales, se contentaba con que el Estado interviniera en cierta clase de relaciones entre el capital y el trabajo". ${ }^{13}$ Las fechas y el tema están perfectamente identificadas por Costa: la disidencia de los krausistas con la vieja escuela economista se produjo en torno a 1876 y alrededor de la cuestión social.

Sin embargo, no hubo una ruptura completa porque el liberalismo, con los matices consiguientes, siguió siendo sustrato común de unos y otros, que pudieron así compartir de manera natural un programa de iniciativas a lo largo de la Restauración en torno a la Institución Libre de Enseñanza, creada, como es sabido, en 1876. De ese programa formaba parte la promoción del librecambio, que seguía siendo un ideal para la escuela economista y los ginerianos. He aquí la segunda razón del activismo librecambista de Joaquín Costa, quien participó intensamente, en especial durante los años ochenta, del programa institucionista. Lo hizo hasta el punto de que la Institución marcó, en cierto modo, sus prioridades y buena parte de su plan de trabajo en aquel decenio.

Un decenio, por cierto, buena muestra de aquella su "prodigiosa actividad" de que hablara Gumersindo de Azcárate. ${ }^{14}$ Fueron años en que nuestro hombre ejerció como pasante en un despacho de abogados y era profesor de la Institución Libre de Enseñanza, al tiempo que escribía

13 J. Costa (1901), pp. 297-298. En un sentido estricto, Sanromá no fue el antecesor de Costa puesto que no llegó a tomar posesión de la medalla, ya que murió antes de terminar su discurso. El anterior propietario había sido Manuel Colmeiro, pero Costa prefirió hacer el elogio de Sanromá, algo inusual en la práctica académica, porque no se adquiere la condición de académico sin pronunciar el discurso.

14 G. de Azcárate (1919), p. 20. 
numerosos libros y artículos, dirigía revistas, pronunciaba multitud de discursos y actuaba como verdadero activista en variados frentes, con su pertenencia, nunca testimonial, a diversas asociaciones y su implicación en significados congresos de la época. Un repaso sumario de los hitos principales resulta ilustrativo de tal intensidad y diversidad.

Según el Estudio bibliográfico de Cheyne, entre 1880 y 1889 Costa publicó un total de doce libros, algunos tan importantes como Estudios jurídicos y políticos o La libertad civil y el Congreso de los Jurisconsultos aragoneses. ${ }^{15}$ Dirigió cierto tiempo el Boletín de la Institución Libre de Enseñan$z a$ y la Revista de Geografía Comercial; en ambas publicó, además, numerosos artículos, pero también en otras como la Revista General de Legislación y Jurisprudencia. Intervino activamente en variados congresos: de Agricultura, de Vinicultores, de Pedagogía, Jurídicos o de Geografía. Cheyne, de nuevo, registra nada menos que 32 conferencias o discursos en el decenio. Fue durante algún tiempo alma de la Sociedad de Africanistas y Colonistas y de la Sociedad de Geografía Comercial y miembro notorio de la Sociedad Abolicionista, pero también de la Asociación para la Reforma de los Aranceles de Aduanas. En estas asociaciones compartía casi exclusivamente con miembros de la Institución la tribuna y el correspondiente comité directivo, de modo que es razonable afirmar que su activismo se hallaba estrechamente asociado al institucionismo. Tal ocurría con la propaganda librecambista, como se verá ahora con algún detalle.

\section{COSTA, ACTIVISTA DEL LIBRECAMBIO}

Comenzando por referirnos a la organización. La Asociación para la Reforma de los Aranceles de Aduanas había sido creada en 1859. La propia Asociación publicó una 
"Noticia de su origen y planteamiento, acta de la sesión inaugural y juicio formado por la prensa", que es un completo y valioso testimonio. ${ }^{16}$ De acuerdo con dicho relato, tras la visita que el héroe británico del librecambio, Richard Cobden, hizo a España en 1846 se habría intentado, sin conseguirlo, crear una agrupación de ese tenor. ${ }^{17}$ Diez años más tarde, Laureano Figuerola, Gabriel Rodríguez y Manuel Colmeiro (a quien Costa sucedería en un sentido estricto en la Real Academia de Ciencias Morales y Políticas) contrajeron en el Congreso Internacional sobre Reformas Aduaneras de Bruselas el compromiso de hacerlo y, como un paso intermedio, comenzaron por instituir una Sociedad de Economía Política (en ocasiones se la denominaba Sociedad Libre de Economía Política), el 2 de enero de 1857. De ella salió un breve manifiesto, un proyecto de bases y la convocatoria de un acto el día 23 de abril de 1859 en la Bolsa de Madrid, al que se invitaba a todos los interesados. Según la misma fuente: "El éxito excedió a las esperanzas de todos. Una escogida y numerosa concurrencia que pasaba de cuatrocientas personas llenaba el espacioso local a la hora previamente señalada". ${ }^{18}$ Los fines se hacían explícitos en el artículo $2{ }^{\circ}$ de las bases: "La Asociación tiene por objeto defender y generalizar el conocimiento de la conveniencia de reformar el actual sistema de aduanas, disminuyendo sucesivamente los derechos de importación y esportación [sic], y suprimiendo las prohibiciones, hasta transformar los aranceles establecidos hoy en tarifas puramente fiscales". ${ }^{19}$

La Asociación tuvo un considerable éxito. Consiguió agrupar a un conjunto de personalidades políticas de

16 Asociación para la Reforma de los Aranceles de Aduanas (1859).

17 Sobre Richard Cobden y su viaje a España puede verse E. Lluch (1988).

18 Asociación para la Reforma de los Aranceles de Aduanas (1859), p. 6 .

19 Ibíd., p. 5. 
diversos partidos en torno a la idea; desde moderados como el exministro Luis María Pastor, que fue activo presidente, o el histórico Antonio Alcalá Galiano, hasta demócratas como Castelar, pasando por progresistas como Sagasta o Figuerola y miembros de la Unión Liberal como Cánovas o Colmeiro. Por otra parte, logró crear durante los años sesenta, con mítines y publicaciones, un clima favorable al librecambio, que fue aprovechado cuando las circunstancias políticas lo permitieron. Nos referimos a la reforma de Laureano Figuerola, que fue, de hecho, más fácil de imponer en 1869 porque encontró el terreno abonado gracias al activismo de la Asociación durante el decenio precedente.

El Arancel Figuerola es considerado en historia económica el símbolo máximo del liberalismo en las relaciones exteriores hasta el Plan de Estabilización de 1959. Sin embargo, no fue una solución propia del radicalismo, sino un ejemplo de transacción, en cuanto las rebajas se programaron graduales, tres en un plazo de doce años, para dar tiempo a que los productores se preparasen. Así se establecía en la base quinta del Arancel, que aplazaba por ese tiempo la reducción de los derechos hasta el $15 \%$ ad valorem, en que, con fines estrictamente recaudatorios, se fijaba el máximo. Según la historiografía, habría sido el general Juan Prim, sensible a los intereses industriales, el muñidor de esta solución aceptada por Figuerola, quien, a su vez, era partidario también de un cierto gradualismo aunque por razones doctrinales. ${ }^{20}$

La aprobación del arancel, sin embargo, fue traumática. A una parte significativa de la Asociación, incluidos el presidente Luis M. ${ }^{a}$ Pastor y el secretario Gabriel Rodríguez, los derechos les parecían elevados y el aplazamiento de las rebajas un error, con lo que pronto se mostraron en

20 Sobre L. Figuerola véase A. Costas (1988) y F. Cabrillo (1991). También, E. Fuentes Quintana (dir.) (2001), vol. v. 
contra. Gabriel Rodríguez, que había sido antes subsecretario con Figuerola, encabezó un voto particular contra el proyecto del Gobierno y perdió la votación; años después Costa se refirió en un meeting a ese voto mostrándose de acuerdo con él [29]." En el propio mes de julio en que se aprobó el arancel, la Asociación, en asamblea, se pronunció en contra y a principios de agosto declaraba en un comunicado oficial: "Deber es, por lo tanto, de la Asociación oponerse resueltamente por todos los medios legales a la subsistencia de ese Arancel». La fractura parecía consumada y el mismo Laureano Figuerola dimitió como ministro al día siguiente de la aprobación del arancel, profundamente incómodo con la situación creada. ${ }^{21}$ A pesar de todo, el grupo más radical no fue capaz tampoco de insuflar nueva vida a la Asociación, a la que una año después la prensa veía "en una especie de marasmo". ${ }^{22}$

Tras un paréntesis que duró un decenio, en la primavera de 1879 , comenzaron a aparecer algunas noticias sobre un posible restablecimiento de la Asociación para la Reforma de los Aranceles de Aduanas, ${ }^{23}$ a la sazón liderada por Gabriel Rodríguez. Parecía, en consecuencia, renacer de la mano de una facción, y parte de la prensa especuló con

* Los textos recogidos en esta edición se citan en el presente estudio preliminar por la página de este mismo volumen. ( $N$. del E.).

21 En las Cortes Figuerola había llegado a decir en relación con el voto particular de rechazo al arancel: "debo expresar este íntimo sentimiento de mi alma: cuando yo pronunciaba no, mi corazón y mi cabeza decían sín. Diario de Sesiones del Congreso de los Diputados, 1869, p. 3291.

22 Gaceta de los Caminos de Hierro, 15 de agosto de 1869.

23 En esta segunda etapa el nombre oficial continuó siendo el mismo, según el artículo $1 .^{\circ}$ de los Estatutos aprobados por Real Orden de 27 de mayo de 1879 "Se reconstituye la antigua Sociedad denominada Asociación para la Reforma de los Aranceles de Aduanas. Sin embargo, entre 1881 y 1883 se usaron indistintamente -incluso en publicaciones de la Asociación- ese nombre y otro con una ligera variante, Asociación para la Reforma Liberal de los Aranceles de Aduanas. A partir de la segunda fecha siempre se utilizó el nombre oficial. 
la ruptura definitiva del viejo grupo librecambista, porque en la Junta preparatoria solo estaban los más radicales. Finalmente, el 16 de abril de 1879, se celebró la asamblea fundacional en el Círculo de la Unión Mercantil y se eligió una Junta presidida por el propio Gabriel Rodríguez, con Gumersindo de Azcárate como secretario general, pero Laureano Figuerola fue elegido primer vicepresidente; la reconciliación era un hecho. En enero de 1883, el propio Laureano Figuerola asumió la presidencia y Gabriel Rodríguez pasó a ser vicepresidente. Era más lógico, pues Figuerola era el auténtico decano del grupo y la personalidad más representativa de la escuela economista. Su gestión como ministro en el primer Gobierno del Sexenio había sido, a pesar de todo y en conjunto, sobresaliente: abrió el comercio con el nuevo arancel, creó la peseta como unidad monetaria y reformó en sentido liberal la ordenación de la economía española. En la Restauración fue un respetado político republicano y llegó a presidir la Real Academia de Ciencias Morales y Políticas.

En su segunda etapa la Asociación también fue muy activa desde un principio. Se decidió iniciar de inmediato una campaña en pro de la libertad de comercio con mítines dominicales como en el pasado, comenzando por un tema muy querido por los librecambistas, el problema de las subsistencias y la libre importación de cereales. Hasta los primeros noventa se celebraron múltiples mítines sobre temas variados, desde la petición de libre importación de cereales a la libertad de comercio con las Antillas o el apoyo a tratados de comercio tan significados como el de Gran Bretaña.

Este era el mundo en el que se integró por entonces Joaquín Costa como activista del librecambio y poco puede sorprender, considerando sus evidentes conexiones con el grupo de la Asociación para la Reforma de los Aranceles de Aduanas. Fue en el despacho de abogado de Gabriel Rodríguez donde trabajó como pasante a su llega- 
da a Madrid durante cinco años; con él mantendría una larga y cordial relación. ${ }^{24}$ Laureano Figuerola era hombre tan vinculado a la Institución Libre de Enseñanza, donde Costa ejercía como profesor, que fue su primer rector. El secretario general era Gumersindo de Azcárate, otra destacada figura de la Institución. Asimismo, en la Junta directiva menudearon los nombres vinculados a la Institución, hasta el punto de que puede afirmarse que el papel de los institucionistas en el activismo librecambista fue de primer orden. A todos los recordaría con afecto y respeto en sus discursos de los primeros años del siglo xx, conforme algunos iban desapareciendo, siendo quizá la evocación más emocionada la de Gabriel Rodríguez en 1900. "Algunos de esos hombres - diría - representan un capital de consideración en experiencia y en sabiduría, sin el cual tengo por imposible que España se redima; y ese capital está a punto de ir a pudrirse en el cementerio. Ya uno de ellos, que tanto había capitalizado para España en su cerebro y cuyas sabias lecciones habéis escuchado muchas veces en este mismo sitio (lo nombro por excepción y a título de ejemplo), está agonizando en estos instantes a corta distancia de esta casa: D. Gabriel Rodríguez". ${ }^{25}$

24 Según el testimonio de Antonio Gabriel Rodríguez, quien trabajó con su padre en el despacho desde 1879 y se hizo cargo de él tras la jubilación, "entre otros distinguidos abogados que pasaron en su despacho, figuró D. Joaquín Costa durante cinco años". A. G. Rodríguez (1917), p. 22. Cheyne (1972), p. 102, habla de ocho años, pero el testimonio citado parece irrecusable. Por otra parte, un comentario del propio Costa induce a pensar en los cinco años, pues en carta a Giner de agosto de 1886 le anuncia que dejará la pasantía en el otoño inmediato, porque "no estoy contento con él" [Gabriel Rodríguez]. G. J. G. Cheyne (1983), p. 63. Sus relaciones profesionales continuaron, no obstante, en años sucesivos e incluso se intensificaron en los noventa, cuando Costa volvió a Madrid como notario, según se desprende de la abundante correspondencia conservada en el Archivo Histórico Provincial de Huesca. También siguió la buena relación personal, a pesar del comentario citado, y existen numerosos testimonios de afecto y respeto recíprocos.

25 J. Costa (1900), pp. 280-281. 
Junto a ellos, y en ocasiones confundidos con ellos, aparecían en la Asociación republicanos y miembros de la izquierda liberal, dentro o fuera del fusionismo. En esta segunda etapa los conservadores brillaron por su ausencia, con la excepción de Mariano Carreras y González, quien, en su condición de antiguo miembro de la escuela economista, mantuvo la bandera del librecambio aun siendo parlamentario canovista. De manera que republicanos y liberales avanzados, muchas veces con la Institución como nexo común, conformaron el núcleo intelectual y político de la Asociación para la Reforma de los Aranceles de Aduanas en su segunda etapa. Este fue el mundo de Joaquín Costa en aquellos años.

Además de este componente intelectual y político había en la Asociación otro grupo que provenía del ámbito de los intereses económicos, organizados alrededor del Círculo de la Unión Mercantil. Por entonces dicha asociación era representativa del comercio madrileño más conectado con el progresismo y el republicanismo en lo político y con el librecambismo en lo económico. Su papel en la segunda etapa de la Asociación para la Reforma de los Aranceles de Aduanas fue decisivo. Se convirtió en su sede principal; allí tenían lugar las juntas generales, desde la fundacional de 1879, y allí se reunía casi siempre la Junta directiva. Además hubo en la Junta de manera permanente varios miembros representativos del comercio que provenían del Círculo y las conexiones entre uno y otro grupo eran también muy estrechas y hasta personales. El propio Costa fue hombre cercano al Círculo, ${ }^{26}$ donde pronunció algunas resonantes conferencias, desde "El comercio espa-

26 Y tuvo una intensa vinculación en varios momentos con Miguel Moya, uno de los personajes importantes del Círculo. Aunque más adelante sus relaciones tuvieron altibajos, basta recordar que fue quien organizó el viaje a Madrid en 1908 para hablar en el Congreso contra el proyecto Maura. M. Ciges Aparicio (1930), pp. 203 y ss. 
ñol y la cuestión de África" en 1882 hasta la famosísima "Quién debe gobernar después de la catástrofe nacional" de 1900.

Para ser más concretos, digamos que Joaquín Costa entra en la escena de la Asociación librecambista en junio de 1881, cuando se anuncia en la prensa un meeting para el día 26 de ese mes y figura como posible orador. Un mes antes había pronunciado otro discurso, recogido también más adelante, sobre "La agricultura española y la libertad de comercio" en el Congreso de Agricultores, que debe considerarse, a todos los efectos, como su primer discurso librecambista. En él volvía Costa sobre el tema de los dos primeros mítines de la Asociación para la Reforma de los Aranceles de Aduanas, celebrados en 1879, para reclamar la libre importación de cereales. El éxito de Costa como orador, aunque no definitivo, fue inmediato y la prensa le elogiaba más cálidamente que a otros. "El Sr. Costa con frase galana y correcta, pronuncia un elocuente discurso", diría El Imparcial ${ }^{27}$ en referencia a ese discurso en el Congreso de Agricultores.

El primer meeting de la Asociación para la Reforma de los Aranceles de Aduanas en que participó Costa se celebró en el Teatro de la Zarzuela el 26 de junio de 1881 bajo el lema "Urgencia de la reforma arancelaria", fue presidido por Gabriel Rodríguez y tomaron parte en él, aparte de Costa y el presidente, que abrió la sesión, José M. a Alonso de Beraza, Alberto Aguilera, Laureano Figuerola y Segismundo Moret. Además, un proteccionista espontáneo (el "Sr. Vallés") interrumpió precisamente a Costa y el presidente le concedió la palabra después. El acto dio comienzo a las nueve y media de la noche y, según El Liberal, asistió "numerosísima y distinguida concurrencia", entre la que sobresalían bastantes señoras: "los palcos y las butacas

27 El Imparcial, 19 de mayo de 1881. Igualmente elogiosos se muestran El Liberal y La Iberia. 
ofrecían anoche aspecto brillantísimo. Hasta la aristocracia había mandado allí ilustres damas que dignamente la representaban". Los meetings de diverso orden se habían convertido en actos sociales cada vez más frecuentes y concurridos: "la prensa concede con justicia a estas manifestaciones influencia extraordinaria en la opinión pública; además de la utilidad que revisten las grandes enseñanzas que allí se aprenden, el arte hermosísimo de la oratoria recibe de continuo culto ferviente", señalaba el diario. ${ }^{28}$

El Liberal resumiría así las palabras de Joaquín Costa: "El Sr. Costa en un extenso discurso expuso el cuadro de las maniobras desesperadas de los proteccionistas para buscar auxiliares siendo rechazados en todas partes. Se extendió en consideraciones acerca del tratado con Inglaterra y sus consecuencias". Todavía no había alcanzado el éxito deslumbrante que le llegaría en el próximo, aunque el discurso era acaso más enjundioso que efectista. ${ }^{29}$

Su siguiente intervención tuvo lugar unos meses más tarde en otro meeting celebrado el 8 de enero de 1882 en el Teatro de Apolo con presidencia de Laureano Figuerola. El acto se prolongó de las dos a las seis de la tarde y, junto a Costa y el presidente, intervinieron Reina, Ruiz Castañeda, Cid, Pedregal y Gumersindo de Azcárate. De nuevo asistió una numerosa concurrencia, en el que fue tal vez el momento en que la Asociación parecía más cerca del éxito y redobló sus actividades; cuatro meetings celebró en 1882, el máximo de esta segunda etapa. Era un año singular en la política arancelaria, como se explicará después, y la Asociación estaba en su apogeo. Así lo reflejaba la prensa: "Lo que no ha logrado ninguna empresa con dramas, comedias, óperas y bailes de espectáculo en noches de invierno lo ha conseguido la Sociedad Librecambista con discursos sobre aranceles en una tarde pri-

28 El Liberal, 27 de junio de 1881.

29 Ibíd. 
maveral y hermosa: ver llenos los palcos y butacas del teatro de Apolo", decía El Liberal del 9 de enero. ${ }^{30}$ Y El Globo, por su parte, reflexionaba: ¿ ¿Y todavía habrá quien moteje al pueblo español de frívolo y ligero? El pueblo español que en la tarde de ayer, espléndida tarde, convidaba al paseo o a la merienda en la pradera, fue a encerrarse en el Teatro de Apolo, oscuro y frío como son por la tarde todos los teatros, por el solo gusto de oír a los oradores que en defensa del libre-cambio iban a hacer uso de la palabran. ${ }^{31}$

Ahora sí, el triunfo de Costa fue completo, según señalaba la prensa, que lo destaca sobre los demás oradores. "Usó enseguida de la palabra el Sr. Costa. Es este un joven orador de fácil y elegante palabra, que demuestra gran ilustración en sus discursos y que examina las cuestiones bajo un punto de vista levantado y extenso. Ocupose de el [sic] librecambio en sus relaciones con la política internacional e hizo ver cuánto ha influido el proteccionismo en la actitud que observan con respecto a España muchas de las repúblicas americanas. El orador, interrumpido varias veces en el curso de su peroración por las muestras de aprobación del auditorio, fue saludado al terminar con una salva de aplausos nutrida y prolongada", decía $E l$ Globo al día siguiente. Y El Liberal, que tan parco se había mostrado al hablar de Costa en junio, señalaba ahora: «El discurso que pronunció a continuación el Sr. Costa proporcionó a este joven y elocuentísimo orador un gran triunfo ¡Bien lo merecía! Es un trabajo admirablemente pensado y expuesto con una claridad, con una corrección y con una brillantez extraordinarias". Y unos días más tarde La América señalaba: "El escenario estaba decorado con gran lujo, los oradores hablaron mucho y bien; el público no cesó de aplaudir en toda la tarde. Si estos aplausos los

30 Ibíd., 9 de enero de 1882.

31 El Globo, 9 de enero de 1882. 
reparte la justicia, los mejor librados serán los Sres. Costa, Pedregal y Azcárate». Quizá fue el primer gran éxito de Costa como orador recogido por la prensa.

El caso es que debió de influir también en el acuerdo que tomó la Junta general ordinaria de la Asociación para la Reforma de los Aranceles de Aduanas unos días más tarde, el 29 de enero de 1882, de incorporar a Costa a la Junta directiva de la Asociación. ${ }^{32}$ Y como Costa no asumía los cargos como meros adornos, sino que se implicaba en el trabajo con todas las consecuencias, a pesar de las múltiples obligaciones que acumulaba, participó desde entonces con regularidad en las frecuentes reuniones de la directiva, que a menudo tenían periodicidad mensual, y en las juntas generales. ${ }^{33}$ Asistió asimismo a muchos otros meetings, ocupando su sitio en el escenario como miembro de la dirección, aparte, por supuesto, de los dos adicionales en que intervino en ese año y el siguiente. Aun-

32 El oficio por el que Gabriel Rodríguez, presidente de la Asociación para la Reforma de Aranceles de Aduanas le comunicó a Costa su nombramiento como vocal se encuentra en el Archivo Histórico Provincial de Huesca. Costa/000097/102-2A (8430).

33 Esta era la Junta que había sido elegida en 1881 y a la que se incorporó Costa: presidente: Gabriel Rodríguez; vicepresidentes: Laureano Figuerola, Julián Prats, Segismundo Moret, Bonifacio Ruiz de Velasco, Joaquín María Sanromá, Patricio de Pereda, Manuel Pedregal y Felix Bona; secretario general: Gumersindo de Azcárate; tesorero: Domingo Peña Villarejo; contador: Pedro Ruiz de Velasco; vocales: Alberto Aguilera, Luis Felipe Aguilera, Aguirre, José Luis Albareda, José María Alonso de Beraza, Ignacio Arce Mazón, Ángel Berroeta, Antonio Aura Boronat, Andrés Borrego, Calvo y Muñoz, Mariano Carreras y González, Carvajal, Eduardo Chao, Colás, José Echegaray, Iparena, Rafael María de Labra, Manuel María Llorente, Joaquín López Puigcerver, Cecilio Lora, Manuel Merelo, Cipriano Segundo Montesinos, Justo Pelayo Cuesta, Mario Pérez, Carlos Prats, Prieto y Prieto, Eduardo de la Riva, Pedro Rodríguez, Jacobo Rubio, Juan Ruiz Castañeda, Servando Ruiz Gómez, Sancho, Enrique Serrano Fatigati, Luis Silvela, Francisco Somalo y Luis María Utor; secretarios: Ildefonso Trompeta, Miguel Moya, Manuel Zapatero y Garcia, Juan Alvarado, Gutiérrez Brito, García Alonso, Gómez Ortiz y Joaquín García Soldado. 
que a partir de 1883 pareció dedicar mucho tiempo a la Sociedad de Geografía Comercial no dejó sus obligaciones en la Asociación para la Reforma de los Aranceles de Aduanas mientras estuvo en Madrid siendo reelegido en sucesivas juntas.

Tras el éxito de enero, Costa volvió a intervenir en otro meeting el 21 de mayo del mismo 1882. En esta ocasión se celebró en el Teatro de la Comedia. El meeting, que tenía como lema la "Necesidad de decretar la libre importación de trigo-Urgencia del restablecimiento de la base quinta", estuvo presidido por Figuerola y comenzó a las cuatro de la tarde. Intervinieron además Mariano Carreras y González, Manuel Pedregal, Carbó, Gumersindo de Azcárate, Segismundo Moret y Gabriel Rodríguez, es decir, la flor y nata de la Asociación. Costa habló tras el presidente e introdujo a los oradores, aparte de hacer su propio discurso, destacando de nuevo por su brillantez. "Su discurso admirablemente pensado y dicho con palabra enérgica y elocuentísima fue muy aplaudido", decía El Liberal al día siguiente. ${ }^{34}$ Y La Discusión, por su parte, declaraba: "A la terminación de cada párrafo y de su discurso el Sr. Costa fue calurosamente aplaudido por la concurrencian. 35

El último de los meetings de la Asociación para la Reforma de los Aranceles de Aduanas en que participó Costa tuvo lugar el 23 de junio de 1883 en el Teatro de la Comedia, con el lema "Estado actual de la cuestión arancelaria". Presidía Laureano Figuerola y el acto comenzó a las tres y media de la tarde con la participación de Ruiz Castañeda, Pedregal, Azcárate, Figuerola y Costa. No estaba prevista inicialmente ni anunciada la intervención de Costa, pero Segismundo Moret y Gabriel Rodríguez no pudieron concurrir y, según dijo Costa al comenzar, "para no defraudar tanto al público que honra este acto con su

34 El Liberal, 22 de mayo de 1882.

35 La Discusión, 22 de mayo de 1882. 
asistencia, mis compañeros de Asociación me han instado y el digno Presidente [Figuerola] me ha constreñido a que llene, siquiera materialmente, un paréntesis de 15 minutos y prepare los ánimos para el desenlace». Sin embargo, este discurso resulta ser el más elaborado y original de todos, con una sucesión de "cuentos de aldea" muy bien trabada y extremadamente efectista. De nuevo la prensa destacó el parlamento de Costa, lo divertido que le resultó al público y los aplausos que le dedicaron. Costa era ya un orador consagrado y no solo para pronunciar un discurso preparado con tiempo, sino capaz de brillar en medio de la premura, aunque de la lectura se desprendía claramente que no fue improvisación.

Después de este discurso de 1883, Costa no volvió a intervenir en otros meetings de la Asociación, si bien - COmo se ha indicado- continuó asistiendo a los sucesivos y a las reuniones de la Junta directiva. Se sentía tan identificado con la causa como para defender públicamente a la Asociación si consideraba que era atacada, como hizo en 1884 en el Congreso de Agricultores. ${ }^{36} \mathrm{Y}$ participó activamente en otros congresos sosteniendo las posiciones librecambistas, por ejemplo, en el muy importante Congreso de Vinicultores de 1886 defendiendo los tratados de comercio ambiciosos. ${ }^{37}$

Sin embargo, en poco tiempo la propia organización comenzó a languidecer lentamente y antes de finalizar el siglo desaparecería de escena. De los 23 actos que convocó entre 1879 y 1893, más de la mitad, 14, se celebraron en los cinco primeros años, en 1884 no hubo ninguno y, tras un breve renacimiento en 1885 (con tres meetings,

36 "El Sr. Costa suplica a la presidencia le conceda defender a la Asociación para la Reforma de Aranceles de Aduanas, aludida por el Sr. Abela", decía La República del 27 de mayo de 1884.

37 Curiosamente, Costa figuraba allí inscrito como representante de la Diputación Provincial de Huesca. Ministerio de Fomento (1887), p. 34. 
motivados principalmente por la polémica en torno al proyecto de tratado con Gran Bretaña), el declive se hizo muy marcado.

Costa dejó Madrid en 1888 y regresó en 1894 como notario. Fueron precisamente los años en que se produjo el viraje proteccionista en la Restauración, con la derogación definitiva de la base quinta del Arancel Figuerola en 1890 y la del propio arancel, sustituido desde el 31 de diciembre de 1891 por el que suele denominarse Arancel Cánovas, aunque lo firmara el ministro de Hacienda Juan de la Concha Castañeda. La fuerza del político malagueño y su compromiso entonces con el proteccionismo lo convierten en indudable inspirador del viraje. La negativa francesa a negociar un nuevo tratado de comercio, con que se habrían rebajado los excesos proteccionistas del arancel, dejó intactas unas tarifas exageradas a conciencia para poder ofrecer concesiones sustanciosas. El sesgo proteccionista volvió a dominar en la economía española tras el paréntesis que habían representado Figuerola y los tratados comerciales. ${ }^{38}$

El tiempo del librecambio había pasado y la propia Asociación para la Reforma de los Aranceles de Aduanas se mostró incapaz de reaccionar con eficacia, ni tan siquiera con energía. Sus dos últimos actos fueron un meeting en enero de 1892, algunas semanas después de aprobarse el arancel, y el que resultó ser postrero, celebrado el día de Navidad del año siguiente 1893, en respuesta a otro de carácter proteccionista que había tenido lugar en Bilbao días antes. "Más notable por la calidad que por el número de los concurrentes", decía El Imparcial del día siguiente con no disimulada ironía en su crónica. ${ }^{39}$

De esta suerte, cuando Costa volvió a Madrid en el verano de 1894, la fuerza del librecambio había desapare-

38 Sobre el viraje, véase J. M. ${ }^{a}$ Serrano Sanz (1987).

39 El Imparcial, 26 de diciembre de 1893. 
cido. Pero él siempre mantendría su ideal, como casi todos sus compañeros de la Asociación, al menos en el plano de las teorías. ${ }^{40}$ Así, en 1895 escribía a Gabriel Rodríguez celebrando con entusiasmo un trabajo publicado por este en el que criticaba el entreguismo de Cánovas a los proteccionistas más radicales y recordaba en tono irónico sus antecedentes librecambistas, pues el político malagueño había sido uno de los fundadores de la Asociación para la Reforma de los Aranceles de Aduanas, allá por 1859. "Su monografía de España Moderna, abrumadora para Cánovas que no se atreverá a meterse otra vez en tales libros de caballerías, es un documento importante para la historia económica de España en los últimos treinta y cinco años y le denuncia a usted en la plenitud de sus bríos y de su talento, siendo uno de los trabajos más jugosos y de más intención que ha escrito". ${ }^{41}$

En la práctica, aunque nunca renunciaron explícitamente al librecambio, casi todos acabaron por adaptarse a la nueva realidad, es decir, a aceptar el proteccionismo como un dato difícil de alterar. En su caso, la adaptación fue visible, porque precisamente a partir de los primeros noventa, en coincidencia con el triunfo del proteccionismo, Costa redactó o inspiró diversos programas de gobier-

40 En general, Costa fue bastante consistente en sus ideas a lo largo del tiempo, como ha señalado Gil Novales: "el pensamiento de Costa presenta una admirable consecuencia en todas sus épocas". A. Gil Novales (1965), p. 12.

41 A. G. Rodríguez (1917), p. 134. Se refiere Costa a "La reacción proteccionista en España. La Asociación para la Reforma de Aranceles de Aduanas y D. Antonio Cánovas del Castillo", publicado en La España Moderna en marzo de 1895, año vII, n. ${ }^{\circ}$ Lxxv, pp. 34-56. En el libro de A. G. Rodríguez (1917) se cita erróneamente como aparecido en Revista de España, 15 de mayo de 1894. El texto era un epílogo a una polémica sostenida por G. Rodríguez y A. Cánovas del Castillo. El primero había publicado en 1888 "La reacción proteccionista en España" y el segundo contestó en 1890 con "De cómo he venido yo a ser doctrinalmente proteccionista". Sobre la polémica véase J. M. ${ }^{a}$ Serrano Sanz (2001). 
no. ${ }^{42}$ Entre el discurso del 7 de septiembre de 1892, preparatorio de la constitución de la Cámara Agrícola del Alto Aragón, y el discurso del 12 de febrero de 1906 a la Asamblea municipal republicana en Zaragoza, pasando por los diversos programas ligados al 98, Costa se pronunció sobre la política económica deseable y, cuando lo hizo, el librecambio ni era una prioridad ni estaba siquiera presente.

En los primeros textos se limitó a pedir un acuerdo comercial con Francia para revitalizar la exportación de vinos, algo compartido de forma prácticamente unánime por librecambistas y proteccionistas. En sus declaraciones a El Liberal del 18 de octubre de 1898, que abrieron su campaña tras el Desastre, se limitaba a reclamar "atención intensa y sostenida a los intereses mercantiles de España". ${ }^{43}$ En el Mensaje y programa de la Cámara Agrícola del Alto Aragón de diciembre se pedía "Fomento de la exportación: apertura de nuevos mercados para la producción nacional, hasta asegurarle siquiera dieciocho millones de consumidores más de los que tiene en la Península; y en primer lugar, Méjico y la Plata. Establecimiento de agencias en combinación con las Cámaras españolas en el extranjero y sus sucursales. Rescate del mercado francés para los vinos. Organización de Exposiciones de productos españoles en las Repúblicas americanas cuyos comerciantes sean en gran parte españoles. Fomento de los transportes por ferrocarril y su abaratamiento, haciendo uso de todos los

42 Alfonso Ortí ha destacado la preocupación de Costa por trasladar sus ideas a programas concretos de gobierno: "Quizá ningún otro intelectual, ni siquiera ningún otro político de la España contemporánea, estuvo tan obsesionado con definir un programa de gobierno concretísimo y operativo — directamente "gacetable"- como Joaquín Costa". A. Ortí (1996), p. 501 (cursiva en el original). Sobre el contenido económico de los programas políticos de Joaquín Costa, véase J. M. ${ }^{a}$ Serrano Sanz (2011c).

43 El Liberal, 18 de octubre de 1898. 
medios legales para reducir las tarifas. Reforma de las Ordenanzas de Aduanas". ${ }^{44}$

El programa de la Asamblea Nacional de Productores de Zaragoza aprobado en febrero de 1899 era más detallado, pero en realidad se limitaba a desarrollar los mismos puntos, sin que hubiera, en absoluto, cambio de filosofía. El librecambio seguía estando fuera de la escena: "Fomento de las exportaciones en general.-Celebración de tratados de comercio, en los cuales se obtengan ventajas para la producción nacional.-Organización de Exposiciones de productos nacionales en las Repúblicas americanas cuyos comerciantes sean en gran parte españoles, especialmente Méjico y la Plata. Exposición permanente en los consulados, de los productos españoles de mayor consumo en cada país. Establecimiento de agencias en combinación con las Cámaras de Comercio españolas en el extranjero y sus sucursales.-Excitación a las mismas Cámaras para que creen secciones que se ocupen activa y prácticamente de asuntos agrícolas, de minería y demás de interés para la producción nacional. Rescate del mercado francés para los vinos, dando intervención en los acuerdos y gestiones a los Centros de vinicultores y a las Cámaras agrícolas y de comercio de España. Denuncia inmediata de los tratados de Comercio vigentes, en cuanto a la exportación del corcho, y celebración de otros, especialmente con Méjico y las repúblicas sud-americanas; todo con intervención de las Sociedades defensoras de la producción e industria corcho-taponera.-Convenio con el Gobierno de Portugal, por el cual se grave la exportación del corcho en planchas y cuadrados con un derecho equivalente a aquel con que sea gravado el corcho elaborado procedente de la Península en el país que más lo grave. Mientras ese convenio no se ajuste, imposición de un derecho a dicha 
exportación en las aduanas españolas, fijando su cuantía con audiencia de las mismas nombradas sociedades. Fomento de la marina mercante. Reforma radical de las Ordenanzas de Aduanas y de los Reglamentos congruentes con ellas, en vista de un mayor provecho para el Erario, de las facilidades para el comercio y de la moralidad administrativa". ${ }^{45}$

En 1901 Joaquín Costa evocó sus tiempos librecambistas en las primeras páginas de su discurso de ingreso en la Real Academia de Ciencias Morales y Políticas, al hacer el elogio de Joaquín M. ${ }^{a}$ Sanromá, con quien señalaba líneas de continuidad: "Tres fueron principalmente los empeños a que consagró su actividad como hombre público y por los cuales hubo algo de compañerismo espiritual entre él y su humilde sucesor en este puesto: la abolición de la esclavitud, la libertad de comercio y la reforma colonial». ${ }^{46}$ Y sobre la segunda añade: "todavía me tocó tomar parte en los últimos meetings librecambistas, continuación de los que él había iniciado y mantenido con tanto esplendor en la Sociedad Libre de Economía Política de Madrid y en la Asociación para la Reforma de los Aranceles de Aduanas, con Pastor, con Carballo, con Bona, con Figuerola, con Moret, con Rodríguez, con Azcárate, con Ruiz Gómez, con Trompeta, con Pedregal., ${ }^{47}$

Pocos años después, por una de esas paradojas de la historia, era Segismundo Moret, uno de los oradores que había coincidido con Costa como agitador librecambista, el encargado de remachar el triunfo del proteccionismo, al patrocinar en 1906, como presidente del Consejo, la ley

45 Ibíd., pp. 90-91.

46 J. Costa (1901), p. 294. Sobre Costa y la Real Academia de Ciencias Morales y Políticas, véase E. Fernández Clemente (2006).

47 J. Costa (1901), p. 294-295. En realidad, nunca coincidieron personalmente Costa y Sanromá, según señala más adelante, pues en la segunda época de la Asociación Sanromá no tuvo prácticamente ninguna actividad. 
de Bases arancelarias que lo legitimó. «De los tiempos triunfales del librecambio queda, por desgracia en la realidad lo que a la hora de la tarde queda de aquellas primeras brumas de la mañana, que nos parecieron sonrosadas y encantadoras", ${ }^{48}$ diría Moret entre la añoranza y la impotencia. Costa no llegó a pronunciarse sobre el nuevo arancel.

\section{EL CONTEXTO DE LOS DISCURSOS}

Los cinco discursos aquí reproducidos se pronunciaron entre el 18 de mayo de 1881 y el 24 de junio de 1883 , es decir, en apenas dos años. Dos años que fueron intensos y cruciales desde la perspectiva de la política española y también por lo que hace al comercio exterior y la política comercial.

Políticamente, el bienio se corresponde con el primer Gobierno de Sagasta en la Restauración. Los miembros de la Asociación para la Reforma de los Aranceles de Aduanas acogieron esperanzados al nuevo Gobierno porque consideraban al propio Sagasta un hombre próximo (había estado en la directiva de la Asociación en la primera etapa) y porque había nombrado para Fomento a un miembro de la Junta, José Luis Albareda. En febrero de 1883, entró en Hacienda otro conocido librecambista, Justo Pelayo Cuesta, al tiempo que Albareda fue sustituido por un proteccionista notorio, Germán Gamazo. Sin embargo, más allá de las querellas arancelarias, el Gobierno era la prueba de fuego para conocer si en la Restauración cabía una alternativa avanzada o progresista, junto a la canovista, y si Sagasta era capaz de articular esa opción por medio del fusionismo. 
Desde el punto de vista de la economía se vivían años de expansión, porque el sosiego del nuevo régimen, tras el fin de la guerra carlista, había permitido aprovechar el impulso proveniente de las medidas liberalizadoras del Sexenio. Y eran precisamente el comercio exterior y la política comercial los ejemplos más claros del éxito de aquella liberalización. El comercio había crecido significativamente y con él la recaudación aduanera, y, por esta vía, a finales de los setenta, había ya un consenso bastante amplio sobre las bondades del arancel vigente. Solo una exigua minoría encabezada por Pedro Bosch y Labrús al frente del Fomento de la Producción Española (escindido del Fomento del Trabajo Nacional) reclamaba la vuelta a un severo proteccionismo - al prohibicionismo, le reprocharía el ministro José García Barzanallana- ${ }^{49}$ sin que apenas encontrara seguidores. Los industriales más capaces se estaban apoderando del mercado y expulsaban a los productores artesanos gracias al aprovechamiento del impulso modernizador de un arancel que facilitaba la importación de maquinaria y materias primas. El Gobierno canovista, encantado con el aumento de la recaudación aduanera, rechazó en 1877 una enmienda de Bosch y Labrús para endurecer el arancel, siendo apoyado en su rechazo por significados industriales.

Este amplio consenso era, en realidad, provisional, porque había dos controvertidas cuestiones sobre las que iba a ser necesario decidir en los años inmediatos. Por un lado, la primera rebaja prevista en la base quinta del Arancel Figuerola había sido suspendida en 1875 y su aplicación, o una eventual derogación de la base, seguía sin estar decidida. Por otro, en 1877, se había firmado un convenio comercial con Francia que había hecho aumentar significativamente las exportaciones de vino y, con ello,

49 Diario de Sesiones del Congreso de los Diputados, 28-VI-1877, p. 1323 . 
puso en primer plano la posibilidad de utilizar las rebajas arancelarias para fomentar las exportaciones. Estos dos temas de fondo, más uno coyuntural, el precio del trigo y la libre importación de cereales, protagonizaron los debates de la primera mitad de los ochenta, en los que Joaquín Costa participó activamente. En relación con cada uno de ellos había posturas liberalizadoras y restrictivas articuladas en grupos de presión que organizaron mítines y manifestaciones, enviaron exposiciones a las autoridades y debatieron ampliamente en una prensa alineada también a menudo en dos bandos. Fueron, en suma, unos años en los cuales los debates arancelarios alcanzaron una intensidad especial. Veamos el núcleo de tales controversias para comprender y valorar después las posiciones de Costa.

La base quinta del Arancel Figuerola había sido objeto de críticas de parte de las organizaciones proteccionistas desde el principio, pero en junio de 1875 el Gobierno Canovas se limitó a "suspender" su aplicación, desoyendo las reclamaciones de cuantos pretendían su derogación. Las razones aducidas no eran en absoluto doctrinales, sino que aludían a la situación provocada por la guerra carlista y los desórdenes de años anteriores. Al parecer, fue el general Martínez Campos, a la sazón capitán general de Cataluña, quien influyó en el Gobierno con el argumento de que la suspensión haría ganar adeptos a la causa alfonsina en uno de los focos principales del conflicto. ${ }^{50}$

Sin plazo alguno para reconsiderar la situación, no hubo cambios hasta la llegada del Gobierno fusionista, cuando el ministro de Hacienda Camacho presentó un proyecto de ley en 1881 para que se "alzase» la suspensión. En apariencia, se restituía así al sistema arancelario español un mecanismo básico de la estrategia diseñada por Laureano Figuerola en 1869. Sin embargo, ni el proyecto de Camacho ni la ley resultante tenían mucho que ver con 
la medida original, y por eso cabe hablar de una nueva base quinta. En la ley de 1882, las reducciones de derechos solamente se otorgaban a los países que firmasen con España convenios comerciales. En otras palabras, a las rebajas arancelarias no se las consideraba positivas en sí mismas, sino objeto de negociación. En cambio, en el sistema de Figuerola, el desarme arancelario unilateral era apropiado en sí mismo y no se regateaban las reducciones contenidas en la base, la cual servía únicamente para dar un tiempo de adaptación a la industria. ${ }^{51}$

El proyecto se congeló en Cortes porque, según el ministro Camacho, "no era procedente ponerla en práctica [la rebaja] antes de la terminación del Tratado con Francia". ${ }^{52}$ De forma que, solo cuando hubo concluido este, se discutió y aprobó la ley. Naturalmente, una precaución tan ingenua era difícil que volviese a tener éxito en negociaciones futuras. En cualquier caso, revelaba el papel tan incómodo que desempeñaba la base quinta en un sistema arancelario dominado por las negociaciones, pues anunciaba rebajas a plazo fijo, que dejaban de tener valor como argumento negociador. En la ley resultante se decidió aplicar inmediatamente la primera rebaja de las tres previstas a la tarifa de las naciones convenidas y postergar la segunda y tercera para 1887 y 1892, respectivamente. ${ }^{53}$ Además,

51 Piernas Hurtado lo expresaba de este modo en la época: “De suerte que las rebajas de derechos ordenadas en la Base Quinta eran fijas y absolutas, mientras las ofrecidas por la ley de 1882 son eventuales y puramente relativas; aquellas no exigían más que el transcurso de plazos determinados, estas se subordinan al principio de reciprocidad y requieren, además de los tratados internacionales, una información que debe hacerse en 1886. Difícil es admitir, por tanto, que la ley de 1882 sea la confirmación de la de 1869, y más razón hay para pensar que la deroga, sustituyéndola con una autorización a los gobiernos para celebrar tratados de comercio dentro de ciertas condiciones" (la cursiva es nuestra). J. M. Piernas Hurtado (1885), p. 446.

52 J. F. Camacho (1883), p. 242.

53 En el proyecto inicial las rebajas se hacían en 1885 y 1888. 
antes de llevar a efecto la segunda se obligaba a practicar una información en 1886 para averiguar si convenía "a los intereses generales del país" realizarla entonces o aplazarla a 1892, cuando se uniría a la tercera y última. Finalmente, para que una nueva rebaja tuviese lugar, se establecía la condición de que previamente se consiguiesen compensaciones equivalentes de los otros países. ${ }^{54}$ Era muy difícil que tal planteamiento tuviese futuro, y así sucedió. La base quinta solo se aplicó la primera vez, en 1882, ya que antes de la información de 1886 — que nunca se realizó- el mismo Camacho, otra vez ministro, aplazó la segunda rebaja hasta 1892. Pero en 1890 la base quinta fue definitivamente abolida por el Gobierno liberal-conservador.

Ya se ve que el gran tema del momento eran los acuerdos comerciales y no las rebajas unilaterales, algo que estaba cada vez más claro desde los comienzos mismos de la Restauración. Había sucedido entonces que la filoxera se extendió por Francia, haciendo de ella un país súbitamente deficitario en vino, motivo por el cual en 1877 se firmó un acuerdo comercial que facilitaba las exportaciones españolas. Crecieron estas en poco tiempo y en paralelo lo hicieron el entusiasmo por la viticultura y el prestigio de los acuerdos comerciales.

Durante los ochenta el proceso fue imparable y los vinos acabaron por convertirse en "la cuestión central de la política aduanera española". ${ }^{55}$ Algo lógico, considerando que las ventas de vino común al exterior se habían multiplicado por 7 entre 1875 y 1891, hasta llegar a representar, en el último año, más de un tercio del total de las expor-

54 Moret presentó una propuesta, que fue derrotada, para que las reducciones se aplicasen a las dos columnas, sin vincularse a negociaciones. En 1890 — signo de los tiempos- pedirá que se aplique la base quinta solo a la segunda tarifa.

55 La expresión es del cónsul alemán de la época. A. Gwinner (1892), p. 327. 
taciones españolas. Semejante aumento de la demanda extendió las tierras en cultivo y arrastró la producción hasta convertir a la viticultura en la rama triunfante de la agricultura nacional. España parecía haber encontrado su lugar en la división internacional del trabajo con su especialización vinícola, aunque el hallazgo necesitaba apoyo. El vino era un artículo cuyo comercio tenía problemas en las aduanas de muchos países y de ahí la importancia de abrirle camino por medio de la política de acuerdos. En algunas ocasiones estaba sometido a derechos que trataban de proteger la viticultura local, en otras los obstáculos respondían a un interés fiscal. Además, a veces, las tarifas crecían con la graduación alcohólica del vino (como en Gran Bretaña), lo que perjudicaba a los caldos españoles. Todo ello se podía suavizar mediante pactos ad hoc y así se intentó hacer. Especialmente, porque la dependencia del mercado francés era tan acusada que parecía imperativo diversificar riesgos.

Costa ya había interpretado perfectamente la situación en su primer discurso de 1881. Refiriéndose a él, El Imparcial destacaba cómo se había extendido "en consideraciones para demostrar que el porvenir de la agricultura española se cifra en producir más vinos y menos cereales, porque a ello se presta la naturaleza del terreno y lo aconseja la experiencia de muchos años. Aconseja la celebración de convenios comerciales, especialmente con los Estados-Unidos, para que consuman baratos nuestros caldos y puedan enviarnos en cambio sus cereales; que se renueve el tratado con Francia y que se negocie con Inglaterra la reducción o desaparición de la escala alcohólica». ${ }^{56}$ En adelante, cuando llegue su época de promover programas políticos, el interés por fomentar la viticultura vía tratados será su principal argumento en materia comercial. 
El deseo de aumentar las exportaciones y las posibilidades de utilizar la política arancelaria para conseguirlo fueron una constante desde el comienzo de la Restauración. Con ese fin, en 1877, se creó un arancel de doble columna aprovechando que era preceptivo hacer pequeños ajustes en el Arancel Figuerola para adaptar las valoraciones oficiales a los cambios en los precios. Como primera columna se mantuvieron los derechos del Arancel Figuerola y la segunda columna se obtuvo haciendo leves rebajas en los derechos, para compensar la general caída de los precios. Esta segunda sería la ofrecida a quienes pactasen acuerdos comerciales en España. ${ }^{57}$

La aparición de una segunda columna de derechos, denominada convencional, había tenido lugar en la Europa de mediados de siglo a resultas de la proliferación de acuerdos comerciales. Un país ofrecía a otro rebajas y después las extendía a terceros mediante la cláusula de Nación Más Favorecida, que buscaba evitar las discriminaciones y que todos los países convenidos gozasen de los mismos derechos. La suma de las rebajas constituía la tarifa convencional. Lo peculiar en el arancel español de 1877 es que las reducciones eran ya ofrecidas voluntaria y explícitamente a quien aceptase un pacto, a la par que seguía siendo posible hacer rebajas adicionales en el curso de negociaciones singulares. ${ }^{58}$

57 Sobre estas cuestiones, véase J. M. ${ }^{a}$ Serrano Sanz (1987).

58 "Por una serie de tratados comerciales negociados con las principales potencias europeas se logró atenuar la extrema severidad del sistema arancelario francés, y la conclusión del Tratado con Inglaterra en 1860 fue seguida pocos años después por tratados similares con Bélgica, Holanda, España, Portugal, Suiza, Suecia y el Zollverein alemán. Todos estos tratados contenían la cláusula de nación más favorecida, con lo cual cualquier ventaja concedida a una de ellas era automáticamente extendida a las demás. Así fue establecido en la mayor parte de Europa un régimen fiscal suave, señalado por moderados derechos aduaneros y ausencia de prohibiciones, y sus efectos pudieron ser observados en la notable expansión del comercio europeo entre los años 1860 y 1880". A. Birnie (1965), pp. 96-97. 
Sobre la base de este arancel se desplegó una gran actividad en la firma de convenios. De entre ellos, destacaron los de Francia, Bélgica y Austria-Hungría, tanto por la importancia de los socios comerciales como por haberse pactado reducciones adicionales en la segunda tarifa. Sin embargo, el máximo desarrollo de la política de tratados de comercio llegó con los años ochenta. Los fusionistas continuaron con la idea de que el arancel era primordialmente un instrumento de negociación de concesiones recíprocas $\mathrm{y}$, abandonando prevenciones de años precedentes, la llevaron a su máximo desarrollo. Hasta mediados del decenio también los liberal-conservadores compartieron su criterio, como demuestra el hecho de que fueron los responsables en 1885 de la extensión del trato de Nación Más Favorecida a Gran Bretaña, la más negativa de las concesiones posibles, a juicio de los proteccionistas.

Con todo, el tratado que marcó este período fue el firmado con Francia el 6 de febrero de 1882, tanto por la especial significación del país vecino en nuestro comercio cuanto por la amplitud de las concesiones intercambiadas. Fue, sin duda, el punto de referencia del sistema arancelario español del período. El vino continuó siendo el asunto crucial de ese acuerdo, porque España no pudo desprenderse en todo el decenio de su dependencia del mercado francés, a pesar de que la preocupación por encontrar nuevos mercados fue una constante de la política comercial española. En algunos casos por falta de capacidad de compra del mercado, como en América del Sur; en otros, por la escasa costumbre de tomar el vino, como en Inglaterra y los países nórdicos, el esfuerzo de diversificación fracasó. ${ }^{59}$ $\mathrm{Y}$ aunque el vino es el único artículo que aparece especí-

59 Refiriéndose al caso inglés dice Gwinner: "Fue un error, más tarde confesado, de los librecambistas españoles el de creer que el pueblo inglés haría un gran consumo de vino tinto español a buen precio". A. Gwinner (1892), p. 277. 
ficamente mencionado en el articulado de casi todos los tratados de comercio de los años ochenta, ${ }^{60}$ Francia siguió siendo el comprador de entre un 70 y un $80 \%$ del vino español exportado. De ahí las consecuencias desastrosas de no poder renovar el tratado con Francia a su vencimiento, en 1892.

En conexión con la cuestión de los tratados comerciales, otros asuntos que estuvieron también en el primer plano de los debates arancelarios en los primeros ochenta y que fueron objeto de tomas de posición por parte de Costa fueron las denominadas "compensaciones" y el comercio colonial. Con la premisa de que los tratados beneficiaban a la agricultura y perjudicaban a la industria, los políticos, en general, y los fusionistas en el Gobierno, en particular, se mostraron dispuestos a ofrecer compensaciones a los grupos de presión industriales a cambio de su aceptación de los tratados. Los canales de compensación elegidos fueron dos: privilegios en el comercio colonial y reducción de gravámenes en las primeras materias.

Los grupos de interés venían pidiendo desde tiempo atrás un trato de favor para los productos peninsulares en el comercio ultramarino. El reto consistía en organizar un verdadero sistema de comercio colonial, que debía concluir en una completa integración arancelaria al objeto de aprovechar la teórica complementariedad de las producciones de la metrópoli y las colonias. Ese era el objetivo último de las dos leyes aprobadas en junio y julio de 1882 para regular el comercio colonial, si bien la necesidad de mantener la recaudación aduanera y el peso de intereses azucareros peninsulares impuso un período transitorio de diez años hasta alcanzar el desarme pleno.

60 Así ocurría, entre otros, en los tratados con Venezuela, Suecia y Noruega, Suiza, Alemania, Portugal, Países Bajos, Siam y, por supuesto, Francia y Gran Bretaña; véase J. M. ${ }^{a}$ Serrano Sanz (1987), pp. 47 y ss. 
En cuanto a las primeras materias, una ley de 1883 aprobó una disminución radical de sus derechos. En el proyecto el ministro Camacho había explicado que el origen de la norma era una petición elevada por la industria sedera valenciana tras el tratado con Francia, y que considerando que la necesidad no era una cuestión aislada, generalizó la rebaja a otras primeras materias de la industria. ${ }^{61}$ La idea de compensación al sector manufacturero era explícita: "Este proyecto es la compensación que la justicia y la equidad aconsejan otorgar a las industrias manufactureras, para las cuales la protección arancelaria ha disminuido, con las reducciones de derechos realizadas por el Tratado de comercio con Francia y al aplicarse la Base quinta del Arancel". ${ }^{62}$ Tal justificación daba por hecho que el desarme unilateral era negativo para la economía española, en oposición al espíritu de Figuerola, y fue objeto de críticas por ello en los meetings de la Asociación. ${ }^{63}$ Además, el concepto de primeras materias era más confuso de lo que parecía, pues muchos productos de la industria eran primeras materias para la agricultura, de manera que la ley discriminaba a esta última; esa sería una de las críticas más constantes de Costa, como más adelante veremos.

El último de los grandes temas que estuvo en los debates arancelarios de los primeros ochenta fue el del cereal, otro tema recurrente en Costa. La sequía de 1878-80 había dado como resultado malas cosechas y una elevación del precio del trigo, que pasó de 20,39 pts./Qm en 1877 a 26,67

61 J.F. Camacho (1883), p. 276.

62 Ibíd.

63 "Este Arancel se aplicó a todos los países del mundo, sin exigir nada a cambio, porque el Sr. Figuerola comprendió muy bien que las rebajas que nosotros hacíamos eran ya por sí mismas un gran beneficio para el país y que no debíamos perder este beneficio por el hecho de que no quisieran hacer análogas rebajas las extranjeras", decía Gabriel Rodríguez en 1884 en un mitin de la Asociación para la Reforma de los Aranceles de Aduanas. Véase A. G. Rodríguez (1917), p. 429. 
en 1880. La Asociación dedicó los dos primeros mítines de la segunda etapa, en junio y octubre de 1879, a pedir que se autorizase la libre entrada de cereales. Paradójicamente, en el mismo año de 1879, se habían elevado tarifas agrarias en el Imperio alemán, como respuesta a las ingentes llegadas a Europa del trigo barato de América y otras procedencias gracias a la mejora en los medios de transporte. Los precios del cereal se hundieron en el viejo continente y terminaron por bajar también en España, hasta 19,22 pesetas en 1885, declive que continuó en los años siguientes. Para atajarlo, a principios de los noventa, se intensificaría finalmente en España la protección arancelaria.

\section{SOBRE EL CONTENIDO DE LOS DISCURSOS}

"Costa poseía un don verbal sobresaliente. Hallaba con naturalidad los vocablos significativos y justos", escribió un orador tan excepcional como Manuel Azaña. ${ }^{64} \mathrm{Y}$ otro de esos españoles singulares que también brillaba por su elocuencia, José Ortega y Gasset, decía en una emocionada evocación de 1911: "Tenía su palabra en privado como en público esa afluencia tranquila, uniforme y solemne que llevan en su cauce los grandes ríos. Su torso erguido y poderoso seguía ágilmente el ritmo de sus ideas". ${ }^{65}$ Pocos testimonios tan excepcionalmente valiosos podrían presentarse sobre la calidad oratoria de Joaquín Costa, de la cual sus cinco discursos librecambistas son un claro ejemplo. ${ }^{66}$

64 M. Azaña (2007), vol. 2, p. 290.

65 J. Ortega y Gasset (2007), tomo viI, p. 216.

66 Los testimonios podrían multiplicarse. Así, Azcárate decía que Costa era "un orador en toda la extensión de la palabra". G. de Azcárate (1919), p. 27. Altamira, citado por Azcárate, "opinaba que el verbo de Costa era siempre un verbo caliente, un verbo en el cual la palabra parecía chispear y a veces como golpear a las gentes, arrojando los conceptos como quien arroja proyectiles, para despertar a las inteligencias dor- 
Los discursos tienen interés desde la perspectiva del estudio de sus ideas, es decir, desde la óptica costista, pero también desde el análisis de las polémicas entre librecambistas y proteccionistas. Son variados por las cuestiones examinadas y por la construcción singular de cada pieza oratoria; Costa no repetía argumentos y tampoco reiteraba la forma de presentarlos. En general, no se ocupaba directamente y con detalle de los aspectos concretos y coyunturales, sino que tendía a trascenderlos y darles un tratamiento más amplio. En sus discursos siempre hay un hilo conductor, del que se desprenden sus ideas sobre comercio y política comercial. Son ideas, por cierto, bastante elaboradas, de las que a continuación nos ocupamos.

Tres son los grandes temas que Joaquín Costa aborda en sus discursos librecambistas. Primero, la defensa del librecambio a partir de tres argumentos clásicos: el abaratamiento de los productos que aumenta los niveles de vida, la mejora en la especialización de la economía que estimula el crecimiento y las injusticias derivadas de la redistribución de la renta que causa el proteccionismo. El segundo tema se refiere a la necesidad para España de aumentar su comercio exterior como signo de gran potencia y las implicaciones geoestratégicas de las relaciones comerciales. El tercero gira en torno a la estrategia de política comercial más adecuada para alcanzar la libertad completa de comercio, que era su ideal. Además desliza aquí y allá opiniones sobre la política y la sociedad españolas que años después se convertirán en tópicos del pensamiento costista.

midas". Y añadía otra cualidad expresiva de Costa: "escribía y hablaba de igual manera [...] no había apenas diferencias entre el escritor y el orador». G. de Azcárate (1919), p. 30. Incluso alguien con tan escasas simpatías por Costa como Juan Moneva y Puyol reconocía sus cualidades oratorias: "el Sr. Costa es un retórico que sabe manejar todos los artificios de la elocución para construir párrafos de bella ideología aun cuando trate de materia tan ruda y árida cual el Derecho consuetudinario de la Montaña aragonesa". J. Moneva y Puyol (1899), p. 199. 
Empezaremos por los argumentos en favor del librecambio. De los tres argumentos en favor del librecambio, Costa presta especial atención a los efectos negativos que tiene la protección para la equidad, en cuanto un arancel altera la distribución de la renta a partir de una decisión política, y en ese sentido arbitraria, favoreciendo a unos colectivos y perjudicando a otros. No era el argumento más manido en aquel tiempo, cuando la baratura en los precios y la mejora en la especialización a través de la mayor competencia eran vistas como las grandes virtudes del librecambio. Así puede comprobarse en los manuales de economía de orientación librecambista, como el de Colmeiro, en los discursos de la Asociación para la Reforma de los Aranceles de Aduanas o en los debates parlamentarios. Sin embargo, en la literatura actual se da gran importancia a los trastornos distributivos provocados por el proteccionismo, que, además de influir negativamente sobre la equidad, reducen el crecimiento, al promover la utilización de recursos en la creación y la actividad de grupos de presión cuyo único objetivo es la búsqueda de rentas. En otras palabras, el proteccionismo alienta la obtención de ingresos que no provienen de mejoras en la eficiencia, sino de la capacidad de influencia política. Aunque este tipo de razonamiento como tal, en términos de búsqueda de rentas, no podía estar en Costa, sí es destacable que él viera en las cuestiones distributivas un problema importante derivado del proteccionismo. Por esta razón resulta apropiado comenzar por el argumento distributivo, que además, en boca de Costa, se convierte en un valioso recurso oratorio. Así, puede trasladarlo fácilmente al ámbito de la política y tildar a la protección de "injusticia", puede sacar partido a la perspectiva sectorial, que tanto le interesaba, e identificar beneficiados y perjudicados, y los grupos de interés tras las luchas arancelarias. Por otro lado, puede generalizar el problema de la traslación de la carga impositiva del arancel hacia el conjunto de la fisca- 
lidad y hablar de quién paga verdaderamente los impuestos en España y de si hay o no equidad en el reparto de la carga tributaria para el sostenimiento del Estado. Se trata de argumentos que no son meramente intuitivos y requieren cierto dominio de conceptos económicos que Costa demuestra manejar con soltura.

En su primer discurso de la Asociación para la Reforma de los Aranceles de Aduanas, el de junio de 1881, desarrolló estos argumentos en un párrafo bien representativo de sus ideas y también estilo: "el primer cargo que tengo que formular contra la protección aduanera es que con el actual régimen arancelario los labradores, a pesar de constituir en España mayoría, y de regir una Constitución que hace de igual condición a todos los españoles, pagan impuestos de que los industriales están exentos. Los industriales beben nuestro vino, no ya al precio a que lo da la Naturaleza, sino más barato, porque nos cierran los mercados extranjeros, y, por tanto, restringen la demanda; en cambio, nos obligan a vestirnos de sus telas, no ya al precio a que pueden producirse, sino más caras, porque cierran nuestro mercado a los tejidos extranjeros, que aumentarían la oferta; por manera que los agricultores pagamos impuestos que no satisfacen los industriales, sea al Estado, en forma de derechos de aduanas, sea al fabricante español, en forma de sobreprecio, sea a los contrabandistas o a las sociedades de seguros de contrabando, en forma de prima. Y por Dios, señores, es bueno que resulte ahora que los labradores somos pecheros de los fabricantes; que medio siglo después de haberse proclamado, junto con otras libertades y con otros derechos, la igualdad tributaria, resulte que los labradores pagamos dos contribuciones que apenas alcanzan a ellos; una por efecto de esa carestía artificial, en forma de sobreprecio, y otra directa, para mantener carabineros y cuerpo pericial en las fronteras; carabineros y cuerpo pericial que, al cerrar las puertas de España a los tejidos ingleses, cierran juntamente las puer- 
tas de Inglaterra a nuestros productos agrícolas, y cuyas bayonetas obran por esto a modo de lanceta que está picando constantemente las venas de 16000000 de españoles, para trasvasar su sangre en las venas de unos cuantos capitalistas, señores feudales del algodón y de la lana. (Grandes aplausos). A esto los proteccionistas lo llaman patriotismo, lo llaman industria nacional" [30-31]. Están aquí muchos de sus temas recurrentes: la protección de la industria se hace a costa de la agricultura y no hay igualdad real ante la ley por diferencias en la fiscalidad.

Costa se presentaba en los meetings a menudo como agricultor o, cuando menos, como representante de los agricultores, cuya perspectiva adoptaba. "Nosotros los labradores", decía en 1882 [84], después de hablar de "lo simpático que me es un tema que tan de cerca toca a la agricultura, cuya voz quisiera llevar a aquí" [80]. Todo ello tras haber señalado en 1881 que "la industria por excelencia nacional de los españoles [...] [es] la industria agrícola" [27]. No es que cifrara solo en la agricultura las posibilidades de desarrollo de la economía española, pero reconocía el abrumador peso del sector agrario en la economía y también en la sociedad de su época, al tiempo que le irritaba la profunda injusticia derivada de la tributación y el proteccionismo.

Consideraba incluso que los agravios a la agricultura no eran cosa del día sino seculares: "es triste sino el sino de la agricultura española; desde los primeros siglos de la Edad Media hasta la centuria presente, ha sido víctima de la ganadería: por favorecer a los ganados mesteños, el legislador oprimía cruelmente a los labradores. La emancipación estaba a punto de ser un hecho, cuando he aquí que surge de pronto enfrente de ella un nuevo enemigo, la industria de tejidos, que, como cosa de lana, naturalmente ha heredado las tradiciones de privilegio y los instintos belicosos de los antiguos ganaderos; y la agricultura, obligada a combatir esta nueva Mesta industrial, no 
menos temible, porque no es menos desleal, ni menos egoísta, ni más escrupulosa que la antigua, descuelga las armas con que triunfó del Honrado Concejo, armas, aunque antiguas, no viejas ni mohosas, sino dotadas de una juventud eterna, porque esas armas son la igualdad y la justicia enfrente del egoísmo, de la expoliación y del privilegio" [5]. La equiparación de la industria proteccionista con la Mesta era otro argumento favorito de Costa, cuya animadversión a la antigua organización de ganaderos era patente: "QQué es mesta? Sacar de esa bolsa y meter en esta. ¡Ahí tenéis la "vera effigies" del proteccionismo!» [94], decía en 1882.

No solo el proteccionismo preocupaba a Costa como determinante del tratamiento desigual a la agricultura y la industria, sino el conjunto de la fiscalidad española. Lo demuestra cuando, también en 1882, destaca: "nosotros, labradores, que sostenemos el presupuesto de la nación (pues el impuesto que satisfacen las industrias protegidas apenas alcanza para pagar su escasa soldada a los carabineros)" [89]. Y añade: "Somos iguales ante la Constitución del Estado, y queremos ser también iguales ante la ley fiscal" [86-87]. Un año antes, tras usar el mismo argumento, ilustró con algunas cifras lo que interpretaba como discriminaciones fiscales, para mostrar que los industriales pagaban menos impuestos que los agricultores, los comerciantes y hasta los abogados [23].

Ciertamente, hoy la historiografía sobre la hacienda española decimonónica da la razón a Costa, porque con cifras más refinadas ha quedado claro que la agricultura estuvo gravada muy por encima de la industria (Comín, 1988; Vallejo, 2001). En cambio, no fue tan acertada su visión del conjunto de la fiscalidad española, que Costa creía excesiva, situando los impuestos pagados por los españoles muy por encima de los que satisfacían otros europeos. "Fuera de Austria, somos el pueblo más recargado de tributos", afirmaba en 1881 [6]. Pero esta aprecia- 
ción, más que una realidad, reflejaba la típica visión de economista liberal de la época, en que Costa encajaba. Precisamente, uno de los problemas de la hacienda española del momento radicó en la escasez de recursos por comparación a otros países. Escasez que provenía, es cierto, de los menguados gravámenes sobre la industria y ciertas rentas, pero también del desigual reparto de la carga entre los agricultores, en perjuicio de los más modestos. En definitiva, era una consecuencia de no haber retocado adecuadamente el sistema impositivo liberal, diseñado en 1845 por Alejandro Mon y Ramón de Santillán, y cuya modificación durante el Sexenio fracasó. Paradójicamente, la primera reforma efectiva de la hacienda la haría en 1899 Raimundo Fernández Villaverde, desde el propio sistema de la Restauración, y con Costa enfrentado ya en la arena política.

La visión que Costa tenía de la economía como un conjunto donde dominaban las interrelaciones sectoriales o entre agentes la explotó a fondo para evidenciar las contradicciones del proteccionismo y, muy en particular, en la polémica sobre las reducciones arancelarias a las primeras materias. La pretensión de los industriales proteccionistas de conseguir compensaciones a las modestas rebajas del tratado con Francia de 1882 mediante una reducción de los derechos sobre las llamadas materias primas escandalizaba a Costa. "[...] voy a fijar en términos precisos el valor de estos dos vocablos: materias primeras y productos elaborados. Vosotros convendréis conmigo en que estos dos conceptos son puramente relativos: lo que para la agricultura son productos, el algodón, el lino, el cáñamo, la seda, la lana, las pieles, la madera, el añil, el trigo, el vino, el aceite, para la industria fabril es primera materia; y viceversa, lo que para la agricultura es materia primera, las máquinas y las herramientas, los materiales de construcción, los medios de trasporte, los vestidos y el calzado, los abonos artificiales, muchos productos químicos, la barrile- 
ría, la botillería, etc., es producto para la industria. Puede decirse en cierto sentido, por más que parezca paradoja, que la misión de la agricultura se cifra toda entera en producir primeras materias para la industria, y que toda la misión de la industria se reduce a producir primeras materias para la agricultura" [81]. De ahí deducía Costa que solo podía haber dos sistemas racionales y al tiempo justos: el proteccionismo integral o el librecambio absoluto. Pero no era eso lo que defendían los proteccionistas, y así lo explicaba: "Nosotros somos librecambistas como productores y como consumidores: ellos son librecambistas como consumidores, y como productores, proteccionistas: son librecambistas para el algodón en rama y para la seda en rama porque les conviene comprarlos baratos, y proteccionistas para las telas de seda y de algodón porque les conviene venderlas caras: son librecambistas para las lanas y las hilazas de lino y de cáñamo porque les conviene, y proteccionistas para los tejidos de hilo y de lana porque no les conviene: son librecambistas para el petróleo en bruto porque les conviene, y proteccionistas para el petróleo refinado porque no les conviene; son proteccionistas para la salida de corcho elaborado porque les conviene, y proteccionistas para la entrada del corcho elaborado porque no les conviene; son librecambistas para la maquinaria y para el carbón mineral porque les conviene, y proteccionistas para el hierro con que esas máquinas se fabrican y para los productos que mediante el carbón se elaboran porque no les conviene; son librecambistas para todas sus primeras materias, pagando tan solo por ellas el 4 por 100 , y proteccionistas para los géneros elaborados con ellas, haciéndonos pagar por ellas ocho veces eso, el 32 por 100; que de esta suerte, esa flamante escuela que se viene entre gemidos y amenazas invocando la justicia, pide, con efecto, justicia, pero no por su casa, siendo proteccionista para sí y librecambista para el prójimo, y ostentando dos caras, como el Jano de la mitología antigua, una que mira al cielo 
de la libertad, otra que mira al infierno de la protección y del despotismo" [85]. En resumen, y como había dicho en 1881, el problema mercantil ya no era como antes, un problema entre productores y consumidores, sino entre diversas clases de productores.

Los dos argumentos más frecuentes en quienes defendían el librecambio por aquel tiempo - ya se ha dichoeran la baratura que producía el comercio libre en todos los productos y el crecimiento económico superior que cabía esperar de una economía más eficiente por estar intensamente especializada. No los desconocía Costa, que también los empleó con igual claridad y efectismo, aunque con menor frecuencia.

Respecto al primero decía en 1882: “Llamar antipatriota al pobre pueblo porque opta por sacar de su jornal la mayor cantidad posible de pan, de carbón, de telas, de luz y de ventilación en su vivienda! [...] no condenéis al pueblo porque quiere servirse de esa máquina de abaratar los productos, de multiplicar el bienestar, de fabricar oro, que se llama el librecambion [46]. El argumento de la reducción de la restricción presupuestaria o del aumento del bienestar con el librecambio apenas se puede explicar más elocuentemente. Sin embargo, en términos históricos, la baratura del trigo había sido un factor determinante en el éxito del librecambio y a él se refirió varias veces Costa. ${ }^{67}$ Los

67 En aquel tiempo abaratar el precio de los cereales, o del trigo en particular, era tanto como rebajar el precio de las subsistencias y, por ese motivo, una cuestión decisiva para la política económica. Además, el primer gran éxito del librecambismo en Europa había sido la liberalización del comercio de granos en Gran Bretaña a mediados de los cuarenta, mitificado por los librecambistas continentales y españoles en particular. Pero desde el Trienio, las limitaciones a la importación de cereales eran también una medida política para contentar a un sector importante de los agricultores, y en esa tensión se vivió a lo largo del siglo. La transformación de la agricultura parecía la única forma de hacer compatible el mantenimiento de la población rural y el abaratamiento de las subsistencias, como vio claramente Costa y también los demás librecambistas. 
cereales "son la mercancía más liberal que yo conozco. Ellos, los cereales, han constituido siempre el argumento más elocuente y más sólido que se haya formulado jamás en favor del librecambio; tan elocuente que, al oírlo, o mejor dicho, al sentirlo, los más convencidos partidarios de la protección han depuesto las armas y se han declarado temporalmente librecambistas. Siempre que el país se ha visto afligido por alguna grave crisis alimenticia, en 1847 , en 1856 , en 1868, la primera medida, acaso la única medida que ha discurrido la opinión y que ha adoptado el Gobierno, ha sido declarar de libre introducción los cereales extranjeros; y es, señores, que el hambre es un género esencialmente proteccionista, y naturalmente, para matarla, había que recurrir a procedimientos de libre-cambio" [75-76].

La cuestión del trigo aparecía tanto en relación con el nivel de vida y los precios como en el otro argumento tradicional del librecambismo, la capacidad de crecimiento de un país derivada de su especialización productiva. Es conocida la postura radical de Costa frente al cultivo de los cereales, porque consideraba que representaban una rémora para las posibilidades de la agricultura española y, en general, para el crecimiento del conjunto de la economía. ${ }^{68}$ Todo eso era para él un problema de especialización productiva y el comercio exterior era la piedra de toque. Ya en su primer discurso librecambista, el que pronunció en mayo de 1881 en el Congreso de Agricultores, señaló: "proteger el trigo sería fomentar un cultivo que está

68 El argumento estaba presente en otros pensadores librecambistas como Laureano Figuerola, quien ya en las conferencias celebradas por la Asociación para la Reforma de los Aranceles de Aduanas en el Ateneo de Madrid durante el curso 1862-63 había afirmado: "nuestra patria no es tan a propósito para la producción de cereales como generalmente se cree; tenemos tierras mucho más adecuadas para la viña, para los olivos y para una infinidad de caldos que para el trigo". L. Figuerola (1863), p. 198. 
condenado necesariamente a desaparecer, a expensas de otros dos o tres que están llamados a enseñorearse de nuestra agricultura; sería fomentar lo que representa la ruina y la miseria de España, a expensas de lo que representa su riqueza y su porvenir" [11].

La cuestión acabaría por convertirse en uno de los grandes asuntos del Costa activista en tiempos de la política hidráulica, pero, sobre todo, en pilar de un cierto costismo, capaz de reducir la figura del pensador al tópico de pensador limitado a una coyuntura, que, caracterizada por el atraso agrario, le lleva a remachar la necesidad de un cambio. Así expuesto, el pensamiento de Costa podría tacharse de efímero, incluso de poco original, pues en la crisis cerealícola de los años ochenta la modernización de la agricultura basada en una mejora técnica de los cultivos con mayor empleo de maquinaria y abonos, con selección de semillas, enseñanza agrícola, regadíos, combate a las plagas y otros remedios está presente de continuo hasta en la Gaceta de Madrid. ${ }^{69}$ Bajo la exclusiva óptica de ser un impulsor de las transformaciones agrarias, Costa no resiste el paso del siglo xx. Sin embargo, dándole al comercio internacional la dimensión que él mismo le daba en estos textos, como un factor necesario para estimular la especialización y poner a prueba la productividad relativa de un sector o un país, la perspectiva cambia por completo. En este Costa, el agrarismo queda lejos de ser un fin obsesivo y hasta irracional. De ahí la importancia que tiene, en nuestra opinión, ensalzar el papel del comercio exterior en el pensamiento costiano. ${ }^{70}$

En cuanto a la reorientación productiva, en la coyuntura específica de los discursos, Costa la ve dominada en

69 Un repaso de todas esas medidas puede verse en J. M. ${ }^{a}$ Serrano Sanz (1987), pp. 100 y ss.

70 Sobre el pensamiento agrario de Costa, C. Gómez Benito y A. Ortí (1996). 
primer término, como es bien conocido, por la expansión de la viticultura y los pastos a costa del cereal. Es lógico, porque la del vino era una brillante realidad a principios de los ochenta, que iría a más conforme avanzara el decenio. Y para estimular esa reorientación se consideraba decisiva la desaparición del proteccionismo triguero, que estaba manteniendo artificialmente un cultivo inviable en situación de competencia en muchas de las tierras hacia las que se había extendido. Incluso para Castilla, donde él veía el epicentro del problema triguero, predicaba: "Hablando en términos generales, la agricultura castellana debe, a juicio mío, considerar las tierras que actualmente destina al cultivo de granos en cuatro partes: sembrar la una de trigo y cebada, alternando con veza y algarroba; ir plantando de vino otra cuarta parte, y adebesar las dos restantes a fin de obtener pastos naturales si no se atreve a convertirlas desde luego y de una vez en prados artificiales de secano o de regadio, según las circunstancias" [12] (cursiva en el original).

Esta su crítica al proteccionismo triguero como base de una nueva agricultura convierte a Costa en precedente de ilustres economistas de comienzos del siglo xx, como Antonio Flores de Lemus, según recordó hace algunos años Juan Velarde Fuertes. ${ }^{71}$ Le convierte también en inspirador de algunos regeneracionistas castellanos, como el notario de Frómista Julio Senador, quien tiempo después afirmaba: "Creemos que el que, por la supresión del Arancel les imposibilitara [a los agricultores] de continuar labrando en la forma actual, sería para ellos un amigo muy útil. Ese trigo les hunde. Ahí está nuestro "peligro amarillo". El porvenir es del viñedo, del bosque y del ganado". ${ }^{72}$

71 J. Velarde Fuertes (1961). Véanse además las Obras de A. Flores de Lemus (2010).

72 J. Senador (1920), p. 245. Sobre J. Senador y la influencia de Joaquín Costa sobre él, véase F. Estapé Rodríguez (1989). 
El retroceso del cereal era también, sostenía Costa, desandar el erróneo camino emprendido tras la desamortización. Según sus palabras, "retroceder aquí es adelantar: hay que dar al trigo únicamente lo que es del trigo y restituir al monte y a los pastos lo suyo, que les tienen injustamente usurpado los cereales" [13]. Aquí el Costa modernizador de la agricultura se daba la mano con el defensor de la costumbre: una ley positiva había violentado normas consuetudinarias sobre la propiedad comunal y tradiciones decantadas, hasta conducir a la sociedad a un callejón sin salida. Años más tarde se ocuparía a fondo de esta cuestión, pero ya estaba ahí el embrión, mostrando una vez más la coherencia lógica y temporal de las ideas de Costa.

La modernización de la agricultura, para hacerla sostenible en términos de competencia internacional, no solo exigía reorientar los cultivos y desandar el camino de la desamortización, sino emprender un conjunto de reformas que hicieran factible la producción estable y el comercio. "[...] hace falta, digo, un vasto sistema de obras públicas $[\ldots .$.$] ¿hay que combatir la sequía? Las obras públi-$ cas habrán de ser canales de riego. ¿Hay que hacer fecundo el librecambio que pedimos para que a los cereales sustituyan la viña, los frutales y la ganadería, esto es, granjerías y cultivos que produzcan artículos de exportación? Pues las obras habrán de ser vías de comunicación" [7677]. Sus propuestas no se limitaban a grandes proyectos generales, pues también se refería a medidas específicas. Por ejemplo, preconizó la creación de organismos que evocan a las actuales "denominaciones de origen" para impulsar la vinicultura: "hay que crear agrupaciones de vinos con caracteres fijos y nombre conocido, por medio de una propaganda activa e incesante» [35-36].

Insertar a la economía española en una división internacional del trabajo, determinada por una especialización eficiente, hecha posible en el marco de una libertad de comercio generalizada: ese era el objetivo de las reformas 
arancelarias propugnadas por Costa. Un objetivo que claramente corresponde a un liberal y está en las antípodas de ese pretendido oligarquista o prefascista que anunciaron con oportunismo y desconocimiento ciertos ensayistas. La economía también ayuda a caracterizar actitudes políticas y por eso es útil examinar a Costa desde ese punto de vista.

El segundo tema abordado por Joaquín Costa con carácter preferente en sus discursos librecambistas es el de los mercados exteriores. Tenía enjundia en el pensamiento costista y, a la vez, era oportuno y relevante en la España de los primeros ochenta. De esto último ya se ha hablado al explicar los debates sobre los tratados de comercio. En relación con su pensamiento, la idea de fomentar el comercio exterior como signo de prestigio enlazaba con una honda preocupación por la geoestrategia, que durante aquellos años le fascinó y le hizo dedicar, poco después, tiempo y esfuerzo a la Sociedad de Geografía Comercial y su revista. Esa preocupación, en términos generales, se refería a su visión del comercio como medio para la expansión internacional de España o, en sus propias palabras, "el ideal exterior de nuestra patria, en sus relaciones con el problema arancelario" [63]. En un sentido más concreto, se ligaba con su interés por el iberismo, el americanismo y el africanismo. ${ }^{73}$

En todo esto el comercio servía a la vez intereses económicos y políticos, algo que ahora puede parecer extraño, pero no así en la época. Sobre el papel, el liberalismo de mediados del xix había entronizado al ideal cosmopolita, al tiempo que ensalzaba al comercio como un medio de fomentar la paz y la fraternidad entre los pueblos. Sin embargo, el país que encarnaba el liberalismo político y

73 Sobre el africanismo en Costa y su activismo en los años ochenta resulta imprescindible E. Fernández Clemente (1977). Sobre la Sociedad de Geografía Comercial, véase J. Velarde Fuertes (2007). 
el librecambio, Gran Bretaña, no dejaba de sumar colonias y nadie parecía reparar en que hubiese contradicción alguna entre ambos principios. De manera que liberalismo y colonialismo resultaban por entonces perfectamente congruentes. De hecho, en el último tercio de la centuria los demás países europeos importantes se lanzaron igualmente a la expansión exterior. En este contexto de colonialismo, Costa aspiraba a que España imitase a los grandes países europeos y alcanzase a ocupar un lugar entre ellos.

Pues bien, en dicha aspiración, a Costa le preocupaba que el volumen del comercio exterior de España fuese muy reducido en términos relativos (comercio por habitante, puesto que en aquel tiempo no había cifras de renta), porque interpretaba que era un indicador de falta de capacidad económica para acceder a la condición de potencia. De manera que sostenía "la urgente, la apremiante necesidad de acrecentar nuestro comercio exterior, y no así como se quiera, poco a poco y en proporción aritmética, sino rápidamente y por masas, si no hemos de quedarnos tan atrás de los demás países que nos sea ya después de todo punto imposible el alcanzarlos. Esto supuesto, no es menester que yo os diga que el comercio exterior principia por la exportación, porque sin ella no hay importación; y hemos de acrecentar la exportación, y, por consiguiente, la producción de objetos exportables, abriendo mercados que hoy tenemos cerrados, o poco menos, ofreciendo ventajas a cambio de ventajas, con reciprocidad arancelaria" [7]. Esto le llevaba, a su vez, a defender la agricultura de exportación, en particular, por entonces, la viticultura y los tratados de comercio. Su interés por la cuestión era tan grande que aún años después publicaría periódicamente en la Revista de Geografía Comercial notas sobre los procesos de negociación comercial (aunque no están firmadas, hemos recogido en un apéndice las a él atribuidas). 
En cuanto a los planes concretos, su discurso de enero de 1882 es un vibrante programa de acción exterior respecto a Portugal y América. Sobre América, comienza por una declaración: "Nosotros, los españoles, seremos siempre tanto como un pueblo europeo, acaso más que un pueblo europeo, un pueblo americano" [51]. Continúa con la formulación de un objetivo: "Vamos a reconquistar la América; pero a condición de que a esa reconquista destinemos ejércitos de mercaderes y de cónsules, de libreros y de profesores. Para romper el hielo que todavía mantiene divorciadas la España peninsular y la España ultramarina, debemos apelar en primer término a ese poderoso fundente que se llama el comercio" [55]. Y concluye con una petición para alcanzar ese objetivo, la de «declarar interior todo nuestro comercio con las naciones hispanoamericanas: con esto solo se habría suprimido más de la mitad de la distancia moral que nos separa de ellas" [55].

Respecto a Portugal es aún más taxativo: «Si, como antes os he dicho, deseo la unión aduanera con la América española, si yo aspiro a que se declare comercio interior todo el que aquellas repúblicas hacen con nosotros, qué os diré de Portugal, no ya nación filial como ellas, sino pedazo de la metrópoli. [...] No son, no, los portugueses extranjeros para nosotros: Portugal es nuestra patria con igual derecho que Aragón, que Cataluña o que Andalucía" [58-59]. Y por ello mismo es su plan más ambicioso, hasta el punto de reclamar una unión económica completa que concluya en unión política o, mejor dicho, en reconstitución de la que, para Costa, nunca se debió perder. He ahí el iberismo en su apogeo, "La unidad económica lleva en germen y trae fatalmente en pos de sí la unidad política. Dadme una liga aduanera, y antes de medio siglo os devolveré una confederación política: cuarenta años han bastado para pasar de Federico List hasta Bismarck, para convertir el Zollverein en un imperio germánico. Hagámonos la cuenta de que la unión ibérica es como un haz de 
uniones parciales, la unión aduanera, la unión marítima y consular, la unión postal y monetaria, la unión literaria y profesional, la unión colonial, la alianza defensiva, la alianza ofensiva, etc.; procurémoslas una tras otra, y así, lentamente, por asimilaciones parciales, y contando con la virtud creadora del tiempo, volveremos a la vida esa España de nuestros ensueños que por la fuerza no lograríamos jamás" [63].

En su discurso de enero no había podido referirse a África por falta de tiempo ("Siento no poder examinar esta tarde, con el mismo sentido, el problema de África y el de Gibraltar. Lo avanzado de la hora me obliga a concluir en este punto" [63]). Pero lo hizo en su siguiente discurso en la Asociación para la Reforma de los Aranceles de Aduanas, en mayo del mismo 1882. "La vida nacional no se halla reducida a los estrechos límites de la Península: tenemos que exteriorizarnos por África, por América, por Oceanía, y, para exteriorizarnos, no nos son menos necesarios los tejedores que los soldados, no nos es menos indispensable la marina mercante que la marina de guerra. Por la extensión de nuestras costas y de nuestras colonias, somos la cuarta potencia marítima, y necesitamos ser, por tanto, cuando menos, la cuarta potencia mercantil y la cuarta potencia naval: desgraciadamente, en uno y en otro respecto, somos la octava o la novena, y tenemos que apresurarnos mucho si hemos de equilibrarnos con los demás países y tomar parte activa en el concierto de la civilización" [89]. Aquí encontraba Costa, por fin, un papel para la industria en el conjunto de la actividad económica nacional. Con sus palabras: "Si el vino constituye hoy nuestro principal artículo de exportación y el lazo social que nos liga con Europa, que es el presente, el hilo y la tela de algodón deben ser el vínculo que nos enlace con África, donde está una gran parte de nuestro porvenir. En Marruecos, en el golfo de Guinea, en las posesiones africano-portuguesas de Angola y Mozambique, habitan infinidad de 
razas que necesitan de nosotros para salir del estado de abyección en que se encuentran, y a las cuales necesitamos nosotros para asegurar a nuestra raza un porvenir colonial digno de nuestro pasado" [90].

Finalmente, el tercero de los grandes temas abordados por Costa en sus discursos librecambistas gira en torno a la estrategia de reforma de la política comercial adecuada para alcanzar el ideal librecambista. En términos generales, se muestra confiado en que los tiempos del proteccionismo han pasado y sus defensores solo alcanzarán a retrasar el inevitable triunfo de la libertad; "el proteccionismo, que un día lo fue todo, está agotándose en las últimas convulsiones de la agonía y preparándose a confundirse con la nada" [22], decía en 1881. Esta confianza le venía de considerar a los proteccionistas una exigua minoría, que "alcanza a un corto número de fabricantes de tejidos, de harinas y de azúcar, y a unos cuantos navieros; sin contar, por supuesto, los contrabandistas" [22]. Eran años de un optimismo desbordante que, sin embargo, en menos de un decenio se revelaría completamente infundado. A comienzos de los noventa el proteccionismo había triunfado en toda la línea y quienes desaparecieron fueron los librecambistas. Pero esta es otra historia.

La que aquí interesa es la de que Costa y los miembros de la Asociación habían identificado perfectamente los intereses enfrentados y se quejaron a menudo de los políticos titubeantes, aunque no interpretaran bien la fuerza de esos intereses ni el oportunismo de los políticos. Así, Costa en 1882 denunciaba el quietismo y las componendas del Gobierno fusionista: «iLa reforma arancelaria! ¡Quién hubiese dicho hace pocos años al Sr. Camacho y al Sr. Albareda y al Sr. Sagasta que, doce meses después de ocupar el poder, seguiría rigiendo todavía aquel inicuo decreto de 17 de julio de 1875, por el cual una dictadura enemiga del país entregó el país atado de pies y manos a 
merced de unos cuantos industriales divorciados de su patria! ¡Quién hubiese dicho a aquellos denodados campeones del librecambio que harían mella en su espíritu las preocupaciones internacionales de los proteccionistas de buena fe, y que buscando transacciones y componendas entre su conciencia y el error, entre sus convicciones y sus miedos, habrían de proyectar una reforma mestiza, informada en el absurdo principio de la reciprocidad [...] que representa un triunfo para el proteccionismo" [43].

Aparece aquí una de las disyuntivas que más contradicciones generaron en los librecambistas durante aquellos años: aceptar los tratados de comercio como un medio para alcanzar el librecambio, o bien exigir el desarme unilateral como vía más ortodoxa. En este punto Costa es fiel reflejo de esas contradicciones, pues aquí abomina del principio de reciprocidad, inspirador y fundamento de los tratados de comercio, cuando hay otros múltiples testimonios a favor de la firma de acuerdos comerciales para abrir mercados a la exportación española. Era la duda entre seguir la estrategia posibilista de apertura mediante convenios, como se había hecho tras el mítico tratado francobritánico de 1860 firmado por Richard Cobden y Michel Chevalier, o la vía más difícil de los desarmes unilaterales adoptada por Figuerola en 1869. Los librecambistas españoles aceptaron finalmente en los ochenta la vía de los tratados con pocas voces discrepantes y hasta celebraron meetings para defenderlos, pensando en sumar adeptos entre los agricultores interesados en la exportación, principalmente viticultores. Sin embargo, su aceptación de los convenios los introducía en la lógica de la reciprocidad y los dejaba inermes si los otros países no aceptaban negociar, como ocurrió con Francia en 1892. En este caso, la dinámica de la negociación, con el argumento de agrandar el atractivo, terminó en una elevación de derechos, ya en los noventa, con el fin declarado de poder ofrecer concesiones más sustanciosas. 
Si en el tema de los tratados Costa se mostraba radical en los principios, aunque flexible en la política, en la otra controversia estratégica que había dividido a los librecambistas tras el 69 -desarme inmediato o pausado- se alineó con el grupo más intransigente. Así, en 1881 defendió la enmienda realizada en su día por Gabriel Rodríguez contra el Arancel Figuerola: "con previsión exquisita, que los sucesos convirtieron en vaticinio, escribía en su voto particular el actual Presidente de esta Asociación que "no se podía explicar el empeño con que algunos defendían la subsistencia del antiguo Arancel durante seis años sino por la esperanza de dificultar y paralizar la reforma dentro de ese plazo" y pedía, en consecuencia, que la rebaja gradual empezara desde el primer año. La enmienda fue desechada: los seis años estaban a punto de trascurrir; faltaban días solo para que se decretara esa primera rebaja, cuando el proteccionismo, haciendo alarde de una ingratitud y de una deslealtad tan grandes como grande había sido la honrada candidez de los liberales, mintió a la santa religión de la palabra y no se avergonzó de recabar el decreto de 17 de junio de 1875, por el cual se suspendía la ejecución de la reforma de 1869, aprovechando uno de los momentos más angustiosos y terribles por que ha pasado nuestra patria: el momento en que estaba derramando torrentes de sangre y consumiendo su fortuna en las montañas de Cataluña y de Navarra por sacar incólumes su honra, su nombre, su porvenir y su dignidad" [29].

En cualquier caso, los discursos librecambistas de Joaquín Costa ilustran sobre sus ideas económicas y las controversias arancelarias del XIX español, ya se ha dicho, además de permitir conocer más a fondo al personaje y encontrar en él la formulación temprana de algunas de las ideas que ahora parecen propias del Costa maduro. Con otras palabras, en los discursos librecambistas es posible encontrar a Costa en Costa sin que sea preciso esperar al ambiente del Desastre y el regeneracionismo tardío. 
Así, ya están en ellos presentes sus críticas a la inacción de los políticos y al exceso de retórica vacía en la vida pública española. Decía en 1881: "Ha entrado España en una era eminentemente positiva, que no se paga de palabras: está ya harta de discursos y hambrienta de obras, y principia a cansarse de esa brillante plana mayor de oradores y de retóricos que sienten y dicen tan bien lo que después han de practicar tan mal. A la generalidad del país no le importa que esté en el poder Fulano o Zutano; lo que le importa es que gobierne, y gobernar no es pasar por el banco azul, hablar, cobrar y dimitir: es obrar, y la historia, a los Gobiernos que pasaron no los conoce por sus programas ni por sus manifiestos, sino por sus obras. Un Gobierno mudo, pero activo y reformador, un Gobierno sin lengua, pero con brazos: este es hoy por hoy el ideal político de nuestro pueblo. (Aplausos). ¿Os parece que vale la pena agitar al país con elecciones, reunir en dos Asambleas la flor de la nación, sostener empeñadas batallas con los adversarios, consumiendo tesoros de ingenio en cien debates, para que en fin de cuentas Cánovas o Sagasta o Castelar o Ruiz Zorrilla sean Poder toda su vida, y se despidan luego del mundo sin dejar nada tras de sí, y diciendo como el Rey Sol: "Ha terminado la comedia"?" [37]. Sobre lo que un año más tarde insistía: "En España, por el contrario, los estadistas [...] pasan la primera mitad de su vida haciendo propósitos de reformas y fabricando un programa para batir con él el alcázar del poder, y la otra mitad arrepintiéndose de él y dando la razón a sus adversarios, quemando los ídolos que antes habían adorado, y contribuyendo a que la política española sea una verdadera tela de Penélope, y a que el pueblo español viva en una eterna infancia, sin ley, sin gobierno, sin ideales, hambriento de pan y de cultura, y orillado a un lado en la corriente del progreso como una escoria de la civilización" [72]. 
Terminamos diciendo que no eran solo los políticos el objeto de su crítica, como más tarde le reprochó Ortega. ${ }^{74}$ En los discursos extendía los reproches a sus conciudadanos: "yo tengo la idea de que los españoles hablamos muchos y estudiamos poco, y que una de las cosas que más y con más urgencia necesitamos es aprender a callar", diría en 1883 [97]. Quizá Costa no insistió mucho en ello porque le parecían más graves los errores de los políticos, pero no por falta de consciencia de las debilidades de los gobernados.

\section{NUESTRA EDICIÓN}

Los textos que se reproducen a continuación corresponden a los cinco discursos pronunciados por Joaquín Costa a comienzos de los años ochenta del XIX con un inequívoco sentido librecambista. No se trata de textos en los que Costa se refiera en mayor o menor medida a cuestiones comerciales o defienda incidentalmente la libertad de comercio, sino que son monografías específicas y compactas. Tienen además la particularidad de ser todas ellas piezas oratorias. Cronológicamente, el primer discurso lo pronunció el 18 de mayo de 1881 en el 2. ${ }^{\circ}$ Congreso de Agricultores y Ganaderos y los cuatro restantes en otros tantos meetings de la Asociación para la Reforma de los Aranceles de Aduanas, el 28 de junio de 1881, el 8 de enero de 1882, el 21 de mayo de 1882 y el 24 de junio de 1883. Es decir, que los cinco discursos abarcan un período de apenas dos años.

74 "Por eso no pienso como Costa, que atribuía la mengua de España a los pecados de las clases gobernantes, por tanto a errores puramente políticos. No; las clases gobernantes durante siglos — salvo breves épocas- han gobernado mal no por casualidad, sino porque la España gobernada estaba tan enferma como ellos". J. Ortega y Gasset (2006), tomo I, p. 715 . 
George J. G. Cheyne, en su magnífico Estudio bibliográfico, al cual los estudiosos de Costa deben rendir permanente tributo de reconocimiento, alude a varios discursos librecambistas. En el punto 531 menciona el discurso del 8 de enero de 1882, incluido en Estudios jurídicos y políticos, y añade que "según una nota en AHN (112), Costa dio varios discursos sobre este tema en cinco reuniones distintas. De momento solo he encontrado este». ${ }^{75}$ En realidad, eran cuatro en los meetings de la Asociación para la Reforma de los Aranceles de Aduanas, como se ha señalado, y se puede considerar - como se ha hecho en esta edición- que hay un quinto discurso, el correspondiente al Congreso de Agricultores y Ganaderos de 1881. Posteriormente se refirieron a los discursos de la Asociación, Cristóbal Gómez Benito y Alfonso Ortí ${ }^{76}$ quienes dieron noticia de los ejemplares conservados en el Archivo Histórico Provincial de Huesca.

En conjunto, estos textos han compartido lo que se ha llamado con acierto el "infortunio" de la obra costiana. ${ }^{77} \mathrm{El}$ primer discurso está catalogado con el número 528 en el Estudio bibliográfico de Cheyne. ${ }^{78}$ Fue incluido por su her-

75 G. J. G. Cheyne (1981), p. 167.

76 C. Gómez Benito y A. Ortí (1996). Ver números 72, 73 y 74.

77 Alfonso Ortí habló del "infortunio" aludiendo a los disparates que Tomás Costa realizó con la obra de su hermano. A. Ortí (1996), p. 519. Se puede generalizar la expresión para incluir los muchos textos que permanecen inéditos o en ediciones muy difíciles de localizar hoy. Se trata de uno de los principales problemas para hacer una valoración cabal de la figura de Costa.

78 "La agricultura española y la libertad de comercio (18.5.1881). Discurso dado en el Congreso de Agricultores y Ganaderos, Madrid. Reimpreso con el mismo título, en Boletín de la Institución Libre de Enseñanza: V. 108 (16.8.1881), 116-118; 109 (31.8.1881), 122-125. Y en la Cámara del Alto Aragón, II, 56 (23.4.1897); 57 (30.4.1897); 58 (7.5.1897). Forma parte del texto de cap. vi de ambas ediciones de Agricultura armónica (La Fórmula..., t. I, 133-144; Bib. Econ., 151-164) desde el párrafo 11 hasta el final del capítulo. Véase n. ${ }^{\circ}$ 725. Reproducido por A. Orti en Agricultura y Sociedad, I (octubre-diciembre 1976), 327-336". G. J. G. Cheyne (1981), p. 167. 
mano Tomás en Agricultura armónica, en las páginas 151 a 164 del tomo i de la Biblioteca Económica (Biblioteca J. Costa, Madrid, 1911). Figura como epígrafe il del capítulo vi ("El cultivo cereal es antieconómico en España"), con el título "La agricultura española y la libertad de comercio" y la siguiente nota: "Un año después del anterior discurso [se refiere al pronunciado por Costa el 25 de mayo de 1880 en el primer Congreso de Agricultores y Ganaderos que aparecía en las páginas anteriores] pronunciaba este, hermosísimo, lleno de vigor, de doctrina y de patriotismo, en el Congreso de Agricultores y Ganaderos celebrado el día 18 de mayo de 1881. La publicación de este trabajo es de gran actualidad. $N$. del $H$. .. De ahí lo hemos tomado.

Los cuatro discursos pronunciados en los meetings de la Asociación para la Reforma de los Aranceles de Aduanas fueron publicados originalmente en otros tantos folletos de la Asociación que recogían todas las intervenciones del acto, y no solo la de Costa, como es lógico. Los folletos son poco conocidos y nunca llegaron a reeditarse. ${ }^{79}$ Uno de los discursos de Costa fue, sin embargo, incluido por él mismo en su libro Estudios jurídicos y políticos de 1884; se trata del pronunciado el 8 de enero de 1882, que aparece como artículo iII con el título "Los aranceles de

79 Asociación para la Reforma de los Aranceles de Aduanas, Meeting Libre-cambista sobre la Urgencia de la Reforma Arancelaria (celebrado en el Teatro de la Zarzuela el día 26 de junio de 1881), Madrid, Imprenta de E. de la Riva, 1881. Asociación para la Reforma Liberal de los Aranceles de Aduanas, Meeting celebrado en el Teatro de Apolo el día 8 de enero de 1882, Madrid, Imprenta de E. de la Riva, 1882. Asociación para la Reforma Liberal de los Aranceles de Aduanas, Meeting celebrado en el Teatro de la Comedia el día 21 de mayo de 1882. Tema: Urgencia del levantamiento de la suspensión de la Base Quinta de la Ley Arancelaria: necesidad de decretar la libre importación de cereales, Madrid, Imprenta de E. de la Riva, 1882. Asociación para la Reforma Liberal de los Aranceles de Aduanas, Meeting Libre-cambista celebrado en el Teatro de la Comedia el día 24 de junio de 1883. Tema: Estado actual de la cuestión arancelaria, Madrid, Imprenta de E. de la Riva, 1883. 
aduanas y la política con Portugal y América", dentro del capítulo IV, "Política exterior y colonial de España". Una nota tras el título del artículo III aclara que se trata del "Discurso en el meeting celebrado por la Asociación para la Reforma Liberal de los Aranceles de Aduanas el 8 de enero de 1882". Cheyne catalogó el libro con el número 30 en su Estudio bibliográfico. ${ }^{80}$ El texto lo hemos tomado de Estudios jurídicos y políticos, al tratarse de una versión revisada por el propio Costa, que incluyó una nota de actualización y realizó algunos cambios menores. No obstante, hemos señalado los cambios como Notas del Editor ( $N$. del E.). También estableció al comienzo un índice temático, que hemos conservado.

Los tres discursos restantes solo fueron publicados en los folletos de la Asociación para la Reforma de los Aranceles de Aduanas, ${ }^{81}$ pero Costa debió tener intención de reeditarlos en algún momento, pues en el Fondo Costa del Archivo Histórico Provincial de Huesca se encuentran ejemplares con algunas correcciones a mano del propio autor. No son grandes cambios, más bien matices y alguna errata subsanada. En este caso hemos tomado también la versión revisada por Costa, aunque de nuevo señalando las modificaciones con Notas del Editor. Del discurso de 21 de mayo de 1882 hay dos ejemplares, uno con el folleto de la Asociación para la Reforma de los Aranceles de Aduanas completo (carpeta 113.18) y otro con la intervención de Costa y algunas páginas más (carpeta 105.14). De los discursos de 26 de junio de 1881 y 24 de junio de 1883

80 "Artículo III. "Los aranceles de aduanas y la política con Portugal y América" es el texto de un discurso dado en el meeting de la Asociación para la reforma liberal de los Aranceles de Aduanas (Madrid, 8.1.1882), y mencionado brevemente en El Liberal (9.1.1882) con el título de "El Meeting de ayer". Sin duda otros periódicos publicaron también resúmenes». G. J. G. Cheyne (1981), p. 71.

81 Existe una edición no venal en facsímile realizada por Fundear y el Colegio de Economistas de Aragón en 2011. 
solo se encuentran las páginas de los discursos de Costa con las correcciones mencionadas, aunque sin indicación de fecha, ni detalle de la edición o el meeting al que pertenecían (carpeta 105.14).

Otros textos de Joaquín Costa aluden a cuestiones comerciales o defienden el librecambio, según se ha dicho, pero lo hacen tangencialmente y sin el carácter específico de los discursos. Así, diversos trabajos aparecidos en Revista de Geografía Comercial incluyen alguna consideración sobre tratados de comercio o comercio y colonias, pero en modo alguno tienen una entidad comparable a los cinco mencionados, pues se trata de informaciones prácticas o glosas breves de artículos periodísticos. No obstante, hemos incorporado como apéndice aquellos artículos de Revista de Geografía Comercial que se refieren de forma más directa a la política comercial ("Tratados de comercio I y II", "Cuándo debemos adquirir colonias", "La exportación de manufacturas catalanas y el precio del trigo en España"). ${ }^{82}$ También hemos incluido el índice completo de los trabajos de Costa en dicha revista, tal como fue publicado en 1896 en el número 158 de la misma. Todo ello, con objeto de que el lector de hoy tenga testimonio del continuado interés de Costa a mediados de los ochenta por las cuestiones comerciales y de la conexión entre sus posiciones librecambistas y la preocupación por la geografía.

82 Corresponden en el Estudio bibliográfico de Cheyne a los números 410 ("Tratados de comercio I y II"), 412 ("Cómo debemos adquirir colonias") y 420 ("La exportación de manufacturas catalanas y el precio del trigo en España"). G. J. G. Cheyne (1981), p. 157. 


\title{
DISCURSOS LIBRECAMBISTAS
}

\author{
Joaquín Costa
}



"LA AGRICULTURA ESPAÑOLA Y LA LIBERTAD DE COMERCIO"

Discurso pronunciado en Madrid en el Congreso de Agricultores y Ganaderos el día 18 de mayo de 1881 



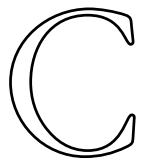

UANDO YO OÍA DECIR al Sr. Castañeda que la agricultura española paga a los fabricantes de tejidos finos de lana un impuesto indirecto de $600 \mathrm{a}$ 700 millones de reales en forma de sobreprecio, por efecto de la carestía artificial que trae consigo la protección arancelaria; cuando oía al Sr. Casabona dirigir graves cargos, en nombre de la agricultura, a los librecambistas de esta banda, como pudiera dirigirlos a una nuera para que lo entendiese la suegra, que es aquí la industria proteccionista catalana, me decía yo, a mí mismo por lo bajo: "es triste sino el sino de la agricultura española; desde los primeros siglos de la Edad Media hasta la centuria presente, ha sido víctima de la ganadería: por favorecer a los ganados mesteños, el legislador oprimía cruelmente a los labradores. La emancipación estaba a punto de ser un hecho, cuando he aquí que surge de pronto enfrente de ella un nuevo enemigo, la industria de tejidos, que, como cosa de lana, naturalmente ha heredado las tradiciones de privilegio y los instintos belicosos de los antiguos ganaderos; y la agricultura, obligada a combatir esta nueva Mesta industrial, no menos temible, porque no es menos desleal, ni menos egoísta, ni más escrupulosa que la antigua, descuelga las armas con que triunfó del Honrado Concejo, armas, aunque antiguas, no viejas ni mohosas, sino dotadas de una juventud eterna, porque esas armas son la igualdad y la justicia enfrente del egoísmo, de la expoliación y del privilegio". 
Se está discutiendo la influencia que el comercio exterior ejerce y puede ejercer en el desarrollo de nuestra agricultura, y voy al tema sin preámbulos.

Vosotros sabéis que nuestro comercio exterior es mezquino, que no excede de cuatro mil millones de reales al año, sumadas la importación y la exportación; o en términos más claros y tangibles: que nuestro comercio con el extranjero se reduce a unos 12 duros por cada español, cuando llega a 30 por individuo en Francia, a 100 en Inglaterra y a 180 o 190 en Bélgica; Bélgica, señores, que cuenta solo cinco millones de habitantes y hace cinco veces más comercio exterior que nosotros. Esto significa que producimos poco, y, como esto poco que producimos no nos excusa de gastar mucho, resulta la vida del español una de las más difíciles y premiosas de Europa. Fuera de Austria, somos el pueblo más recargado de tributos, al extremo de que los labradores abandonan sus fincas por centenares de miles al Tesoro público en equivalencia de la contribución de solo un año; como decían hace una semana las ligas de contribuyentes al Presidente del Consejo de Ministros: "son tan enormes los tributos, que hacen más que agobiar, aniquilan las fuentes de la riqueza pública", añadiendo que es absolutamente preciso reducir el tipo de los impuestos vigentes. Con efecto, en cuarenta años ha crecido nuestro presupuesto de gastos desde 300 millones de pesetas a 800: desde el año de 1868 - y ya veis que la fecha no es remota- ha aumentado la contribución territorial en un 50 por 100, y en más de un 70 la industria: igual casi nuestro presupuesto de gastos a la cifra del comercio exterior, cuando en Francia no excede del 40 por 100, en Inglaterra del 15, y en Bélgica del 10. Y es lo más doloroso del caso que todavía eso no basta; que de tan enormes sacrificios no alcanza al Ministerio de Fomento sino el 8 por 100, con tendencia a bajar de año en año; que los contribuyentes aseguran en la instancia que antes he citado que no es posible continuar tributando lo que se tributa, y lo repetía en este sitio antea- 
yer, con aplauso general porque está en la conciencia de todos, el distinguido economista Sr. Bona; y sin embargo de estar pagando más de lo posible y viviendo sobre el capital, todavía no tenemos para canales, ni para escuelas, ni para buques de guerra. Cuán vital sea este problema, no he de ponderároslo yo: es tan contado el número de minutos disponibles que no he de intentar ponerlo de relieve: me limitaré a citar un hecho que vale por un libro. Hace pocos meses, un periódico inglés que, a pesar de ser conservador, es uno de los periódicos más sesudos del Reino Unido - me refiero a The Saturday Review - se burlaba muy discretamente de nuestras pretensiones a ser reconocidos como potencia de primer orden, fundándonos en que lo es Italia, y entre las varias razones, casi todas de peso, en que apoyaba su sátira verdaderamente sanchesca, que me hizo tragar mucha saliva, pero que me hizo pensar, ponía en primer término la exigüidad de nuestro comercio exterior.

No hace falta decir más para que se comprenda la urgente, la apremiante necesidad de acrecentar nuestro comercio exterior, y no así como se quiera, poco a poco y en proporción aritmética, sino rápidamente y por masas, si no hemos de quedarnos tan atrás de los demás países que nos sea ya después de todo punto imposible el alcanzarlos. Esto supuesto, no es menester que yo os diga que el comercio exterior principia por la exportación, porque sin ella no hay importación; y hemos de acrecentar la exportación, y, por consiguiente, la producción de objetos exportables, abriendo mercados que hoy tenemos cerrados, o poco menos, ofreciendo ventajas a cambio de ventajas, con reciprocidad arancelaria. ¿Y qué es de lo que las extranjeras necesitan y solicitan de nosotros, lo que nosotros podemos producir en grandes cantidades y en poco tiempo? ¿Quién tiene la posibilidad y sobre quién pesa, por tanto, la responsabilidad y el compromiso de acrecentar rápidamente el comercio de exportación y de sentar solidariamente las bases de nuestra regeneración y de nuestro porvenir? ¿Será 
la industria fabril y manufacturera? Ya lo habéis contestado vosotros, no: es la agricultura; a ella se debe que nuestro comercio exterior haya crecido, en solo diez años, desde 3000 a 4000 millones, a pesar de haberse suspendido los efectos de la reforma arancelaria de 1869, y de no haberse celebrado tratados de comercio: a ella hemos de deber que en otros diez años ascienda desde 4000 a 10000, y después en una progresión mayor: a ella, que no a protecciones fundadas en privilegios odiosos, ha de deber también la industria nacional su prosperidad y florecimiento, porque, si es verdad que todo producto se compra con producto, si el comercio se reduce en último análisis a una simple permuta de géneros - no siendo el dinero sino un medio de hacer más fáciles y rápidos esos cambios de productos-, constituyendo como constituimos mayoría en España los labradores y minoría los industriales, es claro como la luz del día que el modo más eficaz de fomentar la industria es hacer que los labradores tengan muchos productos agrícolas que ofrecer a cambio de productos industriales; no siendo la verdadera, la recíproca, porque, sobre ser minoría los industriales, todavía lo que producen lo producen a expensas de la protección forzosa que les dispensan los más, o sea los labradores; ni tampoco la protección de unos y de otros porque en el fondo viene a traducirse en una expoliación mutua, antes rémora que incentivo y estímulo para el trabajador.

Esto supuesto, ¿qué es lo primero que hay que hacer para aumentar nuestro comercio exterior y, por tanto, la producción nacional? Pues lo primero que hay que hacer, con toda evidencia, es abrir mercados amplios fuera de las fronteras a los productos de nuestra agricultura, señaladamente al vino, que representa ya el 40 por 100 de nuestro comercio de exportación, y más en concreto aún, al vino común o de pasto, cuyo comercio solo en el transcurso de un año ha doblado casi su exportación, desde 110 a 200 millones de pesetas, es decir, casi toda la diferencia en más 
que registra la estadística de exportación total entre 1879 y 1880. Urge, pues, abrir el mercado de los Estados Unidos a nuestros vinos jerezanos y generosos a cambio de los cuales podrán surtir de trigo barato a nuestras provincias del Norte, abrir salida fácil a nuestros azúcares antillanos y asegurarles el porvenir, hoy tan gravemente comprometido, y prestar animación a la decaída industria naviera. Urge asimismo consolidar el convenio celebrado con Francia en 1865 y modificado en 1877, que tan a tiempo vino a reanimar nuestra abatida agricultura, y urge tanto más cuanto que, mientras no cambien nuestras relaciones mercantiles con Inglaterra, Francia es el mercado forzoso del artículo que representa nuestra primera fuente de riqueza; y urge tanto más cuanto que, en virtud de la nueva ley arancelaria francesa, dicho tratado ha quedado denunciado, que no carece de enemigos poderosos en el seno del Parlamento francés, que Italia y Portugal se agitan con febril actividad en la capital de la vecina República, a fin de preparar la renovación de los tratados denunciados, y que, si Italia obtuviese de Francia y Francia de Inglaterra condiciones más ventajosas que España para el comercio de vinos, la agricultura española volvería fatalmente a caer en aquel estado de postración en que estaba antes de 1878, y de que ha principado a sacarla el comercio exterior de caldos. No urge menos abrir de par en par las puertas del mercado inglés, negociando la reducción o la supresión de la escala alcohólica, a fin de que nuestros vinos comunes, superiores como vinos baratos, como vinos de pueblo, a los franceses, y en busca de los cuales han empezado ya a venir a España comisionados de Inglaterra, puedan expender al mismo precio que los de Francia, y dejemos de depender, como casi exclusivamente dependemos, del mercado intermediario francés, de suyo poco seguro, porque tiene una base inestable y transitoria, la filoxera, que no ha de ser una plaga eterna. Con esto aumentará rápidamente el consumo y, por tanto, el pedido, y se precipitará la transformación de 
las tierras cereales en viñedos, hasta tanto que exportemos más vino del que hoy producimos.

No falta quien opina - el Instituto Agrícola Catalán de San Isidro, por ejemplo, en su petición de marzo últimoque no es la escala alcohólica la causa de que nuestros vinos comunes no tengan salida en Inglaterra, sino el no tener costumbre de beberlo el pueblo inglés, y el carecer nuestros cosecheros de arte y habilidad para adaptarlos a su gusto. Tanto valdría decir que nuestros jornaleros no visten de seda ni habitan palacios porque no se ha infiltrado en sus costumbres la necesidad de los palacios y de las sedas. Pues los tripulantes de los buques ingleses, ingleses son, y deben estar adoptados a sus gustos nuestros vinos, a juzgar por los primeros establecimientos que visitan cuando desembarcan en un puerto de la Península. Ni debe ser tan inútil y tan ineficaz la reducción de la escala alcohólica inglesa, cuando tanto preocupa a las revistas francesas de vinicultura, por ejemplo, al Moniteur Vinicole, la eventualidad de un tratado de comercio entre España y el Reino Unido, que tienen por seguro que habría de quebrantar la industria vinatera francesa. No entraré a discutir las razones que aduce el Instituto en su representación del mes de marzo, porque no es esta mi misión: allá se las entienda el Instituto barcelonés con la Asociación de Agricultores de Manresa, con los librecambistas de El Ampurdanés y con muchísimos agricultores de Lérida y Tarragona, cuyas peticiones obran en poder de la Asociación para reforma liberal de los aranceles de aduanas, y fuera de Cataluña, con esta misma Asociación que acabo de nombrar, con la de ingenieros agrónomos, con los diputados andaluces, con el Círculo de la Unión Mercantil, con el señor marqués de Monistrol y la mayoría de la grandeza madrileña, y con los miles de cosecheros que suscriben 200 peticiones procedentes de todas las regiones de España; todos los cuales opinan de modo distinto a como opina el citado Instituto Agrícola. 
Como es natural, para que las demás naciones se presten a abrir sus mercados a nuestros productos agrícolas, reclamarán en justa reciprocidad que abramos a sus productos industriales y agrícolas nuestras fronteras. Y en esto los cosecheros de granos y los fabricantes de tejidos creen ver su ruina. Tenemos, pues, frente a frente, ostentando intereses opuestos, del lado de la libertad de comercio, los vinos y la ganadería; del lado de la protección arancelaria, los cereales y los tejidos de lana. Este es el problema que se está ventilando, y ya me tenéis en materia. Voy a examinar el problema desde el punto de vista de los cereales, y después desde el punto de vista de los tejidos.

$\mathrm{Y}$ ante todo la resistencia que los cereales castellanos (no quiero llamarlos españoles) oponen a la reforma de los aranceles ¿es racional o es infundada? Y segundo: ¿es real o, más que real, es aparente?

Ya recordaréis, señores, que en el Congreso del año pasado hemos convenido, por una especie de tácito acuerdo, en que el cultivo de cereales, en las condiciones en que actualmente se practica, es ruinoso para España, y que hay que sustituirlo por el cultivo arbustivo y la cría de ganados. El Sr. Casabona nos decía hace un instante que posee datos para demostrar que son frecuentes los casos en que ni siquiera hay equilibrio entre los gastos y la producción, en que el cultivo cereal se salda con pérdidas. De suerte que proteger el trigo sería fomentar un cultivo que está condenado necesariamente a desaparecer, a expensas de otros dos o tres que están llamados a enseñorearse de nuestra agricultura; sería fomentar lo que representa la ruina y la miseria de España, a expensas de lo que representa su riqueza y su porvenir. Como hay que condensar mucho el pensamiento y expresarlo por medias palabras, aquí tenéis mi fórmula respecto a cereales. Nuestro presente agrícola se traduce en esto: un millón y medio de hectáreas plantadas de viña, que producen 36 millones de hectolitros de vino, de los cuales exportamos 6; y 15 millones de hec- 
táreas sembradas de cereales, que arrojan un producto anual de 100 a 120 millones de hectolitros de grano: el ideal a que debemos encaminar todos nuestros esfuerzos se resume en las siguientes cifras: 4 o 5 millones de bectáreas, en vez de 15, sembradas de cereales, que rindan, sin embargo, los mismos 100 bectolitros de grano o poco menos, y 4 millones de hectáreas, en vez de uno y medio, plantadas de viña, que produzcan 90 millones de bectolitros de vino, de los cuales exportemos 50 con un valor de 5 a 6000 millones de reales: yo no me atrevo a aceptar las cifras propuestas por el Sr. Alvarado, porque es poco sólida y firme la suerte de un país cuando se fía entera a una sola planta, y un micrófito o un zoófito, hoy el oídium, mañana la filoxera, pueden poner en grave riesgo su existencia. Hablando en términos generales, la agricultura castellana debe, a juicio mío, considerar divididas las tierras que actualmente destina al cultivo de granos en cuatro partes: sembrar la una de trigo y cebada, alternando con veza y algarroba; ir plantando de viña otra cuarta parte, y adehesar las dos restantes a fin de obtener pastos naturales si no se atreve a convertirlas desde luego y de una vez en prados artificiales, de secano o de regadio, según las circunstancias. De este modo, donde ahora obtiene una cosecha de trigo, cogerá tres con menos gastos: una de trigo, otra de vino y otra de carne y lana, superiores cada una a la actual, y dándose todas tres la mano por el vínculo de los abonos que la dehesa suministrará a los cereales, y del capital que encontrará en la viña. Entonces no tendrán ya que temer los trigos de Castilla la competencia de los americanos, aun cuando se reduzcan los tipos de adeudo en las aduanas, no digo a un derecho fiscal de 15 por 100, sino a un simple derecho de balanza como debe ser, y disminuyan considerablemente los gastos de transporte desde California por efecto de la ruptura del istmo de Panamá; y no tendrán que temerla porque, si Castilla, convencida como se van convenciendo las demás regiones de la Península, de que España no es ni 
puede ser el granero de Europa, pero que debe aspirar a ser su bodega, se limita a producir trigo para el consumo interior, no tendrá que enviar granos a las costas del Cantábrico; y como en los mercados castellanos alcanza el trigo, aun con el imperfecto sistema de cultivo que ahora practican, el precio natural a que los de América pueden expenderse en Bilbao sin el derecho arancelario protector, para llegar estos a Castilla tendrían que gravarse en 10 reales por hectolitro por gastos de transporte, y nadie los compraría, resultando más baratos los castellanos. Así, España comería el pan a un mismo precio: Castilla, con sus propios trigos, las provincias del Norte con los americanos, las de Levante con los rusos. Pero supongamos que todavía, encerrada en los límites de mi fórmula, la agricultura castellana produzca granos para la exportación, y entiendo por tal la que actualmente se hace de Castilla para surtir las fábricas harineras del Norte; pues aun en ese caso, afirmo que podrá competir ventajosamente con los trigos procedentes de California o de las Kansas. Y la razón es obvia: como habrá estrechado el cultivo y concentrado los elementos activos de la producción, tendrá abonos en abundancia, y, a los pocos años, hasta capital para embalsar arroyos o derivar a acequias de los ríos; con el mismo trabajo de ahora obtendrá mayor número de hectolitros por hectáreas, o de otro modo, producirá más barato: si el extraer el suelo una fanega de grano le cuesta ahora 35 o 40 reales, entonces le costará tan solo 25 , y tendrá sobrado con la diferencia para pagar el transporte por ferrocarril a Bilbao o a Santander aun con las tarifas vigentes, que no han de ser eternas.

Acaso se dirá que esto que propongo es retroceder en el camino andado por consecuencia de la desamortización. Cabalmente, solo que, como el camino andado ha sido vicioso, retroceder aquí es adelantar; hay que dar al trigo únicamente lo que es del trigo, y restituir al monte y a los pastos lo suyo que les tienen injustamente usurpado los cereales; hay que retirar a estos la inmensa superficie de 
dehesas y montes roturados que en estos últimos quince o veinte años se ha arrebatado imprudentemente a la ganadería y al arbolado. La venta de bienes nacionales provocó un desarrollo anormal y extraordinario del cultivo cereal, estrechó la zona de pastos, perturbó el curso regular de los hidrometeoros, enflaqueció a la ganadería, dobló los impuestos, y quitó a la agricultura casi todo el capital flotante de que disponía. Antes de que los labradores acabaran de pagar los plazos, el suelo ha sido arrastrado por aguaceros al mar o al fondo de los valles, o se ha esterilizado por falta de abonos, a causa del repentino desequilibrio establecido entre la superficie labrada y la de pastos, y el labrador, empobrecido y sin recursos, ha tenido que abandonar sus fincas a los logreros o al fisco, y cuando no, ha quedado como los antiguos hidalgos de la decadencia, figurando con centenares de hectáreas en los amillaramientos, y, sin embargo, sumido en la miseria. Lo repito: no hay más remedio que retroceder. ¿De qué ha servido, proteccionistas, para evitar este desenlace, la protección del 22 por 100 que al presente rige? Más aún: ¿de qué ha servido la prohibición que rigió hasta poco antes de 1868? Mal que os pese, tenéis que confesarlo: no ha aliviado en lo más mínimo la suerte de la agricultura, ha sido impotente para contener la emigración, y, en cambio, ha matado de hambre miles de soldados nuestros en Cuba y ha traído crisis alimenticias desastrosísimas sobre nuestra Península. ¡Y se nos habla todavía de protección! No está, no, en la protección el remedio a los males que padece nuestra agricultura: tienen estos raíces más hondas que las que puede extirpar la protección; aunque produciría el efecto de una gota de bálsamo vertida en el estanque del Retiro.

Quede, pues, sentado: 1. ${ }^{\circ}$, que Castilla puede cultivar cereales dentro de ciertos límites, aun después de la reforma arancelaria; y $2{ }^{\circ}$ que, aun antes de que esta sobrevenga, Castilla ha principiado a restringir el cultivo cereal y a introducir otro en lugar suyo, a fin de encerrarse en aque- 
llos justos límites dentro de los cuales puede ser remunerador. Pero yo quiero tener por inexactos y fantásticos todos mis cálculos; yo quiero suponer que es insostenible la competencia desde el momento en que se rebaje el arancel y desciendan a fiscales los actuales derechos protectores. Pues, señores, aun dentro de este supuesto, yo afirmo que la reforma arancelaria es un acto de justicia y de conveniencia para la inmensa mayoría de los españoles. Y la razón es obvia. A las provincias del interior, que solo producen cereales para su consumo, la cuestión de protección o de libre cambio les es indiferente (en cuanto productoras, entiéndase bien, no en cuanto consumidoras), porque, aun cuando dejáramos enteramente francos los puertos de la Península a los trigos del Far West, es seguro que no habrían de penetrar en el corazón de la Mancha por ferrocarril y caminos de herradura para hacer la guerra a los trigos indígenas en su propia casa. Las provincias a quienes puede interesar las cuestión de la libertad de los cambios son aquellas que tienen sobrantes. $\mathrm{Y}$ las provincias que tienen sobrantes son solo cuatro o cinco. Ahora yo pregunto: porque cuatro o cinco provincias se obstinen en conservar un régimen agrícola que ellas mismas confiesan que es ruinoso, jes justo hacer pagar las consecuencias a las 15 o 20 provincias del litoral que producen menos de la mitad del trigo que necesitan, y a las islas de Cuba y Puerto Rico, que no producen una sola espiga? ¿Es justo consentir que aquellas cuatro o cinco provincias, con el mismo error con que a sí mismas se arruinan y empobrecen, expulsen del litoral a la población trabajadora, arrojándola sobre las playas de África y América? ¿No ha de considerarse más bien la reforma arancelaria como un medio coercitivo, pero educador y legítimo, que apresure la transformación tan deseada y tan necesaria de la agricultura castellana?

Pues todavía no es esto todo. Todavía en aquellas cuatro o cinco provincias que producen sobrantes de granos para la exportación hay una masa de gentes a quienes inte- 
resa la reforma; las cuatro quintas partes de su población viven del trabajo mercenario, carecen de propiedad, ganan su sustento labrando los campos de la quinta parte restante, o bien son menestrales que sirven al labrador en sus diferentes oficios: como productores, no afectan al salario que reciben las oscilaciones del mercado, porque el mismo jornal cobran cuando el trigo va a 40 resales la fanega que cuando se cotiza a 60; pero como consumidores, interésanles los precios bajos, porque entre 40 y 60 reales va la diferencia de poder dar a sus hijos tres panes cada día en lugar de dos; esto sin contar con que el cultivo de viñas y arbolado, añadido al de cereales, acrecienta la demanda de trabajo y contribuye a que el jornalero tenga ocupación segura todo el año. ¿Y sería justo sacrificar las cuatro quintas partes de la población de Castilla la Vieja por consideración a la quinta parte restante?

Hay más: todavía de esa quinta parte hemos de descontar un gran número de propietarios, la mayoría, seguramente, a quienes la protección arancelaria no sirve absolutamente de nada. De igual suerte que los beneficios de la protección que se dispensa a los azúcares peninsulares no alcanzan directa ni indirectamente a los cosecheros de caña de Andalucía, sino que van a parar íntegros al bolsillo de una docena de capitalistas, dueños de ingenios, así la protección de los trigos castellanos no llegan a sentirla los labradores: la reciben los acaparadores de granos, que casi nunca proceden por vía de compraventa, sino por anticipos de dinero a pagar en especie, para gastos de recolección o atrasos de malas cosechas; reciben esa protección los especuladores extranjeros que, en el momento de la cosecha, compran las existencias en grandes masas y a precios ínfimos, pudiera decirse que al precio que ellos quieren ponerle, exhaustos como están de recursos los labradores a raíz ya de la recolección, para vendérselo a ellos mismos pocos meses después, en pequeñas partidas, para comer y para sembrar, con un alza de 30 o 40 por 100, alza artificial, naci- 
da exclusivamente del arancel, que concede gratuitamente el monopolio de la venta a los especuladores, en el hecho de hacer imposible la afluencia de cereales extranjeros que sostendría cierto equilibrio entre los precios de verano y los de invierno. De manera, señores, que el legislador se ha propuesto, con la mejor buena fe del mundo, prestar un servicio a los labradores, y ha logrado lo que era natural, pues sucede lo mismo siempre que se emprenden caminos tortuosos y contrarios a la justicia, efectos contraproducentes: encarecerles los medios de subsistencia, hacerles más difícil la vida y constituir el arancel en una especie de sequía permanente, contra la cual no queda ni siquiera el recurso de las rogativas, porque hemos visto no ha mucho al Reverendo Obispo de Barcelona bendiciendo al proteccionismo desde la cabecera de una mesa. Y yo pregunto: para proteger el interés egoísta de unos cuantos logreros, fabricantes de hambres artificiales y ministros de la muerte, acaparadores de campanarios, negociantes extranjeros y fabricantes de harina, ¿es justo que matemos de hambre a los cubanos, a los obreros catalanes, a los menestrales españoles, y que a los mismos que han producido a fuerza de sudores y angustias el trigo les obliguemos a comerlo a doblado precio, y a pagar de este modo indirecto una contribución que es la más inicua de las contribuciones más inicua todavía que la misma contribución de sangre?... 

Discurso pronunciado en el meeting librecambista sobre la

"URGENCIA DE LA REFORMA ARANCELARIA"

Celebrado en el Teatro de la Zarzuela en Madrid el día 26 de junio de 1881 



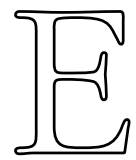

L SR. COSTA: Señoras y señores: antes de entrar en materia, debo hacer una manifestación: la considero necesaria porque temo que mi lenguaje sea demasiado vivo, y que los adjetivos que emplea en la impugnación adolezcan de exceso de relieve y de colorido. Al combatir a los proteccionistas como proteccionistas, entiéndase que los respeto como hombres, como patriotas y como trabajadores; combato sus doctrinas y sus procedimientos porque los considero injustos y ruinosos; pero respeto su convicción y sus intenciones, porque las estimo puras y honradas. Para mí, agricultores y fabricantes, proteccionistas y librecambistas son agrupaciones de hombres y clases sociales que profesan distintas opiniones con la misma sinceridad y buena fe los unos que los otros. Es más: el hecho solo de que marqueses y condes pongan su firma al lado de las firmas de los obreros de las fábricas para solicitar reformas protectoras en los aranceles de aduanas, confundiéndose en una común aspiración y en un mismo derecho los descendientes de los antiguos señores y los descendientes de los antiguos vasallos, representa a mis ojos un progreso inmenso en que ni soñar pudieron siquiera los españoles del siglo pasado: los proteccionistas no piden ya privilegios en el aire, a título de nobles, es decir, de exentos del trabajo y haraganes por derecho divino, como en la Edad Media, sino a título de trabajadores, y esto solo envuelve toda una revolución en las ideas y es una señal de los tiempos. Lo que hay es que no se conten- 
tan con lo que trabajan ellos y sus obreros, y por un género de tiránica accesión, cuyo estudio recomiendo al distinguido historiador de la propiedad, señor Azcárate, quieren acumular al fruto de su sudor el fruto del sudor ajeno, y monopolizar el honroso dictado de productores, como si ellos solos fuesen las abejas obreras de la gran colmena social, y los demás fuéramos a manera de zánganos, a quienes sería bien negar el agua y el fuego. (Aplausos). Si el proteccionismo envuelve alguna culpa, esa culpa alcanza tan solo a un corto número de personas que piden protección con plena y clara conciencia de lo que piden; alcanza a un corto número de fabricantes de tejidos, de harinas y de azúcar, y a unos cuantos navieros; sin contar, por supuesto, los contrabandistas, partidarios, como es natural, del proteccionismo (aplausos), sobre todo, los contrabandistas de Gibraltar, que con las fortunas que labran a costa del sudor de los labradores españoles podrían subvencionar espléndidamente a los oradores proteccionistas si estos no fueran, como son, al igual que los oradores librecambistas, gentes honradas que defienden su sistema por convicción y sin que tenga que reprocharles nada la conciencia.

Esto, en primer lugar. Por otra parte, median deberes de humanidad que nos obligan a hablar con cierto respeto del proteccionismo. A los moribundos, aunque hayan sido nuestros perseguidores y tiranos, hay que tratarlos con clemencia, porque los protege la religión del sepulcro; y el proteccionismo, que un día lo fue todo, está agitándose en las últimas convulsiones de la agonía, y preparándose a confundirse con la nada: los rabiosos esfuerzos que hace por recobrar la perdida salud, las amenazas llenas de hiel que fulmina contra nosotros creyendo el inocente que puede aún volver a ser lo que fue hace 20 años, más que odio, deben inspirarnos lástima y compasión, como nos la inspira el tísico, que la víspera de su muerte cree más cierta que nunca su curación, y toma disposiciones para llevar a cabo los magníficos proyectos con que ha soñado. (Grandes aplausos). 
Así como han ido cayendo de su cuerpo jirones de la púrpura con que se cubría el proteccionismo, rey un día de la producción y del mercado, han conocido todos su deformidad y lo torcido de sus intenciones, y se han apartado de él con horror y lo han denunciado a la sociedad como un foco de infección y de miseria. A las pomposas declamaciones con que trató de ensalzar sus excelencias y virtudes, contestaron los liberales con argumentos y con axiomas; a sus insultos, con hechos y con números. Lanzó orgulloso tremenda acusación contra los librecambistas, diciendo que eran unos cuantos abogados (cosa no extraña, siendo oficio de los abogados defender la justicia en todas sus manifestaciones), que ninguna riqueza producían, y los abogados contestaron que ellos pagan 2000000 de contribuciones al año, al paso que los fabricantes de tejidos no satisfacen sino millón y medio, es decir, que los abogados producen más riqueza que los tejedores catalanes. Denunciaron a los vinicultores andaluces como productores insignificantes, porque se atrevieron los muy insolentes a reclamar la negociación de tratados con algunas naciones extranjeras, y los vinateros andaluces contestaron que la sola ciudad de Jerez, que ni siquiera es capital de provincia, paga más contribución que Barcelona, emporio de la industria catalana y centro oficial del proteccionismo. Motejaron a Madrid llamándolo corte de vagos y holgazanes, que vivimos a expensas de los catalanes, chupándoles la sustancia en forma de impuestos y de contribuciones, y al comercio madrileño, que es librecambista, como formado por unos cuantos tenderos de mala muerte, y Madrid contestó con cifras demostrando que paga doble contribución industrial y de comercio que Barcelona, y que las cuatro provincias catalanas contribuyen menos por ese concepto que la sola villa de Madrid, toda vez que las cuatro provincias catalanas, incluyendo en el cálculo a Barcelona, Tarraga, Reus, Olot, Sabadell, Manresa, Gerona y Tarragona, tributan en junto por subsidio 21 millones y medio al año, al 
paso que la sola villa de Madrid paga por igual concepto 25000000 . Buscaron alianza y protección en los agricultores extremeños, elevando una petición al Gobierno hace dos años en solicitud de que se elevasen los derechos protectores sobre los cereales, a fin de que los de Extremadura pudieran atravesar la Península y abrirse mercado en Cataluña, y los labradores extremeños han contestado, por órgano de los de Las Brozas, manifestando al Congreso agrícola celebrado el pasado mes que la protección que ellos necesitan es franquicias aduaneras en las demás naciones, a fin de poder dar a conocer en ellas sus productos. Acudieron en demanda de unión y de auxilio a los cosecheros de granos de Castilla, a fin de que combatiesen con ellos los tratados con Francia e Inglaterra, y los cosecheros de granos de Castilla, lo mismo que los de toda España, que se van persuadiendo de que el proteccionismo es una injusticia y una infracción de las leyes universales del mundo natural, y van sustituyendo por esto a toda prisa el cultivo cereal por el arbustivo, contestaron votando por unanimidad, sin que un solo individuo discrepase, en el Congreso agrícola que conviene celebrar tratados con Francia, con Inglaterra, y además con los Estados Unidos. Recurrieron a los ganaderos, y los ganaderos les contestan reconviniéndoles, como en frase elocuente les reconvenía el Sr. Pedregal, de haber provocado represalias por parte de Inglaterra, que acaba de cerrar sus puertos al ganado vacuno de Galicia, y de preferir a las lanas de sus rebaños las de Australia y de Buenos Aires, entradas amañadamente como de nación convenida, por cuya razón no les consumen más de la sexta parte de las que ellos producen, correspondiendo las cinco sextas partes restantes a las demás provincias de España, donde la industria lanera no es proteccionista. Dirigiéronse a la industria de salazón de puerco, indicándole el arancel como un medio de sostener la competencia mortal que le hacen aquellas compañías colosales de Chicago, y la industria de salazón de puerco contestó que lo que ella 
necesita para poder competir con las carnes americanas es que se le permita introducir, como primera materia, maíz americano, sin trabas aduaneras. Aguardaron defensa de parte de los ingenieros industriales, y la Asociación de Ingenieros Industriales, saliendo a la defensa de los constructores de máquinas, elevaron una petición al Gobierno con la pretensión de que la introducción de hierro bruto no se grave con un derecho superior al derecho con que están gravadas las máquinas mismas, que es inferior al de la balanza. Acordaron no votar en las próximas elecciones de diputados a Cortes a los candidatos que no declaren públicamente que combatirán cuantas reformas liberales arancelarias proponga el Gobierno, y ya las revistas especiales de agricultura han principiado a agitar la idea de que los labradores, que son diez contra uno, exijan terminante declaración en sentido contrario de los candidatos rurales. Llamaron a las puertas del fisco, tratando de persuadirle de que con los tratados descendería la renta de aduanas, y el fisco les contestó, estadística en mano, que, a consecuencia del convenio celebrado con Francia en 1877, la renta de aduanas, lejos de menguar, había crecido en dos años desde 67 millones a 81, es decir, más de un 20 por 100, en demostración de que aquella renta, lo mismo que la de correos y que tantas otras, lo mismo que el producto de ferrocarriles, se parece al agua en la rosca de Arquímedes, que sube cayendo; rebajáis los tipos de adeudo y aumenta el rendimiento; que, por esto, yo grabaría en la puerta del Ministerio de Hacienda a guisa de simbólico blasón* una rosca de Arquímedes con el mote aumentar rebajando (aplausos), para que no lo perdiesen de vista estos famosos hacendistas españoles que lo último que ven es lo que más cerca tienen de los ojos, como quien no ha aprendido toda-

* "a guisa de simbólico blasón": texto añadido a mano por Joaquín Costa en el ejemplar conservado en el Archivo Histórico Provincial de Huesca, АHPH (N. del E.). 
vía a leer entre líneas en el gran libro de la realidad. Viéndose también desairados por esta parte, quisieron agitar la opinión con meetings, y la opinión les ha contestado con más de 200 peticiones procedentes de todas las provincias de la Península, y suscritas por millares de hacendados y de labradores, reclamando con instancias que se abran nuevos mercados a nuestros caldos. Ante esta manifestación coreada de la opinión nacional, se estrecharon en torno de Barcelona para formar el cuadro, y del seno mismo de ese cuadro surgieron voces poderosas en favor del librecambio, y la Asociación de Agricultores de Manresa representó la urgencia de un tratado de comercio con Inglaterra, y lo reclamaron asimismo en diversas instancias cosecheros de Lérida y de Tarragona y los inspiradores del Ampurdanés; y cuando el Instituto Agrícola de San Isidro, por efecto sin duda de una sorpresa, dirigió al Gobierno una petición contra los tratados, el presidente de la comisión que representa a dicho centro en Madrid, cerca del Gobierno, Sr. Marqués de Monistrol, se negó con noble entereza a presentar dicha petición, por no hacerse cómplice de un acto que a su juicio envolvía la ruina de la patria; y cuando se ha sabido que el Instituto fundaba su reclamación en que casi todos los vinos españoles se quedan por bajo de los 14,86 grados alcohólicos Gay-Lussac, y que, por tanto, podían entrar en Inglaterra sin necesidad de negociar reducción alguna de la escala alcohólica, la Asociación de Ingenieros Agrónomos, cuyo digno Presidente me está oyendo, les arguyó de inexactitud, demostrando con los datos oficiales de la Exposición vinícola celebrada en Madrid hace cuatro años que las tres cuartas partes de los vinos españoles exceden de aquel tipo alcohólico. Representaron en queja a los labradores, asegurando que con el tratado anglo-español iban a convertir a España en una factoría de Inglaterra, por causa de los tejidos, y los labradores contestan que lo que ellos buscan con dicho tratado es convertir a Inglaterra en una factoría de España por medio de los vinos. Pusieron 
el grito en el cielo, jurando que vamos a dejar desiertas sus fábricas y a sus obreros sin trabajo, y nosotros contestamos diciendo que lo que vamos a hacer es reanimar la industria por excelencia nacional de los españoles, la industria agrícola, que no pide injustas ni gravosas protecciones, a fin de que encuentren trabajo en su país aquellos 130000 españoles que hay en la América del Sur, ligados a una semiesclavitud afrentosa, y ansiando el regreso a su país, y esos infortunados 100000 españoles de Argelia que, en la cruda lucha por la existencia que tienen que sostener en su país, huyen de su enemigo el proteccionismo, que los ha vencido y los arroja a playas inhospitalarias donde la bandera nacional no puede protegerlos contra las incursiones de cabilas feroces que los saquean y degüellan, abandonados por un país que ha demostrado su incapacidad para gobernar colonias y proteger y garantir la vida de los extranjeros que se acogen a su pabellón (grandes aplausos), en el instante mismo en que se anexionaba hipócritamente a Túnez, a pretexto de incapacidad de su gobierno, a pesar de que el Gobierno del Bey no ha consentido nunca hecatombes y matanzas como la trágica matanza de Saida. Y así rechazados los proteccionistas por todos y de todas partes, recluidos en soledad amarga, faltos de orientación y brújula, perdida la serenidad y la calma, pusieron su última esperanza en el Gobierno, y joh tristes decepciones de la vida! se encontraron con que la opinión había impuesto un Gobierno partidario del librecambio, y comprometido solemnemente a establecer en todo su vigor la reforma arancelaria de 1869. Presa con esto de la desesperación, tan mala consejera, ensayó el expediente de las amenazas, y por órgano de cierto Diario, cuyas intemperancias y cuyas excentricidades son ya proverbiales, conminaron embozadamente con una separación y con un rompimiento, pero no faltó entonces quien recordase que en 1869 el general Prim amenazó a sus paisanos, los catalanes, con los cañones de España si no aceptaban voluntariamente la reforma 
arancelaria (aplausos). Por manera, señores, que al proteccionismo, acosado por todas partes, herido en sus entrañas de descomposición, sin valor ya para mirar cara a cara a sus enemigos, anatematizado y desahuciado, sintiendo próxima al desenlace la comedia que ha representado durante tantos siglos, no le queda ya sino pedir que le sean perdonadas sus muchas faltas y ponerse bien con Dios, y he aquí por qué os decía que, sin cesar de poner los medios para que cuanto antes acabe de expirar, debemos tratarlo, sin embargo, con aquella magnanimidad y consideración con que el pueblo español trató siempre a los vencidos, imitando el ejemplo nobilísimo del Alcalde de Zalamea, el cual, si bien ahorcó al capitán D. Álvaro de Ataide, lo ahorcó con muchísimo respeto. (Risas, aplausos).

Todavía le asiste al proteccionismo una tercera razón por la cual se recomienda a nuestra benevolencia, y es que no deben extremar los hombres el castigo cuando Dios favorece al pecador con el beneficio del remordimiento; y, señores, el período de agitación nerviosa en que ha entrado el proteccionismo, y que se traduce en ruidosos meetings y en artículos furibundos, es una consecuencia natural del estado de intranquilidad de su conciencia y del miedo que le causa la proximidad de lo que podríamos llamar el juicio final. El Sr. Aguilera nos decía, hace un instante, cómo en 1869 se pactó un convenio tácito entre proteccionistas y librecambistas, dando unos y otros en prenda lo que más estima tiene entre hombres honrados: la palabra. Los liberales, olvidando que al error no debe reconocérsele nunca derechos, que los doctrinarismos y los justos medios no son menos infecundos y nocivos en economía que en política (bravo), que las componendas y las transacciones no son admisibles ni siquiera como puente para pasar del mal absoluto al absoluto bien, olvidando que las demasiadas contemplaciones con lo existente fueron siempre perjudiciales para las reformas, concedieron un plazo de seis años a los industriales para prepararse a la nueva situación, fuese 
mudando sus procedimientos industriales, fuese liquidando y retirando progresivamente los capitales comprometidos en edificios, maquinaria, y demás. Hubo quien no se fio de ellos: con previsión exquisita, que los sucesos convirtieron en vaticinio, escribía en su voto particular el actual Presidente de esta Asociación que "no se podía explicar el empeño con que algunos defendían la subsistencia del antiguo Arancel durante seis años sino por la esperanza de dificultar y paralizar la reforma dentro de ese plazo" y pedía, en consecuencia, que la rebaja gradual empezara desde el primer año. La enmienda fue desechada: los seis años estaban a punto de trascurrir; faltaban días solo para que se decretara esa primera rebaja, cuando el proteccionismo, haciendo alarde de una ingratitud y de una deslealtad tan grandes como grande había sido la honrada candidez de los liberales, mintió a la santa religión de la palabra y no se avergonzó de recabar el decreto de 17 de junio de 1875, por el cual se suspendía la ejecución de la reforma de 1869, aprovechando uno de los momentos más angustiosos y terribles por que ha pasado nuestra patria: el momento en que estaba derramando torrentes de sangre y consumiendo su fortuna en las montañas de Cataluña y de Navarra por sacar incólumes su honra, su nombre, su porvenir y su dignidad. ¡Ah, señores! A aquel acto del proteccionismo, que solo podrán calificar los venideros cuando se hayan inventado nuevas palabras en el Diccionario, a aquel acto bochornoso del proteccionismo, yo solo le encuentro uno que sea semejante en nuestra historia: San Carlos de la Rápita. (Aplausos). Se comprende, por esto, que sientan en su pecho el torcedor del remordimiento y se confiesen ante su propia conciencia culpables y merecedores de castigo; se comprende que les infunda miedo la declaración hecha en ocasión solemne por esta Asociación, hace dos años, de que los proteccionistas se han incapacitado moralmente para reclamar en lo sucesivo nuevas transacciones y para que se otorgue ningún crédito a su palabra; se comprende 
que anden huidos de sí mismos, como el personaje bíblico, por no escuchar aquella voz terrible que resuena en lo más profundo de su ser, gritándoles: "Caín, ¿qué has hecho de tu palabra?"; se comprende, por esto, el clamoreo que levantan con sus meetings, imitando a los niños a quienes, por haber cometido una falta, se encierra en una pieza oscura, que gritan y lloran descompasadamente para acallar de este modo la voz acusadora de su conciencia y divertir el miedo poblando de ecos las sombras y ahuyentando los monstruos que les representa su fantasía. (Grandes aplausos). ¿Comprendéis ahora por qué os decía que, pues llevan en su propio pecado la penitencia, que, pues sienten clavado en su alma el dardo del remordimiento, debemos mostrarnos suaves y benignos en la palabra, máxime cuando el deber nos manda que seamos muy duros con ellos en las obras? (Risas y aplausos).

Hechas estas manifestaciones preliminares, puedo pasar ya a contestar algunas de las afirmaciones que se han hecho en los meetings proteccionistas, considerando particularmente el problema de la libertad mercantil desde el punto de vista de los cosecheros de vinos, que son, hoy por hoy, el opuesto fatal de los fabricantes de tejidos catalanes.

Y la primera queja que de estos tienen, y el primer cargo que tengo que formular contra la protección aduanera, es que con el actual régimen arancelario los labradores, a pesar de constituir en España mayoría, y de regir una Constitución que hace de igual condición a todos los españoles, pagan impuestos de que los industriales están exentos. Los industriales beben nuestro vino, no ya al precio a que lo da la Naturaleza, sino más barato, porque nos cierran los mercados extranjeros, y, por tanto, restringen la demanda; en cambio, nos obligan a vestirnos de sus telas, no ya al precio a que pueden producirse, sino más caras, porque cierran nuestro mercado a los tejidos extranjeros, que aumentarían la oferta; por manera que los agricultores pagamos impuestos que no satisfacen los industriales, sea al Estado, en 
forma de derechos de aduanas, sea al fabricante español, en forma de sobreprecio, sea a los contrabandistas o a las sociedades de seguros de contrabando, en forma de prima. Y por Dios, señores, es bueno que resulte ahora que los labradores somos pecheros de los fabricantes; que medio siglo después de haberse proclamado, junto con otras libertades y con otros derechos, la igualdad tributaria, resulte que los labradores pagamos dos contribuciones que apenas alcanzan a ellos; una por efecto de esa carestía artificial, en forma de sobreprecio, y otra directa, para mantener carabineros y cuerpo pericial en las fronteras; carabineros y cuerpo pericial que, al cerrar las puertas de España a los tejidos ingleses, cierran juntamente las puertas de Inglaterra a nuestros productos agrícolas, y cuyas bayonetas obran por esto a modo de lanceta que está picando constantemente las venas de 16000000 de españoles, para trasvasar su sangre en las venas de unos cuantos capitalistas, señores feudales del algodón y de la lana. (Grandes aplausos).

A esto los proteccionistas lo llaman patriotismo, lo llaman industria nacional. Yo me atrevería a encontrarle nombre más apropiado en el Diccionario, pero no quiero buscárselo; yo no quiero llamarlo como lo llama cierto Código que tampoco quiero nombrar, y no quiero nombrarlo, a pesar de que una de las Gacetas oficiales del proteccionismo, con catalana franqueza, por no decir con rudeza de almogávar, nos ha aplicado a los librecambistas el pintoresco calificativo de ladrones. (Risas). Lo que sí puedo decir, sin faltar a ningún género de conveniencias, es que la situación de los agricultores, enfrente de los industriales, obteniendo tarifas altas para sus productos y bajas para las primeras materias, o más claro, obligándolos a venderles barato y a comprarles caro, se parece a la situación de los indios de Cagayan, Visayas y otras provincias de Filipinas, condenados (hasta que se lleve a ejecución el decreto de hoy) al cultivo forzoso del tabaco, con prohibición absoluta de cultivar plantas industriales, y a vender al Estado el 
tabaco que cosechan al precio a que el Estado comprador quiere tasarlo, y obligados por otra parte a comprar al Estado, o a los traficantes a quienes el Estado protege, los artículos de comer y de vestir al precio que el propio vendedor quiera ponerles; esclavitud con máscara, afrenta del nombre español, por la cual nos maldecirán nuestros descendientes el día que tengan que luchar contra los indios alzados en armas por la libertad y por la independencia, como hemos tenido que purgar nosotros en Cuba errores de nuestros padres, que nos han costado 100000 soldados, muertos unos en los campos de batalla, heridos por las balas de los negros a quienes hemos tiranizado durante siglos, otros en los hospitales de sangre, por anemia o falta de alimentación, heridos de lejos por nuestros carabineros y fabricantes de harinas, en cuyos bolsillos hay que buscar más de la mitad de la sangre española derramada en los campos de la isla de Cuba. (Grandes aplausos).

La otra queja que los productores de caldos tienen de los productores de tejidos — pues ya, señores, el problema mercantil no se ventila como antes entre consumidores y productores, sino que se llalla planteado entre la industria agrícola y algunas ramas de la manufacturera-, el segundo cargo que traigo contra los fabricantes de tejidos es que, pretendiendo saber más en casa ajena que los vinateros en la propia, se metan a redentores de la vinicultura española, tratando de persuadir a nuestros labradores de que no les conviene sustituir el cultivo cereal por ningún otro (precisamente lo contrario de lo acordado por el Congreso agrícola, que es de suponer entienda más de estas cosas que los tejedores catalanes), y al Gobierno, de que sería ruinoso para nuestra producción de caldos plantar más viñas de las que se cultivan en la actualidad, por lo cual debe esforzarse en evitarlo desistiendo de toda negociación con Inglaterra, y, por otra parte, que si los ingleses no vienen a solicitar nuestros vinos, no es por efecto de la escala alcohólica, la cual no les perjudica en lo más mínimo, sino porque no 
están adaptados al gusto del paladar inglés; como los vinos franceses, por ejemplo. Respecto de este último extremo, han sido ya victoriosamente refutados: nuestros vinos comunes o de pasto, que es el punto de la cuestión, no se popularizan en Inglaterra ni hacen la competencia a los franceses en el mercado inglés porque el límite que separa los tipos de adeudo de un shilling y de dos shillings y medio por gallon (4 litros y medio) es de 14,86 alcohólicos, y mientras los vinos franceses se quedan generalmente por bajo de este tipo, los españoles lo exceden en el 75 por 100 de los casos, y todavía los vinos restantes, como la agricultura española no tiene capital para guardarlos y elaborarlos durante tres años, tienen que ser encabezados hasta los $15^{\circ}$ para que puedan resistir la travesía y no se maleen en el camino; con lo cual viene a resultar, en conclusión, que los vinos comunes españoles están gravados con dobles derechos que los franceses en las aduanas del Reino Unido, derechos que llegan al 100 y aun al 120 por 100 del valor del producto. ¿Qué necesidad hay de buscar otra explicación al hecho, por demás lógico, de que mientras Francia ha acrecentado su exportación de vinos a Inglaterra en un 1000 por 100 desde el tratado de Cobden-Chevalier, el comercio de vinos comunes españoles haya permanecido estacionario? Decía un orador del meeting proteccionista de Barcelona que ninguna falta hace negociar la reducción de la escala alcohólica inglesa porque, con tratado o sin él, con esa escala o con otra cualquiera, el mercado inglés tendrá que surtirse necesariamente en nuestras bodegas. ( $E l$ Sr. Vallés: "Tenía razón"). Si el señor interruptor entiende que yo no la tengo, creo que el Sr. Presidente le concederá con mucho gusto la palabra a fin de que pueda razonar su opinión y desvirtuar mi tesis. (Rumores. Muchas voces: "Que hable").

El SR. Presidente: Silencio, señores: la Presidencia está aquí para restablecer el orden. Si alguno de los señores asistentes a la reunión que tenga ideas contrarias a las que han 
emitido los oradores quiere usar de la palabra, tendremos mucho gusto en oírle; pero estoy dispuesto a no tolerar que se altere el orden ni se interrumpa al orador.

El SR. VAllés: Yo estoy dispuesto a sostener lo que he dicho.

El SR. Presidente: ¿Quiere S. S. la palabra?

El SR. VAlLÉS: Si se me permite, hablaré.

El Sr. Presidente: Tendrá S. S. la palabra cuando concluya el Sr. Costa.

El SR. Costa: Me felicito de que haya venido un señor proteccionista a, ilustrar el problema transcendentalísimo que estamos ventilando; y para que haya orden y claridad en el debate, voy a precisar las razones que he tenido para considerar el tratado anglo-español, más que como conveniente, como necesario para que la agricultura se mueva desahogadamente dentro de la órbita que le trazan las condiciones naturales y sociales de nuestro país.

En primer lugar, no es España la única región del mundo que puede surtir de vino a los ingleses: aun haciendo caso omiso de Francia, de Portugal, de Italia, de Grecia, de Hungría, de Argelia y aun de Australia, los Estados Unidos, acometidos repentinamente de la fiebre de los cultivos industriales, están ensanchando rápidamente la zona de viñedos, y se proponen inaugurar este año ya las importaciones de vinos en Europa; por manera que, si no nos apresuramos a posesionarnos del mercado inglés, acaso dentro de poco tiempo sea tarde y sobrevenga una crisis terrible, que no sería crisis tan solo para la agricultura, que sería crisis para la patria, sucediéndonos lo que está a punto de suceder, si Dios no lo remedia, con los azúcares antillanos, que el mejor día se van a ver imposibilitados de desembarcar en los puertos de la América del Norte, porque el proteccionismo español ha sugerido inmediatamente a los yankees la idea de cultivar por sí la caña de azúcar, como lo hacen cada vez en más vasta escala, preparando de esta manera la ruina, quién sabe si ya inevitable, de la isla de Cuba. (Sensación). 
Por otra parte, los vinos comunes españoles, que podrían expenderse en el mercado inglés a dos y medio o tres reales el litro, con los derechos de aduana se elevan a cinco o seis reales y a este precio ya no pueden consumirlos las clases obreras, y como no pueden consumirlos, se abstienen de pedirlos, siendo por esta causa insignificante nuestro comercio de vinos con Inglaterra, reducido al 1 por 100 de la total exportación. Y no quiero ocultar que tan desfavorable situación no se remediaría sino en parte con la nueva escala alcohólica, porque todavía con ella resultaría nuestro vino de pasto ordinario gravado con un derecho de 30 o de 40 por 100 del valor del producto, o más claro, con un real o real y medio por litro, y a esto hay que oponerse en la negociación del tratado anglo-español, porque con esa base el vino peninsular no desterrará el uso de la cerveza entre las clases obreras inglesas, como no lo ha desterrado el tratado anglo-francés de 1860; y nuestro comercio de exportación al Reino Unido no tomará el gran incremento que tenemos derecho a esperar y que necesitamos. Hay que conseguir una rebaja tal en las tarifas actuales, que el vino común no adeude más del 15 por 100 de su valor; hay que hacer además fáciles y desahogadas las transacciones, fijando un tipo de adeudo uniforme para todos los vinos que no excedan de $35^{\circ}$ o $36^{\circ}$ sykes, volviendo en esto al régimen anterior a 1860. Conseguida esta reforma, el porvenir de la vinicultura española quedará asegurado para mucho tiempo. Temen los proteccionistas que nos falten mercados si aumenta excesivamente la cifra de la producción actual. Pero ¿cómo han de faltar mercados cuando hay todavía media Europa que no sabe lo que es vino, y que se embriaga, diré mejor, que se envenena con bebidas alcohólicas que apagan la inteligencia y embrutecen al hombre? Hay que sustituir nuestras bodegas de vino verdadero a tantas fábricas extranjeras donde se elabora vino artificial que no tienen de español sino el nombre, y aun este adulterado: hay que crear agrupaciones de vinos con caracteres fijos y 
nombre conocido, por medio de una propaganda activa e incesante; hay que destronar a Francia del puesto que ha logrado conquistarse a fuerza de ingenio, de cálculo y de inmensos sacrificios; hay que llevar el vino a la mesa del obrero inglés, del obrero alemán y del trabajador ruso, para quienes es todavía artículo de lujo, inaccesible dentro de sus pequeños recursos; si no hubiera de pareceros esto una fantasía, os diría que hasta constituye parte de nuestro destino como pueblo y una especie de misión humanitaria y de obligación moral, a causa del lugar que ocupamos en el planeta, llevar la alegría de nuestro sol y de nuestro cielo en las olas de púrpura de nuestros vinos a los países nebulosos del Norte, democratizando ese rico caldo, extrayéndolo de la botella con etiqueta y del escaparate a través de cuyos cristales lo contemplan las masas como un ideal inasequible, para enviarlo en lagares ambulantes y derramarlo en los barrios donde habita el pobre, al mismo precio casi a que se expende en el país productor. Eso que cuando la Guerra de Crimea principió a ser un arroyo, ha de convertirse en caudaloso río que ascienda del Mediodía al Norte y haga retroceder aquel brazo de mar de la cerveza que desciende potente desde el Norte y hace progresos hasta entre los obreros franceses desde que los vinos comunes han alcanzado precios tan elevados. Hay más: hay que producir vino hasta para el trabajador español, que se ha visto obligado a mermar su antigua ración desde que la exportación ha encarecido el producto en un 100 por 100. Si el mundo no está dispuesto a consumir más vino del que ahora producimos, si no le conviene a España multiplicar los viñedos, ¿cómo en el corazón mismo de Cataluña, donde tanto se sabe, acaba de constituirse la semana pasada una compañía anónima para plantar de viñedo terrenos incultos de Aragón y emprender en vasta escala el comercio de vinos muy tintos y alcohólicos, compañía que, según han dicho los periódicos estos días, cuenta con un capital de 40000000 de reales, procedentes de Cataluña y del extranjero? 
Es fuerza que haga ya punto; pero antes de retirarme, quiero dirigir, no me atrevo a decir una excitación, diré un voto, al Gobierno. Lo elevó la opinión, sedienta de libertad y de reformas, porque creía que en los actuales instantes nadie como él podía realizarlas; pero con la inacción, los Gobiernos se enmohecen y la opinión sufre un desencanto. Ha entrado España en una era eminentemente positiva, que no se paga de palabras: está ya harta de discursos y hambrienta de obras, y principia a cansarse de esa brillante plana mayor de oradores y de retóricos que sienten y dicen tan bien lo que después han de practicar tan mal. A la generalidad del país no le importa que esté en el poder Fulano o Zutano; lo que le importa es que gobierne, y gobernar no es pasar por el banco azul, hablar, cobrar y dimitir: es obrar, y la historia, a los Gobiernos que pasaron no los conoce por sus programas ni por sus manifiestos, sino por sus obras. Un Gobierno mudo, pero activo y reformador, un Gobierno sin lengua, pero con brazos: este es hoy por hoy el ideal político de nuestro pueblo. (Aplausos). ¿Os parece que vale la pena agitar al país con elecciones, reunir en dos Asambleas la flor de la nación, sostener empeñadas batallas con los adversarios, consumiendo tesoros de ingenio en cien debates, para que en fin de cuentas, Cánovas o Sagasta o Castelar o Ruiz Zorrilla sean Poder toda su vida, y se despidan luego del mundo sin dejar nada tras de sí, y diciendo como el Rey Sol: "Ha terminado la comedia"?

El Gobierno actual, cuyos individuos en la oposición lo hicieron esperar todo, porque todo lo prometieron en punto a libertad de comercio, vacila y titubea como sobrecogido de espanto en presencia de la agitación proteccionista catalana, y es preciso alentarle para que no retroceda. Sepa que detrás de él estamos el 90 por 100 de los españoles, que somos agricultores o que ejercemos industrias no protegidas: tenga presente que a la agricultura, la reforma arancelaria más le favorece que le daña, porque, si bien el actual derecho protector de 16 por 100 sobre los cereales ha 
de descender a derecho fiscal de 15, ese 1 por 100 de baja, lo mismo que el uno y cuartillo que pierde en los ganados, se compensa sobradamente con el 20 por 100 que gana en los tejidos de algodón con que se visten los labradores, y por añadidura conquista para sus producciones el gran mercado de Inglaterra. (Aplausos). Pero no es todavía por esto por lo que la agricultura repugna la protección: aunque la protección hubiera de beneficiarle, antes que medrar a poder de privilegios y de injusticias, antes que encarecer artificialmente sus productos, y enriquecerse con la sangre de los pobres, y matar de hambre a los obreros catalanes, renunciaría a la protección y se contentaría con una ganancia mínima; porque los labradores españoles ponen por encima de su provecho personal el provecho de la patria y el bien de la colectividad, y jamás han pensado en sacrificar a un interés egoísta y pasajero los fueros de la humanidad y los intereses eternos de la justicia. (Grandes y prolongados aplausos). 
Discurso pronunciado en el meeting de la Asociación para la Reforma Liberal de los Aranceles de Aduanas

Celebrado en el Teatro de Apolo de Madrid el día 8 de enero de 1882* 



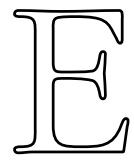

L SR. COSTA: Señoras y señores: No me será difícil complacer al Sr. Presidente en la recomendación de brevedad que en la introducción al meeting nos ha hecho, pues me hace temer la glacial temperatura de este sitio que antes de pocos minutos me habré convertido en un sorbete. Por lo pronto, como las ideas se empalman y concatenan unas a otras por cierta fatal asociación, tanto frio aquí dentro y tanto calor y tarde tan primaveral allí fuera, han despertado en mi memoria el cuadro de nuestra política presente: tan vivo anhelo y tan caluroso entusiasmo en nuestro pueblo por las reformas, y tanta frialdad y tanto quietismo en el Gobierno para llevarlas a cabo. Pocas veces se ha visto, con efecto, en Espa-

* Costa lo incluyó en Estudios Jurídicos y Políticos y le puso por título "Los aranceles de aduanas y la política con Portugal y América". Además estableció un índice temático tras el título, aunque no introdujo ningún epígrafe en el texto: "Relación entre las Aduanas y la independencia nacional, según el proteccionismo. El libre cambio y la libre entrada. Armonía entre la economía doméstica y la economía nacional.-España, nación americana: atracción de la América española hacia su antigua metrópoli: parte que tuvo en su separación el proteccionismo: reciente política de este con Venezuela: reconstitución de la nacionalidad hispano-americana por el libre-cambio.-Portugal, como parte de esta nacionalidad: su historia, lo mismo que la de Aragón, es un capítulo de la historia de España: ilogismo de las aduanas en la frontera hispano-lusitana: la unión ibérica por la Liga aduanera.-Una excitación a los partidos políticos: España anhela gobiernos que cuenten su vida por reformas y no por años". (N. del E.). 
ña, si es que se ha visto alguna, tantos partidos y fracciones políticas como hoy se disputan los favores de la opinión; pero pocas veces también, estoy por decir ninguna, se les ha visto tan unánimes en saludar gozosos y llenos de esperanzas el advenimiento al poder del partido fusionista. Jamás en nuestra historia se había visto tanto deseo, tanto empeño, tantas condescendencias, diré más, tantos sacrificios por parte de las oposiciones, porque el partido gobernante prosperase e hiciese prácticos y vivideros los principios de la libertad política, y satisficiese las aspiraciones del país, implantando las reformas por que suspira España y que ostentan en su programa todos los partidos, incluso el imperante; pero nunca tampoco se había visto tanto empeño por parte de un Gobierno en desoír los clamores de la opinión, en renegar de sus antecedentes y de sus compromisos, en desencantar a las oposiciones, en poner a prueba la paciencia del país, y en correr ciegamente a un cobarde y vergonzoso suicidio. El juicio por jurados, el matrimonio civil, la abolición de la esclavitud, la supresión de la ley de imprenta, la libertad de enseñanza, la ampliación del sufragio electoral, el fomento de la marina de guerra, la canalización para la agricultura, la libertad de comercio, todas esas reformas y todos esos empeños por consideración a los cuales puso la opinión el poder en manos del actual Gobierno, se han disipado como un sueño al soplo letal de esa política mezquina que quiere parecerse a la política de la prudencia, y que no es en realidad más que la política del miedo, política empírica de emplastos y de tópicos, de rutinas y de componendas, de disidencias bufas y de complacencias serviles a merced de los prohombres de villa, sin idea que la sublime ni plan fijo que la encauce, y que no se distingue de la política mercantil de campanario sino en el más alto precio a que se cotizan las voluntades, y en el mayor ámbito que mide el salón de conferencias respecto del soportal de un cacique de aldea. (Aplausos). 
¡La reforma arancelaria! ¡Quién hubiese dicho hace pocos años al Sr. Camacho y al Sr. Albareda y al Sr. Sagasta que, doce meses después de ocupar el poder, seguiría rigiendo todavía aquel inicuo decreto de 17 de julio de 1875, por el cual una dictadura enemiga del país entregó el país atado de pies y manos a merced de unos cuantos industriales divorciados de su patria! ¿Quién hubiese dicho a aquellos denodados campeones del librecambio que harían mella en su espíritu las preocupaciones internacionales de los proteccionistas de buena fe, y que buscando transacciones y componendas entre su conciencia y el error, entre sus convicciones y sus miedos, habrían de proyectar una reforma mestiza, informada en el absurdo principio de la reciprocidad, y que todavía sobre esa reforma, que representa un triunfo para el proteccionismo, arrojarían la losa mortuoria de un decreto de suspensión, dando de hecho la razón a los proteccionistas, que nos pronostican nada menos que la servidumbre y la muerte de la nacionalidad si abrimos a la riqueza extranjera un resquicio siquiera en nuestras aduanas!

Yo voy a ver si acierto esta tarde a deshacer ese error en uno de sus dos aspectos, ya que el Sr. Azcárate ha de tratarlo en el otro; yo voy a contestar esos argumentos o esas declamaciones en que tanto hincapié han hecho los proteccionistas en sus meetings del año pasado, que parecen haber atemorizado al Gobierno, y que todavía no han sido contestados de un modo directo en estos meetings; voy a considerar el problema arancelario desde el punto de vista del patriotismo y de nuestra política internacional, para sacar por conclusión la necesidad de no dilatar la reforma y de retrotraer sus efectos a 1875, ya que a 1869 no sea posible. Vosotros sabéis que uno de los recursos de que más frecuentemente echa mano el proteccionismo, y uno de los sentimientos, nobles y legítimos, que con más probado éxito explotan en sus meetings los oradores proteccionistas, abusando cruelmente de la candidez de sus oyentes, es el 
sentimiento de la patria. Según uno de ellos, los librecambistas somos enemigos de la prosperidad, de la independencia y de la integridad de la patria: pretendemos convertir a España en una factoría de Inglaterra, "humillando el orgullo nacional que nos legaron nuestros abuelos, los autores de la Constitución de Cádiz". Comparaba otro elocuente orador proteccionista a sus correligionarios con los patriotas del año 8, y a los librecambistas con los afrancesados, toda vez que, "si entonces se luchaba por la independencia del suelo patrio, hoy combaten las dos escuelas en el campo de la economía, defendiendo la proteccionista la santa causa del trabajo nacional". Añadían otros que "el fuego que alienta sus convicciones proteccionistas es el sentimiento de independencia"; que "no deben hacerse concesiones a Inglaterra, que nos arrebató a Gibraltar"; que "un tratado con aquella nación nos reduciría a la condición de indios de Europa, explotados y avasallados por la potente Albión"; que nuestras doctrinas "entregarían al extranjero esta sagrada tierra que nunca sus armas supieron conquistar"; que "para ponernos al nivel de los pueblos más avanzados, hay que vencer ante todo al enemigo interior, cuyas imprudencias tienen, por el resultado, mucho de traiciones, por cuanto favorecen los intereses exteriores", etc.

Me contristan, señores, estos extravíos de lenguaje; pero no esperéis que los conteste en el mismo tono declamatorio y patriotero, a pesar de que no ignoro cuan fácil tarea es cincelar artísticos y brillantes períodos y electrizar los ánimos y conmover a las gentes hiriendo la vena, siempre pronta a correr, del sentimiento patrio: no he venido a hacer alardes de retórica ni a pronunciar un discurso, antes bien, a repetir los votos que tantas veces tengo hechos, y que no me cansaré nunca de hacer, porque pase pronto ese diluvio de palabrería hueca en que se disipa nuestra alma y se esterilizan las nobles cualidades que resplandecen en nuestra raza. Pero me irrita toda usurpación, y no puedo llevar en paciencia que los proteccionistas exploten la rica mina 
de las susceptibilidades nacionales, y quiero desenmascararles: yo no puedo consentir que vendan cariño y protección a una patria a quien han empobrecido y desangrado: cuando escucho esas protestas de cariño filial, cuando les oigo proclamarse con tanto calor los únicos representantes de la prosperidad y de la independencia y del engrandecimiento de nuestra patria, me parece que están clavando el afrentoso inri sobre la cruz donde la tienen postrada y abatida los pecados del sistema protector. ¡Abajo ya las caretas! Sois vosotros, proteccionistas, los enemigos de la prosperidad de España, los que sacrificáis en el altar de vuestros apetitos y de vuestras concupiscencias el presente y el porvenir de nuestra patria, los que la tenéis pobre, enfermiza, enflaquecida y débil, y los que atentáis con esto a su integridad y a su independencia: sois vosotros, proteccionistas, los que la tenéis aislada, perdida en un rincón del globo, extraña al juego de la política internacional europea, como si vuestro malhadado sistema fuese una máquina neumática para hacer el vacío en derredor de España. Lo habéis adivinado: existe, con efecto, un vínculo, y vínculo estrecho, entre el problema del comercio exterior y el problema de la existencia y de los destinos de nuestra raza; pero ese vínculo viene fatalmente a resolverse en este dilema, no menos terrible que el ser o no ser de Hamlet: o libertad de comercio, y seremos de año en año un pueblo más rico, y por tanto, un pueblo más fuerte, y en un plazo más o menos largo ascenderemos a potencia de primer orden, y volveremos a ser miembro vivo de la humanidad; o proteccionismo, y seremos cada vez un pueblo más pobre, y se acentuará cada vez más nuestra insignificancia y nuestra impotencia, y descenderemos, de caída en caída y de degradación en degradación, hasta convertirnos en la Polonia del Mediodía. (Aprobación).*

* Añadido en Estudios Jurídicos y Políticos. (N. del E.). 
¡Llamar antipatriota al pobre pueblo porque opta por sacar de su jornal la mayor cantidad posible de pan, de carbón, de telas, de luz y de ventilación en su vivienda! ¿Os tendrías por enemigos de España, vosotros, proteccionistas, porque adquirieseis máquinas y reactivos que hiciesen florecer y fructificar los centenes y los pesos duros, al punto de dar una cosecha cada semana? Pues no condenéis al pueblo porque quiere servirse de esa máquina de abaratar los productos, de multiplicar el bienestar, de fabricar oro, que se llama el librecambio. Sirviéndonos de ella, creemos ser más patriotas que vosotros, que queréis destruirla, como destruían antiguamente los obreros, víctimas de la ignorancia, las máquinas que se inventaban para redimirles del trabajo y llevarles a la conquista material del mundo. (Aprobación). Ni vosotros mismos podéis creer que con esto faltemos en nada a la dignidad ni al patriotismo, porque es imposible que hagáis consistir el patriotismo y la dignidad en vender más que en comprar, esto es, en servir más que en ser servido. En 1870 celebrábamos los españoles funciones religiosas y teatrales para socorrer a los heridos de la guerra franco-prusiana: diez años más tarde, en 1880, los franceses han hecho otro tanto para socorrer a los inundados de nuestras provincias levantinas: ¿quién será el insensato que vea en esto peligros para la dignidad ni para la independencia de Francia ni de España? Y si el ir a pedir limosna a París para los españoles o el darla en Madrid para los franceses no es pecado de cosmopolitismo ni atentado contra la integridad de la patria, ¿cómo ha de serlo el ir a vender a París, a Londres o a New York nuestras producciones con el mayor beneficio que sea posible, y comprar en Madrid, en Barcelona o en Sevilla los géneros ingleses, franceses y americanos con el máximum de baratura que se pueda? ¿Qué error tan pernicioso ese de los proteccionistas! Hacer de las aduanas medio de defensa contra el extranjero es constituirse en protector del hambre, es entregarse en cuerpo y alma al extranjero: es como si a un castillo sin 
víveres le disparasen, en vez de granadas, panes cocidos, y sus defensores los arrojaran fuera de su recinto, prefiriendo capitular por hambre con el sitiador. (Aprobación).

Sucede una cosa muy peregrina con los proteccionistas. Sus locuras de hoy me recuerdan las antiguas locuras de los patricios romanos. Cuanto más baratos nos ofrecen sus productos los extranjeros, tanto más alto pone el grito el proteccionismo. Traen los americanos trigo a 44 rs. la fanega, y al punto vocifera: «Qué horror! Nuestros labradores no pueden competir con ese precio, se van a arruinar si no acude en su ayuda el arancel" (como si fuese mandamiento de la ley de Dios o dogma de la Iglesia que nuestros labradores han de cultivar forzosamente cereales). Supongamos que llega un día en que baja más, a 20 rs., por ejemplo: “Qué escándalo! —gritarán a coro los proteccionistas-: es inútil ya cultivar trigo, porque no hay labrador a quien no salga la fanega por más de 20 rs.: vamos a tener que cruzarnos de brazos; por fuerza ha debido nacer ya el Anticristo y vive en medio de nosotros". Suponed que la cotización sigue descendiendo, que los americanos ponen el trigo en nuestras alhóndigas o almudíes a peseta la fanega, a real, que nos lo dan gratis: jadiós patria! Para los proteccionistas estamos ya perdidos, porque, como nos llenan los trojes de balde y, por consiguiente, no vamos a tener que trabajar, los infelices españoles nos vamos a morir de hambre si alguno no nos hace el favor de conquistarnos. (Risas, aplausos). Esto os parecerá ridículo, y, sin embargo, es en el fondo la lógica del proteccionismo. Nosotros importamos por valor de unos 2200 millones de reales al año, y exportamos por valor tan solo de 1800 o 2000: pues bien, esto lo tienen ellos por una desgracia y una pérdida, por una cosa abominable e insufrible; y en verdad que no se quejan sin razón: ¡Habrase visto desvergüenza mayor que la de esos extranjeros que, a cambio de 500 millones de pesetas en productos que les damos, nos envían por valor de 550! ¿Quién les ha autorizado para regalarnos esos 50 de dife- 
rencia? ¡Maniobras sin duda de la pérfida Albión, que nos engaña y explota como a indios! (Risas). Suponed que fuese posible que importáramos productos por valor de $30000 \mathrm{o}$ de 40000 millones, sin exportar por valor de un céntimo (cosa imposible y supuesto absurdo, porque el fenómeno de la importación y el de la exportación se corresponden exactamente uno a otro como el flujo y el reflujo del mar, y solo porque existe el uno se obra el otro, y no puede ascender el primero a más de lo que asciende el segundo y viceversa); suponed que se cumpliese un día ese imposible, y nadáramos en aceites, y en vinos, y en trigo, y en mármoles, y en sedas, y hubiese un cuerno de la abundancia en cada esquina y una Jauja en cada plaza: pues esto, en concepto de los proteccionistas, sería la ruina absoluta del país. (Risas). ¿Y su absoluta prosperidad? Pues, naturalmente, lo contrario; que no entrase nada del extranjero, y que lo que poseemos y vamos produciendo lo enviásemos al otro lado de las fronteras para cambiarlo por especies metálicas, hasta quedarnos sin trigo, sin vino, sin vagones, sin libros, sin máquinas, sin caballos, sin muebles, sin zapatos y sin camisa, pero con mucho oro, con mucha plata y con mucho cobre. Entonces sí que sería España libre, feliz e independiente! (Aplausos). Seamos justos. El privilegio de invención de este sistema no es de nuestros proteccionistas: corresponde en plena propiedad a los patricios romanos de la decadencia, los cuales llevaron el lujo a tan ridículo extremo que no querían gastar nada que no fuese muy costoso, hasta el punto de despreciar la luz del sol porque era gratuita, y hacer sus comidas con las ventanas cerradas para tener que encender profusión de luces en pleno mediodía. Así cierran nuestros proteccionistas las puertas de la patria y las erizan de bayonetas para que no se nos entre por ellas la riqueza, y serían capaces, si pudieran, de enviar carabineros al Sol con encargo expreso de apagarlo, a fin de explotar libres de toda competencia el negocio del gas y del alumbrado eléctrico. (Aplausos). Decía un proteccionista en 
uno de los primeros meetings celebrados por esta Asociación hace dos años que "el desenlace fatal del librecambio iba a ser tener que renunciar los españoles a todas las esferas del trabajo, y cuidarse el extranjero de importárnoslo todo trabajado"; que nosotros, al pedir el librecambio, lo que realmente pedimos es la libre entrada. Señores, he de seros ingenuo; si los extranjeros hubieran de acceder a mi deseo, confieso mi debilidad, se lo pediría así con aragonesa franqueza, y aun tengo por seguro que mis conciudadanos habían de levantarme más de una estatua por el servicio que les habría prestado. ¡Considerad si iban a desquiciarse los orbes porque los ingleses entrasen con toda libertad en España fragatas acorazadas, y locomotoras, y carbón de piedra, y tejidos de lana, y nos vistiesen gratis durante el invierno, y los franceses hicieran otro tanto durante el verano, como viste Dios gratuitamente a las avecillas del campo sin que pierdan por eso su integridad ni su independencia! (Grandes risas). Pero tengo para mí que ni los ingleses ni los franceses están de humor para divertirse en tejer lana y extraer hulla y fabricar rails por el gusto de llamarse primos de los españoles (risas), puesto que nuestros andaluces, con ser de genio más jovial, no pasan por eso de la libre entrada, manteniendo gratuitamente de vino de Jerez y de pasas de Málaga a los ingleses y a los franceses: están, sí, por la libre entrada y la libre salida juntamente, esto es, por el libre cambio, dando el vino y el aceite que les sobra a cambio de los tejidos y de las máquinas que les hacen falta.

He advertido que os reíais de los proteccionistas, juzgando acaso que son tontos en pensar así; pero debo desengañaros: no son tontos. Cuando hacen sus balances privados, se felicitan de que, durante el ejercicio de su presupuesto, haya entrado en su casa más de lo que haya salido: en esto, piensan exactamente lo mismo que nosotros y son librecambistas. Únicamente cuando se trata de las cuentas de la nación, quieren y procuran lo contrario: que 
salga más que entre. ¿Y sabéis por qué? Porque entre su interés egoísta, tal como ellos se lo fantasean, y el interés real de la nación existe incompatibilidad absoluta; porque ingresa en su casa tanto más cuanto menos ingresa en la nación. Si, como quiero bien a los proteccionistas, los quisiera mal, les desearía que, al hacer sus inventarios y cerrar sus balances, se encontraran con un saldo igual al que ellos quieren para mi patria. Y como no quiero a mi patria menos que los quiero a ellos, deseo aplicar a la nación la misma balanza que los proteccionistas aplican a sus negocios particulares. (Aprobación). Y en esto tenéis resumida la doctrina del librecambio. Querer eso es ser librecambista. Los partidarios de la protección quieren dos economías, dos aritméticas, dos criterios de juicio radicalmente opuestos e inconciliables; y yo no quiero sino un criterio solo, una sola medida, un solo rasero, una sola aritmética, una sola economía: yo quiero que desaparezca ese antagonismo artificial que han creado entre el individuo y la nación, entre la nación y la humanidad; yo quiero que exista armonía entre la economía doméstica y la economía nacional, y que no pueda enriquecerse ningún español sin que al propio tiempo se enriquezca España. (Aprobación).

Díganme ahora en conciencia quiénes son los enemigos de la prosperidad de España, si los acusadores o los acusados. Pero hay más: no se contentan todavía con eso: nos presenta el proteccionismo como reos de lesa nacionalidad, como culpables de atentado grave contra su integridad e independencia. Yo me he limitado a oponer afirmación a afirmación, ejercitando la acción de reconvención; pero ahora voy a demostrar mi tesis para distinguirme, hasta en esto, de los proteccionistas, maestros en el arte de declamar, pero que nunca prueban lo que declaman. Vosotros sabéis que hay una España oceánica, y otra España trasfretana, y otra España calpense, y otra España castellanoaragonesa, y otra España lusitana, y otra España trasatlántica, y que todas esas Españas son pedazos desunidos de una 
misma y sola nacionalidad. Pues bien: vamos a poner en claro quién se opone a la reintegración y constitución de esa patria ideal, llamada a tan altos destinos en lo futuro: si los librecambistas, como finge creer el proteccionismo, o los proteccionistas, como creo yo.

Principiemos por América. Nosotros, los españoles, seremos siempre tanto como un pueblo europeo, acaso más que un pueblo europeo, un pueblo americano. Dieciocho naciones principales se cuentan en Europa y 18 naciones en América, pero con esta diferencia, respecto de nosotros: que de las 18 naciones europeas, son españolas dos únicamente, al paso que las 18 naciones americanas todas menos dos son españolas. Y si nosotros, por nuestra posición y por nuestra historia, somos españoles americanos, los americanos son españoles europeos por su cuna, por su derecho, por sus costumbres, por su religión, por su lengua, por su temperamento y por sus aficiones. En vano han renegado de nosotros durante medio siglo; salieron de aquí tan imantados, tan llenos de nuestro espíritu, tan empapados en nuestro genio que ni el clima ni los cruzamientos ni las revoluciones han podido borrar en ellos el sello de nuestra nacionalidad, ni impedir que vuelvan fatalmente la vista hacia este centro de atracción que se llama España. En vano nos han odiado y maldecido: sus maldiciones no caían sobre nosotros ni a nosotros nos infamaban: caían sobre su propia sangre, infamaban a sus abuelos, maldecían su propia genealogía y se condenaban a sí mismos; que todavía están vivas y en pie las casas solariegas, henchidas de recuerdos, de tradiciones, de glorias y de poesía, donde tomaron cuerpo los apellidos que trasmiten a sus hijos y recibió el calor de la vida la sangre que corre por sus venas; y han servido aún para nosotros las cunas de madera en que se mecieron ellos, y nos hemos sentado al hogar en las mismas piedras en que ellos se sentaron; y suenan aún en nuestras aldeas las mismas campanas que celebraron su natalicio y que esperan celebrar con acentos de regocijo su 
regreso; y cantan los niños todavía en nuestra Península las mismas sencillas poesías que ellos cantaban, y aprenden a deletrear en la misma hermosa lengua que ellos hablan, y balbucean sus tiernas plegarias delante de las mismas imágenes a las cuales ofrecieron ellos exvotos al partir para el Nuevo Mundo, exvotos que no han cumplido jay! porque no han vuelto, pero que tendrán que cumplir un día, porque la voluntad de Dios es incontrastable, y ley de Dios es que los pueblos hermanos se agrupen en una sola familia, sin que sean parte a impedirlo tres mil leguas de océano, si bastantes para apagar el fuego de las rencillas y de los odios que nos han tenido separados durante medio siglo, impotentes para extinguir el amor que arde en nuestros corazones hacia una tierra a la cual hemos dado lo más puro de nuestra sangre y sacrificado los tres mejores siglos de nuestra historia. (Grandes aplausos). España es la casa solariega de aquel coro gigante de naciones, a las cuales está aguardando con la misma ansia con que aguardan los abuelos en el solar destartalado de Galicia al rico indiano, que emigró joven y vuelve lleno de vigor y experiencia a infundir nueva savia y prestar animación al hogar, mustio, pobre, casi apagado ya, aislado en medio de la vecindad europea, por causa de su ausencia. ¡Y qué riqueza, y qué exuberancia, y qué lozanía la del indiano que aguarda España con los brazos abiertos! La hacienda que posee es tan extensa como dos veces el continente europeo: la pueblan hoy 30 o 40 millones de habitantes: mañana, esos millones se contarán por cientos; que por esto dice, y con razón, el príncipe de los geógrafos modernos, Eliseo Réclus, que "de todas las naciones de Europa, los españoles son los únicos que pueden tener actualmente la ambición de disputar a los ingleses y a los rusos la preponderancia futura en los desenvolvimientos étnicos de la humanidad".

Ahora bien: ¿por qué se desgajaron aquellas ramas de su tronco nativo? ¿Por qué se separaron aquellos pueblos de su metrópoli y de su cuna? ¿Por dónde principiaron los des- 
prendimientos de nuestro imperio ultramarino? ¿No lo recordáis? Principiaron por Río de la Plata, por Nueva Granada, por Venezuela; y se separaron a causa de haber sido abolida, a instancias de los proteccionistas de Cádiz, la libertad mercantil, no bien habían empezado a gozar sus ventajas desde que en 1810 les había sido otorgada por la Regencia. ¿Hay medio en lo humano para reconstruir aquella unidad deshecha por errores de nuestra política? Sí; haciendo lo contrario de lo que entonces se hizo; removiendo los obstáculos que el proteccionismo interpuso en mal hora entre los españoles de América y los españoles de Europa; preparando la federación política por medio de la federación económica. ¿Por qué Bismarck ha podido fundar la unidad germánica, y Bolívar no pudo fundar la unidad americana? Porque Bismarck tuvo como predecesor y bautista a Federico List y la Liga aduanera, al paso que en Bolívar se trocaron los términos, anticipándose medio siglo al pensamiento, concebido y propagado por Torres Caicedo, de una Liga aduanera de las repúblicas sudamericanas. El proyecto está ya planteado hace dos años, y es de esperar que haga todo su camino en los 19 que todavía le quedan de vida a nuestro siglo. Después, no habrá que hacer grandes esfuerzos para que España sea admitida en ella. Se está operando un movimiento general de aproximación de la América española hacia su antigua metrópoli, y urge sobremanera que nosotros lo favorezcamos por todos los medios, literarios, diplomáticos y mercantiles. Van viniendo ya a Madrid los presidentes de aquellas repúblicas (v. g.: de Costa Rica y Venezuela). Principian a contar con nosotros como un factor esencial de su civilización, y a llamar a España su madre, como antes la llamaban su madrastra. El doctor Avellaneda, presidente que ha sido de la República Argentina, decía recientemente que "la España moderna se halla hoy en aptitud de trasmitir a los americanos, bajo todas sus fases, el pensamiento europeo", y que "españoles y americanos podemos constituir un público de 40 millones 
de almas para dar estímulos y un vasto teatro de expansión a la ciencia, al estudio y al genion. Hace poco se agitó en la prensa sudamericana la conveniencia de que aquellos Estados restablezcan sus relaciones con España, y uno de los periódicos más autorizados, La Reforma, de Bogotá, para demostrar los sentimientos que les animan para con nosotros, trascribía un párrafo de un libro escrito por uno de los fundadores de la Unión, en el que se hacen votos por que "los españoles, sus hermanos de Europa, vayan a conquistar a los americanos y a ser conquistados por ellos, con la única conquista legítima, duradera y fecunda, la conquista del amor y del bien común"; y recordaba tan nobles palabras con motivo de abogar por el establecimiento de comunicaciones directas entre España y los puertos colombianos.* Y cuenta, señores, que se trata de aquel pueblo que, hace año y medio, cuando el Presidente de los Estados Unidos tuvo la torpe audacia, renovada estos días por Mr. Blaine, de invocar la decantada doctrina de Monroe a propósito del canal interoceánico de Panamá, contestó con noble altivez, por sus órganos en la prensa, que Colombia no necesitaba ni toleraría el protectorado de los Estados Unidos ni el protectorado de Francia. Motivo este de enhorabuena para nosotros, que podemos hacernos cuenta de que aquella gran vía comercial habrá de abrirse en tierra española, y que españolas serán sus dos riberas, como en su día también las dos orillas de Gibraltar. Creen ligeramente algunos que nuestra misión en América ha concluido, y yo pienso, por el contrario, que ahora es cuando verdaderamente principia. Aquel vapor español, Blasco de Garay, que hace pocos meses conducía a Méjico los des-

* Nota añadida en Estudios Jurídicos y Políticos: "Desde que se pronunció este discurso, el movimiento de aproximación de la América Latina a España se ha ido acentuando en progresión rápida. Vid. como ejemplo los hechos que cita el Boletín de la Institución Libre de Enseñanza, Madrid, en el artículo "España en América", núm. 137 (30 de octubre de 1882)". (N. del E.). 
pojos mortales de uno de sus presidentes, y aquel Ayuntamiento de Méjico que declaraba hijo adoptivo de su municipio al general español que lo acompañaba, son el noble símbolo del nuevo período que ahora se abre en nuestra historia. Vamos a reconquistar la América; pero a condición de que a esa reconquista destinemos ejércitos de mercaderes y de cónsules, de libreros y de profesores. Para romper el hielo que todavía mantiene divorciadas la España peninsular y la España ultramarina, debemos apelar en primer término a ese poderoso fundente que se llama el comercio. Mi ideal en este respecto se reduce a bien poco: declarar interior todo nuestro comercio con las naciones hispanoamericanas: con esto solo se habría suprimido más de la mitad de la distancia moral que nos separa de ellas. Y mientras ese ideal se logra, celebrar con todas tratados de comercio lo más expansivos y liberales que sea posible. ¡Cuánto más habría prosperado la industria catalana si, en vez de prodigar tesoros de actividad y reñir batallas de diplomacia florentina contra el librecambio en los pasillos del Congreso y en las antesalas de los ministerios, se hubiesen abierto de par en par los fabricantes aquel mercado de 40 millones de habitantes que tan buen juego hace a los ingleses y a los alemanes! Muy urgente es, como os decía en el anterior meeting, celebrar un tratado de comercio con Inglaterra; pero estoy por decir que urge más todavía celebrarlos con aquellas naciones sud-americanas, donde se ofrecen horizontes vastísimos a nuestra agricultura y a nuestra industria, a los tejidos de Cataluña, a las frutas secas de Valencia y de Andalucía, a los vinos aragoneses y manchegos, a los azúcares antillanos, a los tabacos filipinos, a la marina mercante antillana y peninsular, y que, además del interés mercantil, envuelven otro interés mayor, el interés político.

Ahora, decidme, proteccionistas, ya que tanto blasonáis de patriotismo, ¿cuál ha sido vuestra política de atracción con respecto a América? ¡Ah!, dígalo Venezuela. El comercio de vinos con aquella República había cobrado un desarro- 
llo prodigioso: en Andalucía, en Cataluña y en Alicante se habían establecido casas de comercio dedicadas exclusivamente a la exportación de vinos a Venezuela: habían creado clases especiales adaptadas al gusto de aquel país: sus marcas estaban ya acreditadas en aquellos remotos climas: los armadores habían construido buques especiales con quilla plana para navegar en aquellas playas. El proteccionismo sintió algo así como remordimiento por tolerar tanta prosperidad, y tendió sus negras alas sobre los dos países, y provocó la guerra de represalias, y paralizó el comercio, quebrantando no pocas fortunas e irrogando perjuicios irreparables a la agricultura y a la industria naviera. España había establecido indirectamente tarifas diferenciales a la entrada del cacao de Caracas respecto del de Guayaquil, y el Gobierno de Venezuela impuso un recargo de 1000 por 100 al vino español con respecto al vino de Burdeos: de un duro por arroba, subió repentinamente a 10 duros. Pero no bastaba esto todavía. El Presidente de la República vino a Madrid con el propósito de negociar un tratado de comercio beneficioso para los dos países. Todos recordamos con pena cómo recibió el Jefe del Gobierno español, jefe oficial también del proteccionismo, al noble hijo de América que venía a ofrecer a su vieja madre la fecunda alianza del trabajo: jamás la política de repulsión y de aislamiento, propia de todo sistema conservador y proteccionista, tuvo explosión más ruda: desairado, herido en su dignidad de hombre y en su amor propio de Jefe de un Estado, no bien llegó a Venezuela, declaró libres de todo derecho los vinos franceses, y poco después cerró herméticamente a los nuestros las puertas y mercados de la República por el medio indirecto de imponerles un derecho de 1000 rs. por arroba. ¡Batid palmas, proteccionistas! ¡Ilustres patriotas, estos son los triunfos de vuestra política en América! Habéis tenido la rara habilidad de causar de un solo golpe dos heridas a esta patria a quien idolatráis tanto: una, en concepto de productora de vino; otra, en concepto de consumidora de cacao. Algunas 
veces me pregunto yo aterrado: si, queriéndola con tan entrañable amor como ellos dicen, la tratan tan despiadadamente, ¿qué sería de ella si llegaran a aborrecerla? ¿No es verdad, señores, que tiene motivo España para suplicar a esos hijos predilectos que no la quieran tanto, porque sus caricias y sus abrazos se parecen al abrazo del oso? (Aplausos).*

Mirad, ahora, si no tenían razón los vinicultores en ser librecambistas. Es verdad que se me ha objetado: y los fabricantes de chocolate, ¿cómo se explica que los haya proteccionistas? Eso consiste, replico yo, en que algunos de ellos han conseguido emancipar su industria de la tiranía del azúcar y del cacao ultramarinos, y fabrican su producto con cacao extremeño (risas), chocolate indígena (grandes risas), español de pura sangre, o mejor dicho, de pura bellota (risas y aplausos); y señores, habéis hecho bien en aplaudirles, si no por la acción, al menos por la lógica, pues siendo, como son, proteccionistas, proceden de acuerdo con su sistema, protegiendo por ese medio tan ingenioso el cultivo de la encina y fomentando de paso la repoblación de nuestros asolados montes. (Risas y aplausos). A este propósito, recuerdo que en el meeting celebrado en Gerona en junio último decía un abogado de aquella ciudad que el librecambio solo se comprende en los tiempos primitivos, en que el hombre se alimentaba con productos naturales, pero no hoy en que el arte humano pone en los objetos de consumo tanto o más que la naturaleza; y coronaba esta explicación, no menos primitiva que los tiempos a que hacía referencia, dirigiéndonos, en medio de atronadores aplausos, el siguiente apostrofe, de un realismo encantador: "Librecambistas, si queréis plantear vuestro sistema, contentaos comiendo bellotas!". (Grandes risas). Vea el fogoso orador gerundense cómo sus correligionarios, los fabricantes de chocolate proteccionista, no han querido aguardar a que

* "(Aplausos)": añadido en Estudios Jurídicos y Políticos. (N. del E.). 
se plantease el librecambio para volvernos a aquellos felices y dorados siglos cuyas excelencias cantaba D. Quijote delante de los cabreros, contemplando extasiado un puñado de bellotas; y abrigo la convicción de que, si el proteccionismo pudiera realizar sus sueños, retrocederíamos, no digo al siglo i de Jesucristo, en que, según testimonio de Plinio y de Estrabón, los españoles se sustentaban con bellotas durante nueve meses del año, sino al siglo de oro de D. Quijote, en que no se conocía otro alimento que ese, y por añadidura, andaríamos en cuatro pies. (Risas y aplausos). Yo no le veo otra salida que esa al proteccionismo. Digamos en honor suyo que no tardó el proteccionismo en comprender el mal paso en que se había empeñado, y ha querido congraciarse con la vinicultura dirigiendo dos peticiones al Gobierno en enero y en julio del año pasado, e interesando en ellas la pronta terminación del tratado de comercio con Venezuela. De hombres es errar, de ángeles arrepentirse: bienvenidos sean a nuestro campo esos proteccionistas de ocasión, mientras yo dejo a América y me vengo a Portugal.

$\mathrm{Si}$, como antes os he dicho, deseo la unión aduanera con la América española, si yo aspiro a que se declare comercio interior todo el que aquellas repúblicas hacen con nosotros, qué os diré de Portugal, no ya nación filial como ellas, sino pedazo de la metrópoli, que la ambición de los reyes feudales en el siglo xI, y el despotismo de los reyes absolutos en el siglo xvII, y la torpeza de los reyes constitucionales en el siglo XIX, empujaron en malhora a una emancipación que debía tener como natural salida la servidumbre y la vergüenza de un protectorado? Parece España un Cristo que va descendiendo lentamente de su cruz, donde la pusieron pecados y torpezas de nuestros gobernantes, y a la cual la sujetan dos clavos todavía, la mano izquierda en Gibraltar, los pies en Lisboa. No son, no, los portugueses extranjeros para nosotros: Portugal es nuestra patria con igual derecho que Aragón, que Cataluña 
o que Andalucía: cuando hace poco tiempo la opinión irritada de nuestros vecinos obligó al Gobierno de Lisboa a dejar sin efecto el tratado relativo a Lourenço Marques, sentí la misma alegría que cuando se pactó la paz del Zanjón, porque veía salvado aquel rico territorio que Inglaterra había logrado arrancar por sorpresa a Portugal y que yo consideraba como colonia de mi patria. ¡Si estoy por decir que los portugueses, a pesar de ellos mismos y de todas sus alharacas y protestas, son más españoles que los vascongados, más aún que los catalanes, y que, si ha de haber aduanas entre España y Portugal, la lógica las pide entre Castilla y Vizcaya, entre Aragón y Cataluña! (Aplausos). La historia de Portugal es nuestra misma historia: su raza es nuestra misma raza: son gallegos, extremeños, leoneses; su lengua es nuestra misma lengua; el catalán y el portugués son el Oriente y el Occidente de nuestra filología lingüística, influida de griegos y de suevos; sus glorias son nuestras glorias: Alburquerque y Camoens son tan nuestros como son suyos Hernán Cortés y Cervantes: somos hijos de un mismo pasado, vivimos de un mismo espíritu, caminamos a un mismo ideal. En la fortuna como en la desgracia, caminaron siempre juntas las dos naciones: corrieron en común más de la mitad de su existencia, hasta el siglo XI. Con su Viriato peleamos contra Roma, y con nuestro Pelayo combatieron contra el islam: la sangre de los castellanos corrió a las puertas de Viseo, y la sangre de los portugueses a las puertas de Tarifa: al compás de nuestros municipios desarrollaron los suyos y atajaron los vuelos del feudalismo: su gran legislador Dionis se formó en la escuela de nuestro Alfonso el Sabio: con ellos fuimos a dominar en Asia, y con nosotros vinieron a colonizar en América: juntos en una misma nave, el español Elcano y el portugués Magallanes dieron por vez primera la vuelta al mundo, partiendo por Ocaso y volviendo por Oriente, bellísimo símbolo de los destinos que nos tiene reservados el porvenir para el día que otra vez se junten esas dos mitades de nuestra nacio- 
nalidad: les vencimos en Toro y en Alcántara, y nos vencieron en Aljubarrota y en Villaviciosa: juntos caímos bajo el yugo de los Felipes: juntos abrimos de par en par las puertas de la Península a los vientos del espíritu moderno, ellos con Pombal, nosotros con Aranda; juntos defendimos la independencia de la Península en los llanos de Bailén y en los desfiladeros de Torres Vedras, y sus huesos se mezclaron con nuestros huesos en Arapiles, como en otro tiempo en el Salado: juntos alzamos el pendón de la libertad en 18-20, y unánimes proclamamos la Constitución del año 12 en Lisboa y en San Fernando, y a un mismo tiempo nos declaró la guerra el absolutismo, y lo vencimos, ellos en don Miguel, nosotros en don Carlos; hasta que, persistiendo en su ciego amor a la autonomía, siquiera nominal e imaginaria, y conculcando con satánico orgullo esa ley de Dios que quiere que seamos una sola familia, y que nos cobijemos bajo una misma bandera, han venido a ser, en justo castigo, el Canadá de Europa, una provincia autónoma de Inglaterra, y se diría que Jesús había querido anunciarles este desenlace con la parábola del hijo pródigo, que, por huir la dulce tiranía del hogar paterno, cayó bajo la dura servidumbre de un porquero. (Grandes aplausos).

Por fortuna, el tratado con Inglaterra acerca de la bahía de Lourenço Marques les ha hecho abrir los ojos, y han principiado a comparar la nobleza y el desinterés de España con la codicia y el egoísmo de Inglaterra. Hace pocos meses, un diario importante de Oporto decía que la nación británica es siempre la terrible ave agorera de los destinos lusitanos, que se acerca a las naciones para hacer presa en ellas cuando una enfermedad grave las aflige. La docta y sesuda Sociedad de Geografía de Lisboa escribía en un informe reciente, aludiendo a Inglaterra, que la solución del problema colonial obliga a la nación portuguesa a adoptar una actitud defensiva, en vista de los acontecimientos que ha presenciado recientemente y de las tendencias de absorción que por parte de los extranjeros se han manifesta- 
do con respecto a su territorio. Sus revistas dramáticas no provocan ya el odio solamente contra nuestro país: envuelven en la misma condenación al Reino Unido. Así, señores, los portugueses, cansados y desengañados de Inglaterra, no tardarán en volver los ojos a España, y a pesar los inconvenientes del protectorado inglés y las ventajas de la unión ibérica. No abogan por ella tan solo partidarios del régimen republicano: hay ya hasta monárquicos que entrevén solución por aquí a los más graves problemas de la política lusitana. Hace pocos meses, un publicista portugués, el Dr. Barbosa Leão, abogaba públicamente en un folleto por la unión de España y Portugal bajo una cualquiera de las dos dinastías de Borbón o de Braganza, y casualmente anteayer ha vuelto a insistir en su doctrina en O Commercio de Portugal, entendiendo que semejante confederación haría de nuestra Península una de las primeras naciones del globo, y que de ella sacarían los portugueses, entre otras ventajas, la de asegurar sus posesiones ultramarinas contra la ambición y la codicia de Inglaterra.

Ahora bien; ¿saben los señores proteccionistas, acaparadores de patriotismo con privilegio exclusivo, cuál es el primer paso para esa confederación política, según los iberistas de Portugal y según los librecambistas españoles? Pues es la unión económica de los dos países, con liga aduanera, unidad de legislación fiscal, comercial y marítima, representación consular común, libertad de navegación fluvial, y supresión de todas las aduanas en la raya. Con efecto, el obstáculo más poderoso entre cuantos se oponen a la unidad ibérica es el proteccionismo. Así como, para soldar los dos extremos de una plancha de metal, principia el estañador por limpiar de toda suciedad muy cuidadosamente la juntura, para soldar a Portugal y España, hay que principiar por limpiar la frontera imaginaria que los divide, de esos cuerpos extraños que se llaman aduanas y carabineros. (Aplausos). Poner aduanas entre España y Francia, entre España e Inglaterra, es un error económico que cuesta la 
vida a muchos españoles; pero poner aduanas entre España y Portugal, es más que eso, es un error político que cuesta la vida a España misma. Porque mientras no sea un hecho la unidad ibérica, ni Portugal saldrá de su insignificancia, ni España saldrá de su postración, ni se redimirá de su caída, ni realizará ninguno de esos grandes ideales que le imponen su situación en el planeta y su pasado en la historia. ¡Es mucho patriotismo ese de los proteccionistas que consiste en obligar a los portugueses a entrar de contrabando, o facturados como género francés, los tejidos de algodón de Cataluña, y en buques ingleses el azúcar de Andalucía! Después de todo, yo no comprendo su ilogismo, al verles contribuir con sus capitales a la apertura de líneas férreas entre Portugal y España. Destruir aduanas equivale a construir ferrocarriles, porque tanto lo uno como lo otro da por resultado estrechar las distancias que separan a los pueblos. Dentro de poco, se contarán nada menos que seis líneas para acercar los portugueses a los españoles y multiplicar sus relaciones mercantiles: pues bien, fundar el Zollverein ibérico, retirar los carabineros de la raya de Portugal, equivale a construir otros seis ferrocarriles gratuitos que borrarán distancias y abrirán nuevos mercados a nuestros tejidos, cuya fabricación es casi desconocida en Portugal, así como también a nuestras harinas, arroces, lanas, ganados, aceites, aguardientes, azúcares y cafés, a cambio de lo cual nos darán los portugueses los ricos productos de sus vastísimas colonias.

Tan claras son estas verdades que se imponen aun a los mismos interesados en oscurecerlas o en negarlas. Los ingleses, que naturalmente han de desear que siga imperando la política de aislamiento y de divorcio que seguimos con Portugal, nos decían hace tres meses, por órgano del Times, a propósito de la entrevista de Cáceres, cuán grandes ventajas nos reportaría la reducción de tarifas en las aduanas de Portugal mientras no se realice la unidad ibérica. Pero ¿qué digo el Times? El mismo D. Luis de Portugal, que, apesar de ser 
rey, se ocupa alguna vez de cosas útiles al pueblo (aplausos), dijo en Cáceres, en aquella misma ocasión, que encuentra grande la idea de una federación entre los dos países, pero peligrosa, porque daría fuerza al federalismo cantonal, y abriga el propósito de estrechar las relaciones mercantiles entre los dos países. Sin entrar a discutir el grado de sinceridad que haya en los temores expuestos, ya me daría yo por muy contento con que se mejorasen y armonizasen los intereses mercantiles de los dos países, y más aún si, como anunciaron los periódicos franceses, esa unión toma la forma de una liga aduanera semejante a la alemana. La unidad económica lleva en germen y trae fatalmente en pos de sí la unidad política. Dadme una liga aduanera, y antes de medio siglo os devolveré una confederación política: cuarenta años han bastado para pasar de Federico List hasta Bismarck, para convertir el Zollverein en un imperio germánico. Hagámonos la cuenta de que la unión ibérica es como un haz de uniones parciales, la unión aduanera, la unión marítima y consular, la unión postal y monetaria, la unión literaria y profesional, la unión colonial, la alianza defensiva, la alianza ofensiva, etc.; procurémoslas una tras otra, y así, lentamente, por asimilaciones parciales, y contando con la virtud creadora del tiempo, volveremos a la vida esa España de nuestros ensueños que por la fuerza no lograríamos jamás, a la manera como cede al débil esfuerzo de un niño, que las va quebrando una a una, el haz de flechas que había resistido los robustos esfuerzos de un atleta.

Siento no poder examinar esta tarde, con el mismo sentido, el problema de África y el de Gibraltar. Lo avanzado de la hora me obliga a concluir en este punto. He principiado a bosquejar delante de vosotros, a reserva de continuar en otra ocasión, el ideal exterior de nuestra patria, en sus relaciones con el problema arancelario. Urge sobremanera que pongamos manos a la obra, si hemos de desmentir una vez siquiera la tradición puramente española de llegar tarde a todas partes. Que los Gobiernos acometan con decisión y 
con brío la reforma, sin hacer caso del clamoreo que levanten los egoísmos individuales: tenga en cuenta que los primeros interesados en que el librecambio se plantee son los que más duramente lo combaten. A los pueblos cancerados por la lepra del proteccionismo, nácenles contrabandistas y matuteros, como a los cuerpos cubiertos de úlceras les nacen gusanos; pero de igual modo que hay que educar al pueblo, aunque el pueblo rechace la instrucción y los Ayuntamientos persigan al maestro; de igual modo que hay que establecer en España las libertades que España puede sobrellevar, a pesar de ella misma, con o contra el pueblo, con o contra las Cortes, hay que implantar resueltamente el librecambio, a pesar de los industriales que lo rechazan, como se lava y se limpia al infantuelo rebelde aunque llore y se desgañite, porque, si, obedeciendo su inconsciente sufragio, se desterrase el régimen del agua y de la esponja, no tardaría en convertirse en una repugnante gusanera. (Aplausos). Yo deseo que caminemos despacio, pero que caminemos, sin detenernos nunca ni retroceder. Nuestros políticos están acostumbrados a cabalgar en hipogrifos alados y en pegasos, pretendiendo salvar los espacios en minutos: yo preferiría que montaron modestamente en el asno de Sancho Panza; tardarían en llegar, pero llegarían de seguro y no se estrellarían nunca. Por el sistema imperante, parece que corremos mucho, y en realidad no hacemos sino dar vueltas vertiginosas alrededor del punto de parti$\mathrm{da}$, haciendo lo que Dios mismo no puede hacer, destruir tiempo, borrar años, con la misma facilidad que si fuesen guarismos escritos con yeso en el gran encerado de la historia. En tiempo de la primera restauración, aquel monstruo repugnante que se llamó Fernando siete borró de una plumada los seis mal llamados años que habían trascurrido desde 1808 hasta 1814; y los doceañistas, por no ser menos, suprimieron los seis años siguientes desde 1814 hasta 1820. En tiempo de la segunda restauración, el Ministerio Cánovas borró de una plumada los seis sin duda también 
llamados años* que habían corrido para la reforma arancelaria desde 1869 a 1875; y el Ministerio Sagasta, por no ser menos, se apresta a suprimir también para la misma desdichada reforma los seis años trascurridos desde 1875 a 1881. ¡Cuando lo que necesitamos es, al revés, condensar el tiempo, fabricar años, haciendo de los minutos horas y de los días meses:** Con este eterno destejer de la Historia, dejando que así se enmohezcan los resortes de la vida nacional, sin conciencia del tiempo y de la vida, que es acción y movimiento, ¿cómo ha de llegar a constituirse la nacionalidad española, ni a realizar ninguno de esos grandes ideales, sin los cuales España no tendría razón de ser en el universo, y habría de disolverse como se disuelve todo organismo agotado y que falta a la ley de su destino?

Voy a recordaros, a este propósito, y con ella hago punto, una lección que nos ha trasmitido el siglo xiII. Brota del seno de una batalla, y, sin embargo, es una lección de política internacional y de economía política: por eso tiene cabida en este meeting.***

Una de las joyas más preciosas de nuestra literatura es, sin disputa, el Poema de "Fernán González"; y uno de los episodios más hermosos de ese poema, la batalla del Ebro o de Era Degollada. Fernán González, conde de Castilla, sale al encuentro de don Sancho de Navarra, que había entrado en sus tierras robando los pueblos y yermando los campos, y le da batalla, y lo derrota, y lo mata; pero no sin antes haber recibido él mismo tantas y tan crueles heridas, que por muerto hubieron de recogerle los suyos del campo de batalla. En auxilio del navarro acudían y llegaron aque-

* En el folleto original publicado por la Asociación para la Reforma Liberal de los Aranceles de Aduanas figuraba "mal llamados años". (N. del E.).

** En el folleto original publicado por la Asociación para la Reforma Liberal de los Aranceles de Aduanas había punto y aparte. (N. del E.).

*** En el folleto original publicado por la Asociación para la Reforma Liberal de los Aranceles de Aduanas había punto y seguido. ( $N$. del E.). 
lla noche los condes del Poitou y de Tolosa, con sendos ejércitos. No bien rayaba el alba, el conde castellano, vuelto ya en sí, y bañado en la sangre que manaba de sus heridas, salta del duro lecho y ordena sus huestes. Los infanzones que regían las mesnadas, cansados de tanto pelear, pugnan por disuadirle de dar nueva batalla contra dos ejércitos de refuerzo, y le aconsejan una tregua de diez días siquiera, a fin de dar lugar a que lleguen los refuerzos que se esperaban de Castilla, y a que se cierren con el sosiego las heridas que ponían en grave riesgo su vida y la suerte del condado. Entonces, Fernán González, con la frente centelleante, personificación ideal de nuestra patria, les dice con voz solemne:

Un día que perdamos, nunca lo podremos cobrar, Jamás en aquel día non podremos tornar...

Non cuentan de Alexandro los annos nin los días; Cuentan sus buenos fechos e sus caballerías... Es menester, por tanto, que los días contemos, Los días y las noches en que las expendemos. Cuantos días en balde pasan, nunca los cobraremos. Amigos, bien lo vedes, que mal seso fazemos."

Y dicho esto, mueve las huestes, atraviesa el Ebro a nado, rompe los escuadrones enemigos, puebla las riberas de cadáveres tolosanos y gascones, prende trescientos caballeros, da muerte al conde de Tolosa, y regresa victorioso a sus estados. De esta manera, señores (y ténganlo entendido así nuestros Parlamentos, que hacen de cada legislatura un discurso sin fin; ni lo olviden nuestros ministerios, que cifran toda su gloria en perpetuarse en el banco azul; y sabedlo vosotros, proteccionistas maquiavélicos, que reclamáis eternos aplazamientos a la reforma arancelaria, a pre-

* En el folleto original publicado por la Asociación para la Reforma Liberal de los Aranceles de Aduanas la cita no está compuesta como un poema. (N. del E.). 
texto de que estamos heridos, y vosotros también, librecambistas inocentes, y no aludo a todos, que os dejáis prender en el lazo y consentís en volver a 1875, o, tal vez, a 1869), de esta manera, repito, contando su vida por sus hechos, y no por sus años, no perdiendo un solo día, Fernán González fundó a Castilla: de esta manera también, pagándonos de la acción más que del pensamiento y del pensamiento más que de la palabra, no perdiendo un solo día ni dejando nada para mañana, fundaremos nosotros a España. "E si non, non”. (Grandes y prolongados aplausos). 

Discurso pronunciado en el meeting de la Asociación para la Reforma Liberal de los Aranceles de Aduanas sobre el tema

\author{
"URGENCIA DEL LEVANTAMIENTO \\ DE LA SUSPENSIÓN DE LA BASE 5. \\ DE LA LEY ARANCELARIA: \\ NECESIDAD DE DECRETAR \\ LA LIBRE IMPORTACIÓN DE CEREALES»
}

Celebrado en el Teatro de la Comedia de Madrid el día 21 de mayo de 1882 



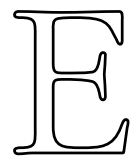
L SR. COSTA: Señoras y señores: Van ya tres veces que se ha intentado en España reducir los derechos arancelarios protectores a derechos fiscales, y otras tantas veces que el proteccionismo logra burlar las esperanzas del país, cada vez más afecto a las doctrinas, y, si no a las doctrinas, a las prácticas del librecambio: la primera, en el período de 1840 a 1843 , en que los fabricantes se contentaban con un plazo de 15 años para liquidar sus industrias, o para trasformarlas, o disponerlas a resistir la competencia del exterior: la segunda, en 1869, en que esos mismos fabricantes juzgaron suficiente un plazo de 12 años para igual objeto, con reducciones escalonadas, que hubiesen concluido el verano pasado; la tercera, en estos mismos instantes, por virtud del proyecto presentado a las Cortes por el Sr. Camacho, e informado anoche por la Comisión respectiva del Congreso que preside un ilustre miembro de esta Asociación. Suele decirse que a la tercera va la vencida: ¿se cumplirá en el presente caso ese refrán vulgar? ¿Se planteará por fin la base 5.? El Jefe del Gobierno, en su discurso de hace 12 días, ha contestado rotundamente que no: hablando, más que como convencido, como resignado, decía que el tratado franco-español se le ha impuesto como una necesidad, por virtud del compromiso contraído por los conservadores en el convenio de 1877; pero añadía, para consuelo de fabricantes, que, en cambio, ese tratado ha imposibilitado el restablecimiento de la base $5 .^{\mathrm{a}}$, que ha limado los dientes y cortado las uñas a ese 
monstruo feroz que amenazaba constantemente devorar la industria española. ¡Monstruo feroz la base 5." No habían dicho tanto los más rabiosos partidarios de la protección. Es triste sino el sino de la política española. Comparad ese lenguaje del Sr. Sagasta, proteccionista de ocasión en este instante, con el lenguaje del Sr. Sagasta librecambista convencido hace pocos años, cuando era miembro de esta Asociación, y tendréis la expresión fiel y viva de lo que son por regla general los estadistas españoles. En otros países, los hombres de Estado son poder hasta los 70 o los 80 años, y, sin embargo, nunca retroceden: llevan a la vida pública el caudal de experiencias* que han atesorado en tan larga práctica de los negocios, y, si alguna vez mudan, es en el sentido de la opinión o de las necesidades de los tiempos, es decir,** hacia adelante, nunca hacia atrás, sino por rara excepción. En España, por el contrario, los estadistas envejecen pronto: alrededor de los 60 años se arrinconan o los arrinconan: su vida pública no excede casi nunca de 30 años, y, sin embargo, no saben imprimir unidad y consecuencia a sus actos en tan breve período, ni aprovechar, no digo ya la experiencia de sus antecesores, pero ni la propia experiencia: pasan la primera mitad de su vida haciendo propósitos de reformas y fabricando un programa para batir con él el alcázar del poder, y la otra mitad arrepintiéndose de él y dando la razón a sus adversarios, quemando los ídolos que antes habían adorado, y contribuyendo a que la política española sea una verdadera tela de Penélope, y a que el pueblo español viva en una eterna infancia, sin ley, sin gobierno, sin ideales, hambriento de pan y de cultura, y orillado a un lado en la corriente del progreso como una escoria de la civilización (Aplausos).*** Menos mal cuando, después de haberse perdido todo, queda todavía el (N. del E.).

* "de experiencias": añadido a mano en el ejemplar del AHPH.

** "es decir,": añadido a mano en el ejemplar del AHPH. (N. del E.).

***: "(Aplausos)": añadido a mano en el ejemplar del AHPH. ( N. del E.). 
pudor, que envuelve una esperanza de redención para lo venidero. Pero el Sr. Sagasta, que reconoce que «el partido liberal hubiese cumplido con su deber restableciendo la base $5 .^{a}$, dice que, sin embargo, no solo no la ha restablecido, sino que no la restablecerá; es decir, declara que no solo ha faltado a su deber, sino que se propone seguir faltando a él. ¿Qué puede esperarse de un partido que oye en calma y tolera semejantes atrocidades? ¡Ah, Sr. Presidente del Gobierno! Cuando a tal punto se pierde la brújula y se arruina la fe, y se encallece la conciencia, y se anubla el entendimiento, y se apaga la energía, y el miedo invade las potencias, y la vejez penetra sigilosamente en el alma antes de tiempo, todavía el varón fuerte debe conservar la suficiente serenidad para no emular al perro del hortelano, y retirarse a tiempo, dejando el paso franco y libre a las nuevas generaciones que vienen con la frescura y el ardor juvenil tan necesarios para reñir las duras batallas de la vida en este siglo por excelencia batallador (Aplausos).* El banco azul no es una poltrona, sino un palenque: al Gobierno no se va** a dormir, sino a gobernar: el que no sepa o no quiera, que lo deje. Y puedo decir esto con tanto más motivo, cuanto que el mismo Sr. Sagasta se ha puesto espontáneamente en el buen camino: "si yo supiera (decía en el discurso antes citado) que el tratado de comercio con Francia había de traer las consecuencias que se anuncian, arruinar algunas industrias, sumir en la miseria y lanzar a la mendicidad a infinidad de obreros, antes que consentirlo, me habría retirado del Gobierno, y si me hubiese visto obligado a firmar ese proyecto, antes que firmarlo, me habría cortado la mano". Pues bien, Sr. Sagasta: antes de firmar la suspensión de la base $5 .^{a}$, cortaos la mano, o si no, no: no os

* "(Aplausos)": añadido a mano en el ejemplar del AHPH. (N. del E.).

** "no se va": El orden de las palabras se alteró en el ejemplar conservado en el AHPH. En el folleto publicado por la Asociación para la Reforma Liberal de los Aranceles de Aduanas se decía "se va no". (N. del E.). 
cortéis la mano, pero salid del Gobierno, porque la suspensión de la base $5 .^{a}$, tanto como la sequía, acaso más que la sequía, ha sido causa de que millares de infelices braceros del campo se arrastren a las puertas de los extenuados propietarios implorando una limosna, o emigren a Argelia o a Buenos Aires, hallando más llevaderos los ultrajes de BuAmema y la fiebre amarilla de las Pampas que el fomento del trabajo nacional por el proteccionismo y las inclemencias del cielo de su patria. (Aplausos).

$\mathrm{Y}$ aquí tenéis el objeto del presente meeting, que promete ser una solemnidad excepcional, por la calidad excepcional también de los oradores que en él han de tomar parte, especie de banquete de la elocuencia, para disponeros al cual estoy encargado de detallaros la carta y de serviros el ajenjo por vía de aperitivo, mientras van llegando todos los convidados. Ante todo, voy a presentaros el personal que ha de funcionar esta tarde: un orador que ha consumido gran parte de su vida en penetrar la esencia de las leyes económicas; otro orador cuya palabra de cristal reviste de un cuerpo diáfano las ideas más abstrusas: otro economista, en cuya boca se dan cita el análisis germánico y el humorismo inglés, y cuya elocuencia nerviosa y acerada diríase salida de las fraguas del fabricante Krupp; otro estadista, que alinea cifras en sus discursos, como Moltke alinea soldados en los campos de batalla, para lanzarlas, no a la carrera, sino sosegadamente y a paso de revista, y desbaratar con ellas los castillos fantásticos que levanta el proteccionismo; otro economista, cuyos discursos son poemas didácticos, que pone la poesía al servicio de la ciencia, y presta a la ciencia los colores de la poesía, borrando las fronteras que separan el conocimiento de la belleza; otro polemista infatigable, cuya elocuencia recuerda el ariete de los legionarios romanos, que contunde, magulla, aplasta a su adversario, y que cuando lo tiene ya postrado a sus pies, lo remata blandiendo en el aire una carcajada, como el paladín antiguo el puñal de misericordia. Y ahora que ya 
conocéis por el perfil a los oradores, voy a deciros el programa: la gravísima cuestión de subsistencias, el hambre de Andalucía, la emigración de Levante, el grado en que pueden contribuir a remediar este azote, que no es azote de Dios, sino azote del proteccionismo, las tarifas aduaneras; la no menos grave cuestión de las primeras materias; qué son primeras materias, hasta qué punto es justo y conveniente declarar libre y exenta de derechos su introducción en España, y qué compensación deben recibir en cambio los que las producen; influjo que está llamada a ejercer en el desarrollo de las industrias fabriles y manufactureras de nuestra patria la reducción gradual y paulatina de los derechos de los aranceles de aduanas vigentes en España, en la forma que lo establece la tan traída y llevada base 5. ${ }^{a}$; efectos que el planteamiento de esta base ha de causar en la riqueza del país, en el desenvolvimiento de la producción agrícola, aumento de bienestar en las clases proletarias y decrecimiento de la emigración; y por último, influjo de esa misma medida con respecto a las rentas del Estado, mejora del crédito nacional, desarrollo de las obras públicas, etc.: tal es el programa de cuestiones que la Asociación para la Reforma Liberal de los Aranceles de Aduanas ha trazado a sus oradores para esta tarde. Yo voy a delinear una breve perspectiva de todas ellas, a fin de que sirva como de introducción al meeting.

Mi amigo el Sr. Pedregal se ocupará de cereales, naturalmente, desde el punto de vista de la libertad de comercio. Permitidme que rompa yo la marcha con ellos, siquiera porque son la mercancía más liberal que yo conozco. Ellos, los cereales, han constituido siempre el argumento más elocuente y más sólido que se haya formulado jamás en favor del librecambio; tan elocuente que, al oírlo, o mejor dicho, al sentirlo, los más convencidos partidarios de la protección han depuesto las armas y se han declarado temporalmente librecambistas. Siempre que el país se ha visto afligido por alguna grave crisis alimenticia, en 1847, en 
1856, en 1868, la primera medida, acaso la única medida que ha discurrido la opinión y que ha adoptado el Gobierno, ha sido declarar de libre introducción los cereales extranjeros; y es, señores, que el hambre es un género esencialmente proteccionista, y naturalmente, para matarla, había que recurrir a procedimientos de librecambio (Aplausos).* Ya veréis cuan admirablemente desarrolla esta tesis el señor Pedregal, con aplicación inmediata a la crisis horrible que vienen atravesando en la actualidad multitud de provincias españolas. Yo me permito, sin embargo, someter a su consideración otro aspecto del problema que cae de lleno, aunque a primera vista parece que no, dentro de la jurisdicción de este meeting. No basta que se abarate el pan para que los jornaleros del campo puedan comerlo: es necesario, además, que tengan dinero con que puedan comprarlo. Para que se abarate, basta una medida librecambista, la exención de derechos; mas, para que puedan comprarlo, una vez barato, hace falta una medida proteccionista; y no se alarme el señor Presidente, pues entiendo referirme a aquel género de protección que es una forma y una manifestación de la justicia, a aquel género de protección que aprovecha juntamente y por igual a productores y a consumidores, a labradores y fabricantes; hace falta, digo, plantear un vasto sistema de obras públicas, pero de obras públicas que no causen efectos transitorios, que no sean hijas de la inspiración del momento, ni se reduzcan a una mezquina trasferencia de 14 o 16 millones, sino que respondan a las necesidades permanentes del país y sean tan amplias como ellas. Me explicaré. La crisis actual reconoce por madre natural a la sequía, que ha destruido la cosecha de cereales, y por padre legítimo al sistema protector, que no ha permitido sustituir este cultivo por otro menos expuesto a esa calamidad. Pues bien; ¿hay que combatir la sequía? Las obras públicas habrán de ser canales de riego.

* "(Aplausos)": añadido a mano en el ejemplar del AHPH. (N. del E.). 
¿Hay que hacer fecundo el librecambio que pedimos para que a los cereales sustituyan la viña, los frutales y la ganadería, esto es, granjerías y cultivos que produzcan artículos de exportación? Pues las obras habrán de ser vías de comunicación. Con esto se consiguen tres cosas: una, que los jornaleros tengan jornal seguro; otra, que ese jornal sea lo suficientemente alto para que ahuyente la tentación de ir a buscar otro más remunerador en el extranjero; y por último, que ese jornal prepare y engendre otro y otros para lo sucesivo. Un ejemplo. La comarca de Ribagorza, en el Alto Aragón, era hace seis años un país pobrísimo, que daba gran contingente a la emigración: se abrió por él una carretera, y no cambió en nada su suerte, porque no tenía nada que exportar: llegó felizmente el convenio de 1877, y cambió repentinamente la faz de aquel país, que produce enormes cantidades de vino: la carretera construida 10 años antes entró en funciones: sin ella, el convenio le habría sido inútil, porque no habría podido sacar en condiciones económicas el vino; pero se juntaron en consorcio feliz esos dos elementos de prosperidad, el camino abierto y la frontera libre, y hoy materialmente nadan en la abundancia; los notarios se enriquecen haciendo escrituras de cancelación de créditos; antes era difícil hallar quien prestara al 12 por 100, y hoy es difícil, casi imposible, hallar quien quiera tomar prestado al 6: la propiedad ha aumentado de valor de tal suerte que hay propietario que ha sacado de vino en un año lo que había pagado poco antes en precio del viñedo: así es que los labradores se han reconciliado con su profesión, y si antes era difícil encontrar quien quisiera comprar tierra, hoy es difícil encontrar quien quiera venderla: los jornaleros, que antes ganaban de jornal 4 o 5 rs. cada día, y no durante todo el año, exigen ahora y obtienen el doble, 10 rs. Así, señores, la libertad de comercio ha hecho fecunda a la carretera y la carretera ha hecho fecunda a la libertad de comercio. La carretera dio trabajo a los jornaleros mientras se construyó, y, ahora que está construida, lo sigue 
dando en mayor escala: entonces se les pagaban 5 rs., ahora medio duro: entonces era eventual, ahora seguro: el jornal, antes extraordinario y transitorio de la temporada de la siega, tiende a normalizarse y hacerse permanente.*

Y esto me recuerda lo que me contestó cierto emigrante alicantino a una pregunta que le hice sobre las causas que inducían a sus paisanos a emigrar. "iAh, señor! —me dijo-: todo consiste en lo poco que vale el trabajo: hacemos la siega en España, y durante ella nos va bien, porque los salarios son altos; pero dura pocos días, y nos quedamos a lo mejor sin ocupación, o con un jornal tan miserable que no nos basta para vivir: así es que nos marchamos á África, porque allí la siega dura todo el año, o todo el año ganamos jornal de siega: si el año tuviese 12 junios, podríamos vivir, y esté V. seguro que no nos iríamos a África". Esto me dejó pensativo: el ciclo de la vegetación, me decía yo,** no se interrumpe nunca en el planeta: la humanidad vive en estado de siega permanente: en enero siega la mies en Australia y en Nueva Zelanda; en febrero, en la India; en marzo, en Egipto; en abril, en Siria, en Chipre y en Méjico; en mayo, en Persia, en Marruecos, Florida, Japón y China; en junio, en California, Kentucky, España, Sicilia, Italia y Mediodía de Rusia; en julio, en Iowa, Illinois, Inglaterra, Francia, Alemania, Italia, Austria, Polonia; en agosto, en Bélgica, Holanda y Dinamarca; en setiembre, en Suecia y en el Norte de Rusia; en octubre, en Escocia, y en algunos países de América; en Noviembre, en el Cabo y al Norte de Australia; en diciembre, en la Australia Meridional, en Chile y en los Estados del Río de la Plata: la humanidad vive en estado de siega permanente: ¿no podría, me preguntaba yo, vivir en estado de siega permanente el hombre? ¿No podría hacerse de la Península un planeta en pequeño, donde no se inte-

* En el folleto publicado por la Asociación para la Reforma Liberal de los Aranceles de Aduanas figuraban "(Aplausos)". (N. del E.). (N. del E.)

" ", me decía yo,": añadido a mano en el ejemplar del AHPH. 
rrumpiese nunca el ciclo de la vegetación? Y después de pensarlo mucho, me contesté que sí. La siega se distribuye por meses en el planeta, conforme a la distribución de las lluvias y de la temperatura: pues sujetemos las lluvias a régimen, inundemos el país con un sistema arterial hidráulico de canales, acequias y pantanos: sábese que el agua templa los rigores del invierno y los ardores del estío: por medio del agua, en los prados denominados marcite de la Lombardía, siguen creciendo las plantas y dando sus cosechas en los meses más crudos de la estación invernal: por medio del agua, en las huertas de Murcia y de Valencia siguen creciendo las plantas y dando cosechas dobles en los meses más calurosos del verano: donde no se dispone de riego, las plantas solo crecen y los jornaleros solo trabajan en las estaciones intermedias, en primavera y en otoño, y aun eso no siempre, pues depende de que llueva o de que no llueva. Construya, pues, el Estado canales de riego; delante de ellos huirá el trigo, tan ruinoso para nuestra patria; ocuparán su lugar los prados y vergeles, esto es, la ganadería y los frutales; abramos a estos productos vastos mercados en Europa y América, como se los estamos abriendo al vino, y los jornaleros ganarán 10 o 12 rs. todo el año, y habrán concluido para siempre las crisis alimenticias, y aquel pobre emigrante alicantino, que perdió de vista las playas de España con los ojos arrasados en lágrimas, podrá al fin restituirse a su patria, porque se habrá cumplido lo que él tenía por un ideal inasequible, que el año tenga 12 junios, y que desde enero hasta diciembre no le falte un solo día donde segar. (Aplausos).

En pos de los cereales desfilarán solemnemente las primeras materias, acaudilladas por el Sr. Carreras y González. Propónese discutir la tesis de si deben o no favorecerse las tendencias que se despiertan con tan viva energía entre los fabricantes a que los poderes públicos declaren de libre introducción y exentas de derechos las primeras materias que las industrias fabriles y manufactureras emplean para 
sus elaboraciones. No he de intrusarme yo en ese campo, que es de su exclusiva jurisdicción y competencia, por más que a ello me convide y aun tiente con tentación casi irresistible lo simpático que me es un tema que tan de cerca toca a la agricultura, cuya voz quisiera llevar aquí; y me limitaré, por tanto, como he hecho respecto de la cuestión primera, a recomendar a la atención del Sr. Carreras un aspecto del problema a que no suele darse gran importancia, y que tiene, sin embargo, más de un punto de contacto con la base 5. ${ }^{a}$ de la Ley Figuerola, que hemos venido a discutir: me refiero a la falta de lógica con que los proteccionistas piden y el Gobierno concede libertad de comercio para los ramos más importantes del trabajo nacional, y restricción casi absoluta respecto de otros que al lado de aquellos son insignificantes. Buscando el Sr. Sagasta una compensación a los males imaginarios que se supone ha de causar el tratado franco-español, decía:* "si alguna vez se perjudica alguna industria, en cambio se le puede proporcionar y se procurará proporcionarle con más facilidad las primeras materias que necesite". Y los fabricantes, que juran querer protección para todos los ramos de la producción nacional, aun en el caso de que hubiera de serles dañosa, a pesar que las tales primeras materias son ya de suyo una producción nacional, lejos de rechazar indignados esa promesa del Gobierno y de paralizar las gestiones oficiosas de sus representantes en Cortes, les salen al encuentro reclamando la rebaja con vivas instancias. ¿Y sabéis por qué? Porque los proteccionistas que ahora se estilan en España no son proteccionistas de verdad; son doctrinarios, híbridos, mestizos, proteccionistas y libre-

* En el ejemplar conservado en el AHPH aparece tachado antes de los dos puntos "el señor Sagasta", que sí figuraban en el folleto publicado por la Asociación para la Reforma Liberal de los Aranceles de Aduanas. En otro ejemplar conservado también en el AHPH (carpeta 113, 18) se había tachado "el Sr. Sagasta" de la línea anterior, mientras que se conservaba el segundo. ( $N$. del E.). 
cambistas de media sangre; parten la libertad y la protección en dos mitades, y toman una mitad de la una y otra mitad de la otra, para formar con las dos un contubernio tan nefando como el que inventó la conservaduría francesa del "justo medio" entre la soberanía nacional y la legitimidad histórica. Ahora voy a deciros hasta qué punto es justo ese medio que con tanto ardimiento sustentan los neoproteccionistas, fiados en que la agricultura es una pobre señora que lo aguanta todo con resignación porque no tiene voz para quejarse ni lengua para defenderse.

Ante todo, y para que podamos entendernos los que aquí hemos venido a reñir nuestro pleito ante el tribunal respetable de la opinión pública, y para que podáis seguir el curso de los razonamientos del Sr. Carreras, voy a fijar en términos precisos el valor de estos dos vocablos: materias primeras y productos elaborados. Vosotros convendréis conmigo en que estos dos conceptos son puramente relativos: lo que para la agricultura son productos, el algodón, el lino, el cáñamo, la seda, la lana, las pieles, la madera, el añil, el trigo, el vino, el aceite, para la industria fabril es primera materia; y viceversa, lo que para la agricultura es materia primera, las máquinas y las herramientas, los materiales de construcción, los medios de trasporte, los vestidos y el calzado, los abonos artificiales, muchos productos químicos, la barrilería, la botillería, etc., es producto para la industria. Puede decirse en cierto sentido, por más que parezca paradoja, que la misión de la agricultura se cifra toda entera en producir primeras materias para la industria, y que toda la misión de la industria se reduce a producir primeras materias para la agricultura (Aplausos).* Es verdad que los proteccionistas se empeñan en que no existe paridad entre uno y otro género de producción, entre uno y otro género de materias primeras, y combaten, v. g., el tratado franco-español diciendo que en él hemos hecho ven-

* "(Aplausos)»: añadido a mano en el ejemplar del AHPH. (N. del E.). 
tajas a los franceses respecto de productos que, como los tejidos, llevan mucha mano de obra, al paso que ellos nos han dado ventajas respecto de productos que apenas llevan mano de obra, como el vino. ¡Ojalá tuvieran razón! ¡Ojalá exigiera el vino tan poco trabajo que no hubiese sino construir grandes aljibes en el suelo y recoger por las canales de los tejados el mosto que pródigamente descargaran las nubes en lluvia torrencial! (Risas).* Pero, desgraciadamente, es el vino un producto que cuesta más de obtener que los tejidos de lana y de algodón. La botella de vino que se bebe un proteccionista el día que pronuncia un discurso contra el vino y contra el librecambio (Risas), ${ }^{* *}$ representa para los viticultores librecambistas las operaciones siguientes: romper y agostar la tierra, abrir las zanjas o los hoyos, poner en ellos los sarmientos o los barbados y enterrarlos; protegerlos contra la langosta, contra la sequía y contra el ganado; podar las vides, enrodrigonarlas, alumbrarlas antes de las lluvias, desbarbarlas, cavarlas, binarlas, estercolarlas, rebinarlas, castrarlas, regarlas cuando se puede regar; evitar que las yemas se hielen, por medio de nubes artificiales de humo o por medio de rogativas, a elección; refaldar los sarmientos, despampanarlos, despuntarlos, defender los racimos contra los muchachos, contra los tordos, contra los perros, contra el oídium, contra los agentes del fisco y contra la filoxera; azufrarlos; prevenir los efectos de la piedra, por medio de rogativas o por medio del seguro contra el granizo; vendimiar los racimos, clasificarlos, asolarlos en la era, trasportarlos al lagar, pisarlos, despalillarlos, dirigir la fermentación, lavar y azufrar los toneles, trasegar el vino, prensar el orujo, prevenir la fermentación acética, trasegarlo otra vez, embarrilarlo o embotellarlo y trasportarlo al depósito del comisionista o a la estación del ferrocarril. ¡Si creerán esos señores que todo

* "(Risas).": añadido a mano en el ejemplar del AHPH. (N. del E.).

** "(risas)": añadido a mano en el ejemplar del AHPH. (N. del E.). 
esto lo hacen los espíritus! Yo no encuentro diferencia por lo que respecta a la cantidad entre la mano de obra que requiere el vino y la que requieren los tejidos: la encuentro, sí, en la calidad: los tejedores trabajan en aposentos cerrados y a la sombra, frescos en verano, calientes en invierno, al paso que los viñadores trabajan a la intemperie, encorvado el cuerpo hacia la tierra, azotado por el viento y la lluvia, abrasado el rostro por la canícula, heladas las manos por el cierzo y la escarcha, vacío el estómago, porque el fisco les arrebata de las manos el pan; cubiertas de harapos las carnes, porque los fabricantes los condenan a desnudez perpetua; como si al ser expulsado del Paraíso el primer hombre, condenado a comer el pan con el sudor de su frente, le hubiera salido al encuentro la serpiente del proteccionismo para agravar la maldición de Dios, condenándole a no poderse enjugar ese sudor con el mismo lino y con el mismo cáñamo que cosechara. (Grandes aplausos).

Esto supuesto, señores, supuesta esa igualdad de condiciones del trabajo industrial y del trabajo agrícola, si los neoproteccionistas fueran proteccionistas de verdad, la divisa que fingen ostentar en su bandera de «bastarnos a nosotros mismos los españoles" la traducirían en protección para los productos de la agricultura, que son la primera materia que ellos emplean, y para los productos de la industria, que son las primeras materias que los labradores empleamos: si los neoproteccionistas fuesen proteccionistas de verdad, de igual modo que nos obligan a los labradores a comprar sus tejidos aunque sean más caros que los tejidos ingleses, nos comprarían las lanas, las hilazas y la seda con que se fabrican, aunque les saliesen más caras que las extranjeras. Y eso es precisamente lo que no quieren entender: prefieren comprar trigo de Odesa o de California, algodón de Egipto, lana de Buenos Aires o de Australia, seda de Lombardía, cáñamo de Riga y carbón de Newcastle, si les salen más baratos que el trigo de Castilla, el algodón de Motril, la lana de Extremadura, el cáñamo de Aragón, la seda de Valencia y el carbón 
de Belmez, de Espiel o de San Juan de las Abadesas. Esto les parece natural, y a mí también; pero lo que ya no les parece natural, lo que les subleva e irrita es que nosotros queramos imitarles, comprando nuestras primeras materias en Francia, en Bélgica o en Inglaterra, si nos salen más baratas que en sus fábricas de Málaga, de Valencia o de Barcelona. ¡Y esto sí que es irritante, señores! ¿Qué nuevo género de feudalismo quieren introducir en daño de la agricultura, obligándola a venderles barato y a comprarles caro, esto es, a darles a ellos más de lo que de ellos recibe? Suponed que las Cortes, en vez de mostrarse dispuestas a rebajar los derechos arancelarios que gravan las primeras materias de la industria, trataran de elevarlos, a fin de proteger esos ramos de producción española, la seda, la lana, las hilazas, el algodón, la madera, el carbón, etc.: al punto veríais los teatros de Barcelona convertidos en volcanes, y comisiones de obreros y de fabricantes camino de Madrid, levantando aquella tremenda campaña de protestas que promovieron los industriales franceses en 1871 contra los planes financieros de Mr. Thiers, fundados en el impuesto sobre las primeras materias; protesta tan formidable, tan apasionada, tan unánime que hizo naufragar el proyecto en el Parlamento, y produjo nada menos que una crisis presidencial. Y esta otra agitación a que acabamos de asistir, y que no ha concluido todavía, ¿de dónde nace, a qué obedece? Pues nace (permitidme que os lo diga en francés) de rivalité de métier, de que nosotros los labradores hacemos eso mismo que ellos harían, de que somos tan atrevidos y tan malos que también queremos baratas como ellos las primeras materias. Y precisamente en esto nos diferenciamos los unos de los otros: nosotros queremos baratas nuestras primeras materias y las suyas; ellos quieren baratas las suyas y las nuestras caras; solo así podréis penetrar la filosofía del motín de Barcelona, que al mismo tiempo que pedía aduanas nacionales cada vez más amplias en la frontera, para que no entren del extranjero los objetos que ellos producen y que nosotros 
consumimos, destruía e incendiaba los fielatos, que son las aduanas municipales, para que pasaran sin traba alguna que los encareciese los artículos que nosotros producimos y que consumen ellos. Nosotros somos librecambistas como productores y como consumidores: ellos son librecambistas como consumidores, y como productores, proteccionistas: son librecambistas para el algodón en rama y para la seda en rama porque les conviene comprarlos baratos, y proteccionistas para las telas de seda y de algodón porque les conviene venderlas caras: son librecambistas para las lanas y las hilazas de lino y de cáñamo porque les conviene, y proteccionistas para los tejidos de hilo y de lana porque no les conviene: son librecambistas para el petróleo en bruto porque les conviene, y proteccionistas para el petróleo refinado porque no les conviene; son proteccionistas para la salida de corcho elaborado porque les conviene, y proteccionistas para la entrada del corcho elaborado porque no les conviene; son librecambistas para la maquinaria y para el carbón mineral porque les conviene, y proteccionistas para el hierro con que esas máquinas se fabrican y para los productos que mediante el carbón se elaboran porque no les conviene; son librecambistas para todas sus primeras materias, pagando tan solo por ellas el 4 por 100, y proteccionistas para los géneros elaborados con ellas, haciéndonos pagar por ellas ocho veces eso, el 32 por 100; que de esta suerte, esa flamante escuela que se viene entre gemidos y amenazas invocando la justicia, pide, con efecto, justicia, pero no por su casa, siendo proteccionista para sí y librecambista para el prójimo, y ostentando dos caras, como el Jano de la mitología antigua, una que mira al cielo de la libertad, otra que mira al infierno de la protección y del despotismo. (Aplausos).*

* En el folleto original publicado por la Asociación para la Reforma Liberal de los Aranceles de Aduanas figuraba "(Estrepitosos aplausos)". (N. del E.). 
Acaso me objetará el neoproteccionismo que esto es muy natural, que todo el mundo hace aquello que más le* conviene. Pero yo le contesto que no: los labradores somos librecambistas para los tejidos de algodón y de hilo porque nos conviene, y para las hilazas de cáñamo y de lino y para el algodón en rama, a pesar de que no nos conviene; somos librecambistas para las lanerías y las sederías porque nos conviene, y para la lana y la seda en rama, a pesar de que no nos conviene; somos librecambistas para los vinos nacionales porque nos conviene, y para los vinos y aguardientes extranjeros, a pesar de que no nos conviene; somos librecambistas para la exportación de ganado vivo a Inglaterra porque nos conviene, y para la importación de carne muerta de Chicago, a pesar de que no nos conviene; que alguna vez había de haber en España personas y clases dispuestas a sacrificar sus conveniencias en aras de la justicia y a no llevar su conciencia por partida doble, como los neoproteccionistas la llevan, con mengua de la humanidad y escarnio de la justicia y de la lógica. (Aplausos).**

Pero ya, por fortuna, hemos principiado a salir del limbo los labradores, y podéis prepararos, por tanto, señores laneros y algodoneros, a tirar de la cuerda para todos o para ninguno. Hace siglos que os venimos pagando grandes primas, y cansados de ser vuestros primos, queremos ascender a hermanos, que es decir a iguales vuestros. Nosotros le pedimos al Estado poco menos de nada: lo que pedía desde el fondo de su tonel el filósofo griego al Magno Alejandro: que se aparte a un lado, que se retire y no nos quite el sol, a pretexto de que lo necesitáis todo para calentaros. Pues, ahora, oíd nuestra resolución: no consentiremos que el Estado os conceda más de lo que nos tiene concedido a nosotros: somos iguales ante la Constitución del Estado, y

* En el folleto original publicado por la Asociación para la Reforma Liberal de los Aranceles de Aduanas figuraba "les". (N. del E.).

** "(Aplausos)": añadido a mano en el ejemplar del AHPH. (N. del E.). 
queremos ser también iguales ante la ley fiscal. Puesto que os dejamos comprar vuestras primeras materias donde más os convenga, queremos reivindicar el derecho de comprar las nuestras donde más baratas las hallemos, puesto que no pedimos ni queremos para nuestros productos mercados artificiales, no nos impongáis mercados artificiales para vuestros productos; puesto que os permitimos que paguéis tan solo el 4 por 100 por vuestras primeras materias, que son nuestros productos, no queremos pagar más que el 4 por 100 por vuestros productos, que son nuestras materias primeras. Y optamos por esto, por que se tire la cuerda para los dos, y no optamos por que se suban los derechos uniformemente para unos y para otros al 32 por 100 , porque con el librecambio está ya demostrado que pueden ellos fabricar y cultivar nosotros, al paso que con el proteccionismo, si les hiciéramos pagar el 32 por 100 de la lana, del algodón, del cáñamo, de la seda, del carbón y de la maquinaria que consumen, les sería imposible trabajar, tendrían que pegar fuego a sus telares, y sus obreros se verían obligados a buscar en Bélgica o en Inglaterra un rincón donde instalar su artefacto y ganar el sustento de sus hijos a la sombra bienhechora del librecambio. (Aplausos).

Y si no, díganme: ¿por qué esos obreros encuentran jornal hoy en Cataluña? Precisamente por la parte de libertad que se mezcla en la amalgama doctrinaria de su sistema económico. Fijaos bien, señoras y señores, en este hecho singular que resuelve no pocas aparentes contradicciones. Como los neoproteccionistas tienen una doble naturaleza, como son a un mismo tiempo y por mitad proteccionistas para lo que venden y librecambistas para lo que compran, se produce en su cerebro un curioso fenómeno de inversión de imágenes: todos los males que achacan al librecambio los causa el proteccionismo; todos los bienes que aguardan del proteccionismo los produce el librecambio. Sus capitales crecen, sus fábricas prosperan a ojos vistas; pero crecen y prosperan, no por la protección, sino a pesar 
de la protección; a la manera como España se va redimiendo lentamente de su secular caída, no por obra de los partidos políticos, sino a pesar de ellos y de la desastrosa gestión de sus Gobiernos.

Otra cuestión que ha de ventilarse en este meeting es la relativa al influjo bienhechor que debe ejercer y ejercerá el planteamiento de la base $5 .^{a}$ en el desenvolvimiento de las industrias fabriles y manufactureras, y a la sinrazón con que los industriales se alarman y atemorizan al Gobierno, haciéndole creer que la vida de sus manufacturas y la suerte de sus obreros depende de ese inicuo sistema que protege a unos cuantos centenares de capitalistas, sacrificándoles 17 millones de españoles. Antes de probar, con la experiencia de lo pasado y los guarismos irrecusables de la estadística, que no ha de recabar la industria menores beneficios que la agricultura de la reforma arancelaria, he de hacerme cargo de una acusación insensata que vienen repitiendo hace algunos meses los proteccionistas contra los partidarios de la libertad mercantil, contra los labradores españoles. Dicen que lo que queremos nosotros es arruinar a Cataluña, matar todas sus industrias, destruir los capitales comprometidos en la fabricación y hacer emigrar a sus obreros. No lo creáis, señores obreros; no lo creáis, señores fabricantes: no queremos vuestro aniquilamiento, sino vuestra prosperidad: no nos causan envidia, sino orgullo, vuestras fábricas, y deseamos que las multipliquéis, porque España necesita de vosotros. No queremos enmohecidos vuestros telares, ni cubiertas de telarañas vuestras chimeneas, ni quebradas vuestras sociedades fabriles, ni hambrientos y en huelga forzada* a sus obreros: la única huelga que los labradores deseamos es la de los partidos políticos, para que una vez siquiera dejen el país abandonado a su propia inspiración y que se gobierne a sí mismo. Yerra pro-

* "forzada": añadido a mano en el ejemplar del AHPH. (N. del E.). 
fundamente quien diga que el porvenir de España está solo en la agricultura: no; el porvenir de España estriba en la agricultura y en la industria juntamente: de unos y de otros, fabricantes y labradores, necesita igualmente nuestra patria. La vida nacional no se halla reducida a los estrechos límites de la Península: tenemos que exteriorizarnos por África, por América, por Oceanía, y, para exteriorizarnos, no nos son menos necesarios los tejedores que los soldados, no nos es menos indispensable la marina mercante que la marina de guerra. Por la extensión de nuestras costas y de nuestras colonias, somos la cuarta potencia marítima, y necesitamos ser, por tanto, cuando menos, la cuarta potencia mercantil y la cuarta potencia naval: desgraciadamente, en uno y en otro respecto, somos la octava o la novena, y tenemos que apresurarnos mucho si hemos de equilibrarnos con los demás países y tomar parte activa en el concierto de la civilización. Pues bien; nosotros, labradores, que sostenemos el presupuesto de la nación (pues el impuesto que satisfacen las industrias protegidas apenas alcanza para pagar su escasa soldada a los carabineros), nosotros, que levantamos las cargas de la nación, reconstituiremos la escuadra, que nos es indispensable para cumplir nuestros destinos y realizar nuestros ideales exteriores; ellos, los fabricantes, deben reconstituir la marina mercante, sin la cual, la acción de los guerreros es punto menos que ineficaz. ¿Y queréis que os diga cómo costearán los labradores los gastos extraordinarios y cuantiosísimos que supone la adquisición de tantos buques de guerra como España necesita? Dedicando a esa atención sagrada los 700 millones de reales que el actual régimen aduanero nos obliga a pagar cada año a los fabricantes. ¿Y sabéis cómo reconstituirán estos la marina mercante, en proporción armónica con nuestro poder naval y con nuestras colonias y poblaciones marítimas? Obligándoles a buscar la compensación de esos 700 millones, no donde se la intenta dar el Gobierno, por medio de mezquinas ventajas sobre la 
introducción de las primeras materias, sino fuera de la Península; obligándoles a abrirse nuevos mercados fuera de Europa, donde se los abren los belgas, los ingleses, los franceses, los alemanes y los italianos, en América, en Oceanía, en África; sobre todo, en África, donde la ausencia de las manufacturas catalanas entraña un peligro gravísimo para el porvenir de nuestra patria. ¡Ah, señores fabricantes! ¿Cómo habíamos de renegar de vosotros y de vuestros tejidos? Si el vino constituye hoy nuestro principal artículo de exportación y el lazo social que nos liga con Europa, que es el presente, el hilo y la tela de algodón deben ser el vínculo que nos enlace con África, donde está una gran parte de nuestro porvenir. En Marruecos, en el golfo de Guinea, en las posesiones africano-portuguesas de Angola y Mozambique, habitan infinidad de razas que necesitan de nosotros para salir del estado de abyección en que se encuentran, y a las cuales necesitamos nosotros para asegurar a nuestra raza un porvenir colonial digno de nuestro pasado. Ahora bien; preguntad a los ingleses, a los franceses y a los belgas cómo se civiliza en África y cómo se conquista a sus moradores, y os dirán que no tanto por los soldados y los misioneros cuanto por los industriales. La gota de sudor del tejedor redime más hombres que la gota de sangre del guerrero: el telar conquista más que el chassepot: la lanzadera tiene más fuerza que la bayoneta: la bala de algodón, convertida en tejido, va más lejos y penetra más hondo que la bala de hierro lanzada por el cañón de Armstrong o de Krupp. Yerra profundamente quien piense que una madeja o una pieza de algodón es un cuerpo pasivo e inerte, como un pedazo de madera o una piedra desprendida de la montaña: una madeja de hilo o una pieza de algodón es un ser vivo, en quien el tejedor y el hilandero han infundido su propia alma y condensado todos los progresos y todas las edades de la historia. El fabricante, asistido por el naviero, va envolviendo calladamente, con el eterno hilo que sale de su bobina, el continente africano, y tejiendo sobre él, araña 
misteriosa, la inmensa tela en que ha de prender las almas de 200 millones de negros y ganarlas a la causa de la civilización. La pieza de tela que el comerciante deja en la costa es un ser vivo e inteligente; alienta, palpita, tiene un alma, penetra en el interior inexplorado del continente, bautista de la civilización, mucho antes que los más audaces exploradores; habla el lenguaje del obrero que la ha creado, es un hijo amoroso del pueblo a quien debe el ser, canta las grandezas de su patria en medio de los negros atónitos, abriendo en su cerebro nuevos horizontes y despertando en su corazón poderosas corrientes de simpatía, que luego se traducen en vastos imperios coloniales; instruye, corrige, moraliza; es la antorcha mitológica que corre de selva en selva y de río en río, ahuyentando la eterna noche en que está sumido el continente, encendiendo en el corazón de las razas que lo* pueblan la luz de nuevos ideales, antes por ellas no sospechados, suavizando sus instintos selváticos y abriendo el camino al maestro, al misionero y al soldado. Así como las razas inferiores van cubriendo con ella la desnudez de su cuerpo, descórrese como por arte de magia el velo espeso que interceptaba el paso de la luz a su inteligencia, y la tribu salvaje que siente esa iluminación interior, y a su influjo germinar en confuso tropel semilleros de ideas, dormidas hasta entonces, bendice a esa otra raza bienhechora de tejedores que completa la obra del Calvario, abriéndoles de par en par las puertas del porvenir y atrayéndolas a la vida de la historia y a la comunión de la humanidad. (Grandes aplausos).

Vean, pues, los señores fabricantes cuán noble papel les asignamos en la obra de nuestra regeneración y de nuestro engrandecimiento. ¡Atrévanse a decir ahora que somos enemigos de la industria, y que queremos y que procuramos su ruina! Pero hay más: no los necesita España solo para eso,

* En el folleto original de la Asociación para la Reforma Liberal de los Aranceles de Aduanas aparecía "los". (N. del E.). 
ni urge solo por eso la reforma arancelaria por que abogamos; los necesita también para que le ayuden a resolver uno de los más graves problemas sociales que al presente la preocupan: el problema de la emigración, tan enlazado con el de las subsistencias. Y voy a apuntar el porqué. Ya he anticipado que las piezas de algodón hacen en un respecto lo que podría hacer el obrero que las ha tejido, y que por esto, si yo fuese partidario de la protección, y estuviese en mi mano, en vez de otorgarla en forma de derechos arancelarios sobre la importación, la concedería en forma de primas a la exportación: así, por ejemplo, Inglaterra no tiene hombres que enviar para poblar el África, como los tuvo para poblar la América; pero envía a los negros cargamentos de piezas de algodón, y esas piezas, en las cuales ha estampado el genio de la raza británica, hacen veces de hombres, y por medio de ellas va entrando en posesión del continente africano. Pues ahí tenéis la clave del problema: en esa ecuación existente entre el operario y su obra, entre el hombre creador y los productos hijos de su inteligencia y de sus manos. ¿Por qué emigran los hombres en España? Porque no emigran las piezas de algodón. ¿Por qué hay en África 100000 trabajadores españoles? Porque no han ido en lugar suyo 100 millones de metros de tela de algodón. (Aprobación).* No necesito entrar en largas explicaciones: apuntada la causa, vosotros deduciréis las consecuencias. Los aranceles protectores han sido impotentes para que la industria enriqueciese a España, y en cambio, han impedido que la enriqueciese la agricultura. Las industrias protegidas han sido el perro del hortelano. Si el librecambio hubiera penetrado en España hace 40 años, al mismo tiempo que en otros países, el mercado que los algodoneros tienen solo en la Península lo tendrían en África; el mercado que los vinateros han tenido hasta hace poco solo en la Península lo tendrían en Inglaterra: los tejidos y el cultivo (N. del E.).

* "(Aprobación).": añadido a mano en el ejemplar del AHPH. 
de la vid habrían alcanzado un desarrollo triple o cuádruplo al que tienen hoy día; el jornal se habría duplicado o triplicado, y los 100000 emigrantes españoles que hay en Argelia y los 150000 o 200000 de la América del Sur estarían en la Península, la mitad tejiendo lana y algodón, la otra mitad plantando y vendimiando, contentos los unos y los otros con vivir en estado de siega permanente, que duraría para ellos todo el año, en vez de los 15 días que ahora dura y que les obliga a emigrar en busca de una patria menos cruel que la que les ha dado nacimiento. (Aplausos).

Ya oigo a los proteccionistas objetarme que esto son palabras y buenas intenciones, de esas de que está empedrado el camino del Infierno, pero que los hechos las contradicen; que, para que fuesen sinceros nuestros deseos, deberíamos renunciar a la base $5 .^{\mathrm{a}}$, monstruo feroz entre cuyos dientes peligra acabar trágicamente la industria española. Pero también en esto se equivocan de medio a medio. ¿No dice el pueblo en un refrán que "por el hilo se saca el ovillo y por lo pasado lo no venidon? Pues recuerdo que un diputado catalán, el Sr. Fabra, que, por cierto, no es librecambista, decía en las Cortes de 1878 que «el desarrollo de nuestra industria ha coincidido siempre con las reformas arancelarias". De tal suerte, el pasado me responde de lo porvenir. Sirva de resumen este recuerdo a las demostraciones históricas y aritméticas que me proponía bosquejar, y para las cuales no me alcanza ya el tiempo, pues me dicen que he consumido mucho más del que tenía señalado.

He concluido, pues, y dejo libre la tribuna a los oradores del meeting. Yo deseo, señoras y señores, que saquéis de sus discursos y que llevéis en el alma, al retiraros de este recinto, con la representación que tenéis de la opinión pública, el convencimiento íntimo de que las consecuencias que ha de producir la reforma arancelaria serán diametralmente contrarias a las que por el proteccionismo se anuncian, por lo mismo que su naturaleza es opuesta a la que pretenden atribuirle; que el Sr. Sagasta ha sido víctima 
de un espejismo, creyendo ver en la base 5. ${ }^{\text {a }}$ el monstruo que tenía delante abrazado al sistema protector. Es achaque éste común a los proteccionistas. Ellos llaman a la protección justicia, yo la llamo despojo; ellos la llaman democracia, yo la llamo oligarquía; ellos la llaman fomento del trabajo nacional, yo la llamo fomento de los trabajos que padece el pueblo; ellos la definen como definía el jurisconsulto romano la naturaleza del derecho, "dar a cada uno lo suyo"; yo la defino como definía el pueblo español, hace ya tres siglos, en un refrán chispeante de gracia y de verdad, al honrado Concejo de la Mesta, que era la institución proteccionista de aquel tiempo: "QQué es mesta? Sacar de esa bolsa y meter en esta". ¡Ahí tenéis la "vera effigies" del proteccionismo! (Grandes y prolongados aplausos). 
Discurso pronunciado en el meeting de la Asociación para la Reforma Liberal de los Aranceles de Aduanas sobre el tema

«ESTADO ACTUAL DE LA CUESTIÓN ARANCELARIA"

Celebrado en el Teatro de la Comedia de Madrid el día 24 de junio de 1883 



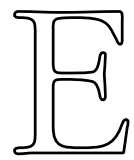

L SR. COSTA: Señoras y señores: Había hecho por este año voto de silencio, entre otras razones, que al público no le interesan, porque yo tengo la idea de que los españoles hablamos mucho y estudiamos poco, y que una de las cosas que más y con más urgencia necesitamos es aprender a callar. Por esto no me habéis visto en meetings, ni en conferencias, ni en debates. Pero esta tarde ha sucedido que uno de los oradores anunciados para esta solemnidad ha caído enfermo, D. Gabriel Rodríguez; que a otro le ha sido imposible venir, por ocupaciones perentorias, D. Segismundo Moret; y, para no defraudar tanto al público que honra este acto con su asistencia, mis compañeros de Asociación me han instado y el digno Presidente me ha constreñido a que llene, siquiera materialmente, un paréntesis de 15 minutos y prepare los ánimos para el desenlace.

El Sr. Ruiz de Castañeda nos ha hablado de tratados de comercio; el Sr. Figuerola, de reciprocidad; y el Sr. Pedregal, de primeras materias. Precisamente he recibido hace poco rato un telegrama que, aunque no tiene sino 25 palabras, abarca en síntesis perfecta esos tres aspectos de la cuestión arancelaria; mi discurso (quiero concederme el lujo de llamarlo así) va a consistir en exponer los antecedentes de ese documento postal, para que podáis comprender mejor su alcance y su sentido.

Me encontraba yo el verano pasado en un pueblo del Pirineo de Aragón, con motivo de celebrarse la fiesta prin- 
cipal de su santo patrono, que es san Roque. Estaba en una era, al caer la tarde, viendo bailar a la gente moza, y departiendo con los viejos del lugar sobre cosechas y sobre contribuciones, que son el único motivo de preocupación en las poblaciones rurales, cuando la conversación, rodando de uno en otro asunto, vino a caer sobre el proyecto de decreto de primeras materias, cuyo articulado habían publicado por aquellos días los periódicos. Me causó asombro ver a aquella asamblea, compuesta de destripaterrones y hacendistas de secano, tan enterada del asunto, y no me costó poco trabajo convencerles de que no tenían razón en demostrar cierta inclinación al proteccionismo y cierta malquerencia al proyecto en cuestión, cuando pocos meses antes habían escrito a su diputado provincial para que reclamase del Gobierno la pronta conclusión del tratado con Francia. Así es que hubo momento en que el debate se salió del diapasón normal, y algunos mozos se acercaron movidos de la curiosidad, y se desbarató el baile. Voy a trasmitiros el pensamiento de aquellas buenas gentes, en la misma forma metafórica en que lo expresaron.

La idea suya puede resumirse en estas palabras: "Los industriales son unos seres privilegiados y felices: siempre les da el sol de cara: el Gobierno español es alternativamente proteccionista y librecambista, según las lunas; cuando es proteccionista, los fabricantes ganan; nosotros que somos el cántaro, hemos dado contra la piedra: cuando le da por ser librecambista, los fabricantes ganan también; la piedra ha dado contra el cántaro. Base 5. a: las Cortes la resuelven de modo que queden contentos los fabricantes de telas y descalabrados los labradores. Pero, aunque descalabrados nosotros, ellos se ponen la venda, $y$, para que se la quiten, el Ministro de Hacienda discurre una compensación: libertad de introducción de primeras materias. Es decir, otra vez descalabrada la agricultura, porque esas primeras materias de la industria manufacturera son los productos de la industria agrícola". 
Como era natural, yo me esforcé en hacerles comprender que estaban en un error, pues no es justo que, porque seamos tuertos de un ojo, hayamos de arrancarnos el otro; pero uno de los mozos me atajó diciendo: "Mire Vd., nosotros no sabemos explicarnos, porque no hemos estudiado teología, pero a mi manera yo le diré a $\mathrm{Vd}$. lo que pensamos los labradores de eso que Vdes. llaman el librecambio, tal como nos le da aderezado el Gobierno". Y empuñando la guitarra, y tomando la vOZ de la agricultura, me cantó en las barbas, entre los aplausos de sus compañeros, la popular canción:

\section{Ni contigo ni sin ti tienen mis penas remedio; contigo, porque me matas, $\mathrm{y} \sin$ ti porque me muero.}

Un tío suyo, ganadero rico, que estaba sentado a mi derecha y que no había visto con buenos ojos que su sobrino pusiera en música lo que él creía que iba a costarle la ruina, me refirió el siguiente cuento: "Hace bastantes años, vinieron al pueblo, en tal día como hoy, dos señores, parientes del cura y del maestro; uno, director de una fábrica de tejidos de Barcelona, y otro, cosechero de vinos de Cariñena. Se hicieron amigos, y salieron una mañana a cazar juntos: en todo el día, por miedo* de espantar la caza, no hablaron de protección ni de librecambio; pero, a pesar de esta precaución, no cogieron sino una perdiz, que mató el aragonés, y un mochuelo, que por equivocación derribó el catalán. Al regresar, había que partir la caza. "Mira — dijo el de Barcelona al de Cariñena-, llévate tú el mochuelo y yo me quedaré con la perdiz, y si no te parece bien, me llevaré yo la perdiz y te quedas tú con el mochuelo". "A ver, a ver — dijo el aragonés algo amostazado—: vuelve a hacer el

* En el folleto publicado por la Asociación para la Reforma Liberal de los Aranceles de Aduanas aparecía "medio". (N. del E.). 
reparto, porque me parece que las dos veces haces caer hacia ti la perdiz, y que las dos veces me echas a mí el mochuelo". Moraleja del cuento, añadía el malicioso aldeano que me lo contaba: los labradores, a pesar de que somos los más, tenemos tan mala mano para sacar diputados que, cuando decretan la protección, es protección para los productos de la industria, que es lo que conviene a los fabricantes, y no para los productos de la agricultura, que es lo que nos convendría a nosotros; cuando decretan el librecambio, es librecambio sobre los productos de la agricultura, con achaque de primeras materias, que es lo que le conviene a la industria, y no sobre los productos de la industria, que es lo que nos convendría a los labradores y ganaderos. Ya ve Vd., pues, cómo de los dos modos se comen ellos la perdiz y cómo las dos veces tenemos que cargar nosotros con el mochuelo". (Grandes aplausos).

Ya iba yo a replicarle, oponiendo a su historieta el cuento de los dos cocheros, que nos ha referido nuestro sabio maestro el Sr. Figuerola, cuando el boticario del pueblo, que además de boticario es propietario de viñas y que formaba parte del corro, se adelanta, y con cierto tono de misterio y de enfática solemnidad me dice lo siguiente: "Yo poseo una receta mágica para hacer una cosa que a Vd. le ha de parecer imposible: que los fabricantes y obreros barceloneses, y quien dice barceloneses dice malagueños, valencianos o de cualquier otra ciudad, se acuesten una noche lo que son, proteccionistas, y amanezcan al día siguiente librecambistas, y no así como quiera, sino rabiosos, y corran a la frontera a prender fuego a las aduanas, y vengan a Madrid a reclamar con catalana energía, calada la barretina hasta los ojos, que se den por transcurridos todos los plazos de la base $5 .^{a}$, y se plantee una $6 .^{a}$, y si no basta, una 7. ${ }^{\mathrm{a}}$ y una 8. ${ }^{\mathrm{a}}$, reduciendo los derechos fiscales hasta parar en cero". Excuso deciros, señores, el salto que di sobre la piedra en que estaba sentado, al oír una cosa tan estupenda. «iLa fórmula, la fórmula!, le grité aturdido: venga la fór- 
mula!". "Pues es muy sencillo - me contestó con una sonrisa beatífica-: ¿no ve Vd. cómo estos labradores se van convirtiendo a la protección por obra y gracia de una ley librecambista sobre primeras materias? Pues ya sabe Vd. que yo soy boticario homeópata: similia similibus: deme Vd. una ley proteccionista sobre primeras materias, y cate $\mathrm{Vd}$. a los fabricantes librecambistas enragés. Y para que no se queme Vd. las cejas el día que llegue a tener mano en el Ministerio de Hacienda, aquí le traigo hecho el decreto con su preámbulo y todo". Y con efecto, desplegando un papel, me leyó el siguiente proyecto de decreto, que por lo curioso, vale la pena que le prestéis vuestra atención:

"Hace tiempo que vienen dirigiendo exposiciones a este Ministerio las ligas de contribuyentes, las sociedades económicas de amigos del país, y las diputaciones y ayuntamientos de 40 provincias, instando reformas profundas en los aranceles de aduanas en sentido protector y prohibitivo; y aunque hasta ahora, siguiendo la costumbre de este centro en casos tales, no se les ha hecho ningún caso, los exponentes acentúan sus quejas y reiteran sus primeras representaciones con tan vivas instancias que no ha podido menos de parar la atención en las razones que aducen en abono de su pretensión, y atenderla en todas sus partes, estimándola justa. Manifiestan los exponentes que para cubrir los gastos de cría y de cultivo, y poder seguir satisfaciendo los crecidos impuestos que agobian a la agricultura, necesitan expender sus productos a un precio superior en un 30 por 100, cuando menos, a los corrientes hoy en España; que habiendo encontrado el suelo de la Península empobrecido y agotado por un cultivo expoliador de veinte siglos, y, además, escaso en vías de comunicación y canales de riego, y careciendo, por causas ajenas a su voluntad, del crédito, del capital y de la cultura que son indispensables para introducir los perfeccionamientos generalizados ya de mucho tiempo en países más afortunados, sus cereales no pueden sostener la competencia con los de Califor- 
nia, ni su ganadería con la carne procedente de Chicago, ni las lanas de sus rebaños con las de Australia y Buenos Aires, ni sus cáñamos con los de Riga, ni sus sedas con las de Lombardía, ni sus aceites con los de Niza, ni sus arroces con los de la India; añaden que, si no se acude prontamente a proteger estos ramos de producción, que dan trabajo a 8 millones de habitantes, se verán envueltos en la ruina total que amenaza a la industria de la tierra, y tendrán que emigrar a países donde, como en Marruecos, se halla tan considerada la agricultura que en obsequio suyo se mantiene el régimen prohibitivo; que a los fabricantes se les protege con un derecho medio arancelario de 32 por 100, y que esta protección es justo extenderla a los labradores, y con más razón aún, por cuanto es mucho más difícil liquidar o transformar un olivar o un viñedo que una manufactura; que con semejante medida, se desarrollaría el cultivo del algodón y la cría de ganados, según puede conjeturarse juzgando por lo sucedido con la caña de azúcar; y, por otra parte, se paralizaría el movimiento de emigración, de tan funestas consecuencias para el porvenir de nuestra patria, y se determinaría por la inversa corrientes de inmigración, primero entre nuestros compatriotas establecidos en Argelia y América del Sur, y después, entre los extranjeros mismos; que representando las primeras materias que importan los industriales en año ordinario, por concepto de algodón, hilazas, seda, lana, cueros, carbones, máquinas, etc., un valor de 800 millones de reales, imponiéndoles un derecho protector de 32 por 100 , la renta de aduanas aumentaría los ingresos en muy cerca de 250 millones cada año, suficientes a enjugar el déficit de la Hacienda nacional y a construir carreteras y canales en beneficio de la riqueza del país; que las clases jornaleras, viviendo menos ahogadas que al presente, saldrían del estado de atraso y de incultura en que se hallan, y que tan a menudo les echan en cara los industriales privilegiados, que se enriquecen y progresan a expensas de la agricultura; que, aun cuando con esa medida se resintiera 
algún tanto la industria manufacturera nacional, no trascendería el quebranto al Tesoro público ni a la riqueza del país, no solo por lo insignificante de las cifras a que asciende el impuesto de subsidio de las industrias que hoy ejercen el monopolio de la protección, sino porque no exportan cantidad alguna apreciable al extranjero; y añaden, finalmente, que, en último extremo, no tienen inconveniente en tomar a su cargo la manutención de los obreros que queden sin ocupación por consecuencia de la reforma, pues, aun cuando esos obreros fuesen 50000 , sus pensiones no costarían a los exponentes más de medio millón diario, en cambio de lo cual ganarían un millón y medio que la protección les cuesta cada día.

Estimando tan justas razones, este Ministerio; considerando que la ley debe extender sus beneficios por igual a todos los productores y contribuyentes, ya que por igual les alcanzan los gravámenes y las responsabilidades; teniendo en cuenta que los representantes de las industrias protegidas han declarado repetidamente en las Cortes que querían protección para todo y para todos, lo mismo para el trabajo agrícola que para el trabajo fabril y manufacturero, y que Cataluña es proteccionista hasta en lo que le perjudica; haciendo, por último, extensivas estas consideraciones a otros importantes ramos de producción, como la fabricación de máquinas y la extracción de hullas y lignitos, a reserva de dar cuenta en su día a las Cortes, decreta:

Art. $1 .^{\circ}$ A contar del $1 .^{\circ}$ de julio próximo, las lanas, sedas y algodón en rama, hilazas de lino y cáñamo, trigo, vino, aceite, carne, cueros y pieles, máquinas, carbón y buques mercantes pagarán a su introducción en España el 32 por 100 de su valor.

Art. 2. ${ }^{\circ}$ Para atajar el contrabando que pudiera desarrollarse por consecuencia de lo prevenido en el artículo anterior, se aumentará en 5000 individuos el cuerpo de carabineros". (Grandes aplausos). 
No bien acabó de hablar el boticario vinicultor, la rústica asamblea hizo lo mismo que acaba de hacer la cultísima que está aquí congregada; rompió en un aplauso, en el cual creo que tomaron parte hasta las mozas, que ya se habían olvidado del baile. Solo uno de los concurrentes se abstuvo de aplaudir, y aun tomó la palabra para protestar contra este proyecto de restablecimiento del régimen protector en toda su desnudez. Era un viejo, curtido por el sol, de exterior humilde, que pasa entre sus convecinos por hombre reflexivo y de muchas sentencias, que posee una pequeña fortuna en olivos, y que no ha leído en toda su vida más que dos periódicos, a los cuales está suscrito desde su fundación: El Comercio Español, de Madrid, y El Boletín del Fomento de la Producción Nacional, de Barcelona. "Ese proyecto de decreto - les dijo- es una herejía y esos aplausos vuestros un sacrilegio. ¡Ir al librecambio por el camino del proteccionismo! ¡Qué monstruosidad! Es como si para ir a Cádiz tomarais el camino de París. Además, el fin nunca justifica los medios. ¿Os parecería bien que, para abolir la pena de muerte, empezáramos por ahorcar a los verdugos y a los magistrados de las audiencias? Claro está que mejor sería que la reforma se extendiese a todo el arancel, es decir, a las primeras materias de la agricultura, que son los productos de la industria, y a las primeras materias de la industria, que son los productos de la agricultura; pero ya que esto, por lo visto, no es posible, unos u otros han de empezar; y puesto que los fabricantes están tan empedernidos y obstinados en el error, puesto que están tan ciegos que sin duda la oscuridad de sus fábricas y el humo de sus chimeneas les entenebrece el entendimiento, seamos los primeros en ceder nosotros, los labradores, que no tenemos para alumbrarnos otra luz que la del sol ni nos guiamos por otro discurso que el de la razón natural; dejémosles ir a comprar su lana, su seda, su algodón, su aceite, su trigo, su lino, su cáñamo y su arroz donde quieran, que esto, sobre sernos ventajoso a nosotros mismos, que si perdemos por 
un lado como vendedores de primera materia, ganamos por otro como compradores de producto, nos autoriza a reclamar el año que viene que se haga con los fabricantes lo que se ha hecho con nosotros, y poco a poco iremos dando en tierra con esa última reliquia de la antigua esclavitud. Yo estoy convencido de que con la agricultura ha de suceder lo mismo que ha sucedido con la industria; que toda reforma arancelaria en sentido liberal ha ido seguida de un período de actividad y de desarrollo.

Así, cuando se redujeron por el año 1863 los elevadísimos derechos protectores que pesaban sobre el papel de fabricación extranjera, el proteccionismo se alarmó, considerando herida de muerte esta industria y condenadas a quedar desiertas las fábricas nacionales, bien halladas con el monopolio: no se les hizo caro; la invasión anunciada de papel extranjero se consumó, y, sin embargo, las fábricas que había en aquella fecha, lejos de arruinarse y desaparecer, se duplicaron, contándose hoy 37, en vez de 17 que eran entonces. Cuando se celebró el convenio de 1877, tan favorable a nuestros vinos, el proteccionismo anunció en el Congreso que sería dañosísimo para la producción española, que no tardaríamos en arrepentimos, y que la renta de aduanas descendería rápidamente en un 25 por 100. ¿Se realizaron los negros vaticinios de esa eterna ave de mal agüero que se llama el proteccionismo? Juzgad vosotros: antes de la revolución de septiembre, importaba la industria algodonera en España 17000 toneladas de algodón en rama: en 1876, un año antes del convenio, más del doble, 38000; en 1880, es decir, tres años después, casi el triplo, 45000. Con la renta de aduanas sucedió al revés de lo anunciado: en vez de disminuir un 25 por 100, aumentó en un 25 por 100, Y en parecidas proporciones creció la importación de hierro colado, flejes, acero, hoja de lata, máquinas, buques mercantes, maderas, hilaza, algodón y lana en rama, cueros y pieles. En la primavera pasada decían los proteccionistas en el meeting de Barcelona que 
si se aprobaba el tratado con Francia, tendrían que emigrar al extranjero los 50000 obreros que trabajan en algodón; y lo que ha sucedido es, según la estadística de la Gaceta, que este año ha pasado por las aduanas más algodón en rama que el año pasado, y he de pensar piadosamente que los catalanes lo compran para hilarlo y para tejerlo; yo no puedo suponer que lo compren para prender fuego otra vez a los fielatos, como hicieron hace pocos meses.

Pues bien; yo tengo la seguridad de que otro tanto sucederá con la agricultura, porque tengo la experiencia de que así ha sucedido otras veces. No hay clamoreo ni agitación comparable a la que movieron los cosecheros de Castilla cuando se redujo el derecho protector de los cereales a 10 rs. fanega: al decir de ellos, la ruina de Castilla era inevitable; pero no se les hizo caso; los hechos han venido a probar que la medida liberal no llevaba aparejada su ruina, y los agricultores, en su mayoría convertidos al librecambio, votaron el tratado con Francia y convierten en viñedos los antiguos campos de trigo. Lo mismo había sucedido antes en Inglaterra: la agricultura atacó rudamente la reforma de Peel, pronosticando su total ruina si se planteaba; y, sin embargo, nadie recabó tantos beneficios de esa reforma como la agricultura, hoy, a poder del desengaño, librecambista. Otro tanto ha sucedido después en Cataluña: los labradores combatieron con todo género de armas, lícitas y vedadas, el convenio de 1877, por juzgarlo ruinoso para España en general, y muy especialmente para Cataluña; y, sin embargo, nadie ha obtenido de él tantos provechos como la agricultura catalana. Mil millones vale el vino que exportamos cada año; pues bien, como el convenio se hizo en favor de los vinos comunes, no de los generosos ni jerezanos, como, además, Cataluña es fronteriza con Francia, la mitad de los vinos exportados procede de esas provincias o sale por sus puertos, y a ellos va a parar la mitad de ese río de oro que los franceses envían de retorno. Y como los labradores disponen de recursos que antes no tenían, gas- 
tan más, compran más géneros a los industriales, y así se explica ese prodigioso aumento en las cifras de importación de algodón, lana, hilazas, máquinas y carbón, y esa prosperidad creciente de las poblaciones fabriles de Cataluña, que las demás provincias españolas contemplan con ojos de envidia; por donde el convenio ha venido a redundar en provecho de la agricultura que lo pedía y de la industria que lo rechazaba, que en esto se parece a la Providencia de Dios la libertad, que hace llover sus beneficios por igual sobre los justos que la invocan y sobre los injustos que la maldicen y reniegan. Ese gran argumento, el éxito, ha convencido ya a los labradores catalanes, que componen la mayoría de Cataluña, devota hoy de las ideas librecambistas: yo espero confiadamente que no tardarán en seguirles las industrias lanera y algodonera, y si los Sres. Figuerola y D. Gabriel Rodríguez viven tantos años como yo les deseo, he de verles salir diputados en unas mismas elecciones por los seis distritos fabriles de Reus, Tarrasa, Sabadell, Mataró, Manresa y Barcelona. (Grandes aplausos).

He nombrado de intento — siguió diciendo el lugareño- las industrias lanera y algodonera, porque son las únicas que tienen alguna importancia en España, y puede decirse también las únicas que mantienen enhiesta la bandera proteccionista y hacen frente a las doctrinas del librecambio. No he de negar yo que tal o cual industria fuera de esas, tan insignificante que apenas figure por su nombre en las estadísticas aduaneras, no pueda resistir la competencia ni seguir viviendo desde el momento en que dejemos de subvencionarla los labradores. Me permito dudarlo, entre otras razones, porque habiendo dicho un diputado librecambista en las Cortes en abril último que el argumento de ruina de las industrias por efecto de los aranceles ha pasado ya de moda, le contestó otro diputado proteccionista que lo que ha pasado de moda son los 12000 telares de seda que había en Valencia, las manufacturas de Segovia y tantas otras industrias que han desaparecido, decía, merced 
a las medidas librecambistas; pero es el caso que esas manufacturas segovianas no han desaparecido en tiempo del librecambio, que todavía no ha logrado imperar, ni siquiera en tiempo del régimen protector, que funesto y todo como es, todavía representa un progreso; sino en tiempo del prohibicionismo, como que ya lo deploraba en el siglo pasado Campomanes; lo cual me hace recelar que el mejor día van a descubrir los académicos de la escuela proteccionista que los librecambistas del siglo XIX tenemos la culpa del funestísimo régimen colonial inventado por España en el siglo xvII, y de la derrota del Guadalete, y de la invasión del Imperio romano por los bárbaros, y hasta de la degollación de los niños inocentes por Herodes. Pero, en fin, yo quiero admitir como posible el hecho de que esas industrias estén condenadas a desaparecer por efecto del planteamiento de la libertad de comercio, y contesto el argumento de frente, con la ruda franqueza que nos caracteriza a los labradores, para que nadie se llame a engaño: si tales fabricantes se han equivocado, que no se empeñen en hacernos pagar los vidrios rotos, porque no los pagaremos; si tales industrias, al cabo de tanto ensayo y de tanto régimen de invernadero, no se han aclimatado, que vayan ensayando la mejor postura de morirse, que bastante tenemos nosotros con nuestra propia cruz, para que además hayamos de oficiar de cirineos a beneficio de unos ramos de producción que nada producen, especie de parásitos que ni aprovechan a la nación ni se aprovechan a sí mismos, y por los cuales, sin embargo, mueve tal algazara y gritería el proteccionismo que no parece sino que las bóvedas del cielo van a venirse abajo.

Después de todo — añadió aludiendo maliciosamente a mi profesión-, no pueden quejarse; lo mismo hacemos con los abogados y con los médicos: que son muchos en España, y no hay bastantes pleitos ni bastantes epidemias para todos; pues que litiguen entre sí o que se medicinen a sí propios, que culpa suya es no haber seguido la carrera 
de tejedores, de herreros o de comerciantes, harto más socorridas que la de médicos, abogados, ingenieros o catedráticos".

Así acabó el olivarero, y, vencida a sus razones la aldeana asamblea, demostró, aunque a decir verdad, sin gran entusiasmo, su aprobación a las conclusiones del orador, reducidas en sustancia a lo siguiente: "No pongamos obstáculo al planteamiento del librecambio parcial que se proyecta, y sigamos reclamando enérgicamente el planteamiento de la otra mitad que el Gobierno se ha dejado en el fondo de su tintero". Desde entonces ha transcurrido un año. Aquellas gentes creen que ha llegado ya la ocasión de que se cierre el círculo de lo que se ha dado en llamar compensaciones, compensando a los labradores con nuevos tratados de comercio el daño que creen se les causa con la libre introducción de primeras materias, como se compensa a los fabricantes con la libre introducción de primeras materias el daño que dijeron iban a causarles los tratados. Y habiendo sabido por los periódicos que se celebraba hoy un meeting en Madrid para aguijonear al Gobierno en punto a tratados de comercio, me han expedido el siguiente telegrama, que va a servir de punto final a mi discurso: "Suplicamos público madrileño influya Gobierno para que, como compensación ley primeras materias, perjudicial agricultura, celebre tratados comercio, Alemania, Estados Unidos, Inglaterra, Suiza, Portugal, Italia, tutti li mundi». (Grandes aplausos). 

APÉNDICES 



\section{APÉNDICE I \\ "TRATADOS DE COMERCIO" \\ Revista de Geografía Comercial \\ (año I, n. ${ }^{\circ}$ 1-2, 30-VI-1885, pp. 33-34)}

Rusia. Hace pocos días publicó la Gaceta un real decreto disponiendo que el ministro de Estado presentara un proyecto de ley pidiendo autorización para ratificar el tratado de comercio y navegación ajustado entre España y Rusia y firmado en San Petersburgo el 3 de los corrientes. Seguidamente, el día 18 de este mes, las secciones del Congreso nombraron la comisión que ha de dictaminar acerca de dicho proyecto, y que se compone de los señores conde de Esteban Collantes, Cárdenas (D. José), conde de Casa-Miranda, González Vallarino, vizconde de CampoGrande, conde de Sallent y Díaz Cobeña.

En el preámbulo del decreto citado se explican las razones del tratado y sus ventajas. Aunque el régimen arancelario existente en Rusia, dice, impide que dicho tratado se celebre con tarifas anejas, y es, por consiguiente, imposible pactar por ahora rebajas especiales, el Gobierno entiende que es de mucho interés, para favorecer el creciente desarrollo del movimiento comercial entre ambos países, el que se facilite el cumplimiento de las formalidades que requiere la navegación y se obtenga para España el trato de nación más favorecida en todo lo relativo al tránsito y depósito de mercancías y a su despacho en las aduanas.

El tratado, además, nos coloca en situación favorable para negociar sobre bases ventajosas, tan pronto como las 
circunstancias lo permitan, lo cual importa si se tiene en cuenta que, en las actuales condiciones, nuestra exportación de vinos a Rusia y la importación de maderas de Finlandia han alcanzado considerable aumento, siendo notoria su tendencia progresiva.

Portugal. El día 15 de este mes se puso a debate en la Cámara de los Pares, de Lisboa, el tratado de comercio celebrado con aquella nación y quedó autorizado el Gobierno para ratificarlo. Durará hasta 1887 , y será aplicable, por parte de España, a las Baleares, Canarias y posesiones de la costa de Marruecos, y por parte de Portugal, a las de Madera, Puerto Santo y archipiélago de las Azores.

En virtud de este tratado entran libres en Portugal los minerales en bruto no clasificados, el ganado vacuno, lanar y caballar, el corcho en bruto y en planchas, y la lana en rama, sucia o lavada, de procedencia española. El pescado fresco, o con la sal indispensable para su conservación, pagará 2,7 reis por kilogramo; la sardina salada y prensada, 3,6; los mariscos, 1,8; las frutas frescas o secas, 3,6; el corcho en tapones, 9; el aceite de olivas, 500 el decalitro; los vinos adeudarán lo mismo que en Francia.

Alemania. El día 16 de este mes se verificó en Berlín el canje de ratificaciones del convenio modificando el tratado de comercio hispano-alemán. En virtud de él, Alemania concede rebajas a España en algunos artículos cuya exportación no tiene importancia (cáscaras de limones, naranjas frescas y en salmuera, azafrán, aceitunas, algarrobas, etc.); y España renuncia a que figure el centeno en la tarifa A aneja al tratado de 12 de julio de 1883. Esta última cláusula ha sido el único móvil del convenio. España no pierde nada con esa renuncia, porque no exporta centeno a Alemania; pero Alemania gana mucho, porque le faculta para aumentar los derechos sobre el centeno austriaco, por la cláusula de nación más favorecida. De aquí la agitación que el convenio 
hispano-alemán ha producido en Austria, a punto de quebrantar profundamente al partido liberal de aquel país y comprometer la alianza existente entre los dos imperios. El príncipe de Bismarck se ha vanagloriado en el Parlamento de haber conseguido de nuestro Gobierno, con aquel convenio, inmensas ventajas sin habernos sacrificado nada.

Por su parte, Austria, según telegramas de ayer, ha propuesto a Alemania, Francia, Italia y Suiza una acción común con el objeto aparente de evitar que el cólera, que hoy aflige a España, se extienda al resto de Europa. El objetivo real de Austria es tomar represalias contra nosotros por causa del tratado hispano-alemán, que tan graves perjuicios le ocasiona.

Inglaterra. En el Libro Azul, publicado en Londres hace una semana, y que contiene las negociaciones seguidas entre Inglaterra y España desde febrero de 1884 hasta el 15 de junio corriente, para la celebración de un modus vivendi, aparece una carta de lord Granville al embajador español, señor marqués de Casa-Laiglesia, fechada el 8 de este mes, en la que expresa la esperanza de que en las negociaciones venideras se allanarán todas las dificultades que han impedido se pusiese en ejecución lo convenido el 21 de enero pasado. Añade que el Sr. Ford, que irá en breve a Madrid, recibirá oportunas instrucciones.

Un periódico de Londres, órgano del partido conservador, The Standard, decía a mediados de este mes, en una correspondencia extranjera: "La ruptura del modus vivendi no favorece a la industria española, sino a los importadores alemanes, franceses y belgas, quienes, merced a sus tratados, pueden destruir la competencia que les harían en el mercado de la Península los de Bradford y Manchester... La reanudación de las negociaciones sería recibida con gran satisfacción en los círculos comerciales, y muy especialmente por los interesados en el comercio de vinos de España, a quienes la ruptura ha causado grandes perjuicios". 
Estados Unidos. En la semana última recibió el Ministerio de Estado despachos oficiales del representante de España en Washington, participando la declaración de nulidad del convenio ajustado entre España y la República norteamericana. En la sesión del Congreso del día 26 dijo el señor ministro de Ultramar que la nueva administración organizada allí por el cambio presidencial no es favorable al tratado, pero dejó entrever la posibilidad de reanudar las negociaciones.

El tratado se consideraba como un alivio para remediar transitoriamente la desesperada situación de Cuba, no como un remedio permanente. Se prevé que antes de dos años quedará declarada libre la importación de azúcares en los Estados Unidos, como sucedió con el té y el café; pero esos dos años habrían permitido a nuestro Gobierno plantear las reformas económicas radicales que son indispensables, en los aranceles de aduanas y en los presupuestos principalmente, si España ha de conjurar el desastroso desenlace que auguran hombres previsores de todos los partidos, recordando los precedentes del levantamiento e independencia de la América española. 


\section{APÉNDICE II \\ "CUÁNDO DEBEMOS ADQUIRIR COLONIAS" \\ Revista de Geografía Comercial \\ (año I, n. ${ }^{\circ}$ 6, 31-VIII-1885, p. 87)}

El mismo ilustrado colega* publica un interesante artículo estadístico con el título "El comercio y las colonias", en el cual censura el que se haya ocupado la costa del Sáhara y se piense en nuevas adquisiciones territoriales en el golfo de Guinea, cuando tan exiguo es el comercio que hacemos con Ceuta, Canarias, Filipinas, etc.; y añade: "¿Es esto decir que abandonemos lo que poseemos? No, ciertamente, si nos conviene conservarlo; mas, para ello, hagamos que nos convenga destruyendo un sistema mercantil que nos impide todo progreso; y cuando lo hayamos sustituido por otro que nos permita alcanzar las ventajas con que se sueña, entonces será ocasión de ir extendiendo nuestras posesiones, a medida que nos tenga cuenta".

Si nuestro amigo el Sr. Ruiz de Castañeda, autor del artículo, no ha descubierto ya o no descubre de aquí a entonces, en los diez o quince años que sean precisos para terminar la reconquista de la libertad mercantil, un sistema de locomoción que permita transportar colonos a Marte o a otro planeta de condiciones habitables e inhabitado, no será posible realizar su hermoso programa de extensión sistemática y gradual de nuestras colonias; porque, lo que es

* Se refiere al periódico El Día. (N. del E.). 
en la Tierra, no existirá un palmo libre que ocupar, como que ya hoy está tan espigado el campo que, para improvisar Alemania el imperio colonial con que ha soñado, tiene que hacer presa en el patrimonio territorial de naciones constituidas, como Zanzíbar y España.

Olvidan los autores de estas máximas de prudencia política y de sentido práctico que el tiempo para colonizar es infinito; pero el espacio, limitado: que la Tierra no es cosa de goma o una como pieza de tela que se pueda ir desarrollando y extendiendo para cortar vestidos a medida de las necesidades de la familia; y que mientras todos nuestros partidos venían cohonestando su torpe abandono con la doctrina que el Sr. Castañeda sustenta en el preciso momento en que ellos, aunque tardíamente, acaban de abandonarla, Inglaterra, Francia y otras naciones acaparaban a toda prisa el planeta, no en vista de sus necesidades presentes (ninguna de esas naciones puede explotar, no ya agrícola, pero ni comercialmente siquiera, la cuarta parte de lo que poseen), sino en previsión de sus necesidades futuras. 


\section{APÉNDICE III \\ "TRATADOS DE COMERCIO" \\ Revista de Geografía Comercial \\ (año I, n. ${ }^{\circ}$ 7, 30-IX-1885, p. 92)}

Estados Unidos. Según leemos en un periódico, durante la estancia del exministro de los Estados Unidos, señor general Forster, en La Granja, quedaron convenidos los puntos capitales del tratado que habrá de celebrarse con dicha nación, con arreglo a las bases que el secretario de Estado, Mr. Layard, fijó al entrar en el poder. Si el sucesor del general Forster consigue arreglar los puntos de detalle que quedan pendientes, el tratado estará terminado a tiempo de ser presentado al Congreso de Washington tan pronto como se reúna, que será en diciembre próximo.

El corresponsal de Le Temps tiene entendido que en las bases se ha convenido que los Estados Unidos no exigirán que este tratado revista carácter de reciprocidad, con derechos diferenciales de bandera, excluyendo a los otros países de nuestro mercado colonial, como había exigido la Administración de Mr. Arthur; de modo que resultarán aplicables a todas las naciones que tengan cláusula de nación más favorecida en las Antillas las ventajas que se concedan a los Estados Unidos.

Inglaterra. La correspondencia diplomática relativa a las negociaciones comerciales de Inglaterra con España durante julio y agosto de este año, termina con una nota 
del Gabinete inglés fecha 25 de agosto, contestando a una comunicación del señor marqués de Casa-La Iglesia, en la cual el Gobierno inglés recapitula los argumentos ya presentados en apoyo de sus miras, y expresa la esperanza de que, cuando el nuevo ministro vaya a Madrid, el Gobierno español le anunciará que tiene intención de cumplir con los compromisos consignados en su declaración del 31 de diciembre, la cual concede a Inglaterra el trato de nación más favorecida.

El telégrafo ha anunciado hace pocos días, y la noticia parece oficial, que, en cuanto llegue el nuevo ministro de Inglaterra, se reanudarán las negociaciones para concertar el modus vivendi.

Ya conocen nuestros lectores el enlace múltiple de esta cuestión con la de las Carolinas. A tal propósito, escribía un periódico de Madrid, El Día (9 setiembre), lo que sigue:

"Admiramos el patriotismo de las casas españolas que han decidido romper sus relaciones comerciales con Alemania. Claro es que al traer de allí mercancías, realizan una ganancia, y que por patriotismo se privan de ella. Esa conducta exige que se les dé una compensación, la de suprimir las trabas que les impiden comprar en el mercado más ventajoso. Si de cuestiones coloniales se trata, España puede también quejarse de Inglaterra, cuya conducta en Borneo no es para olvidada nunca. Pero la libertad de comercio no es una ventaja que se da a Alemania ni a Inglaterra; es en primer término una ventaja para los españoles mismos, y bajo este punto de vista la reclamamos. Alemania importaba en España, en 1873, por valor de 4500000 pesetas; en 1883 importó por valor de 86 millones. Es absurdo conceder a una nación que tan mal nos trata privilegios que producen tal resultado; y ya que los comerciantes españoles sacrifican las comodidades artificiales de aquel mercado, es imperiosamente justo no cerrarles, artificialmente también, el que puede sustituir al que abandonan voluntariamente". 
Rusia. La Gaceta del 16 ha publicado el tratado de comercio y navegación celebrado entre España y Rusia. A causa de la política mercantil, esencialmente proteccionista de aquel imperio, el tratado resulta poco favorable al desarrollo comercial de ambos países. Rusia conserva sus tarifas aduaneras, que aplicará a nuestros productos, y las mercancías del imperio pagarán en las aduanas españolas los derechos establecidos para las naciones sin convenio especial. Solo en lo relativo al tránsito y al depósito resultan algunas facilidades que antes no existían. 



\section{APÉNDICE IV \\ «LA EXPORTACIÓN DE MANUFACTURAS CATALANAS \\ Y EL PRECIO DEL TRIGO EN ESPAÑA" \\ Revista de Geografia Comercial \\ (año II, n. ${ }^{\circ} 32$, 28-II-1887, pp. 131-132)}

Próximo a discutirse en las Cortes el recargo propuesto por algunos representantes castellanos a la partida del arancel que grava la introducción de cereales extranjeros en España, parecerá de oportunidad recordar el siguiente hecho que ha referido la revista barcelonesa Los Negocios, en un artículo titulado "Una opinión inglesa sobre la industria catalana", y cuya relación íntima e inmediata con la exteriorización colonial de España y su influencia en los países ultramarinos no tenemos que señalar, porque salta a la vista de todo el mundo.

"Apenas - dice- fue un hecho el tratado con Inglaterra, un grupo de fabricantes de algodón de aquel país envió al nuestro una de esas personas que se han hecho notables por sus facultades para investigar cuestiones comerciales e industriales, y cuya misión aquí era estudiar qué probabilidades tenía la industria inglesa de tomar parte en proveer a España de géneros de fabricación británica. Nos fue sumamente grato el oír de boca de esa notabilidad y alta inteligencia práctica que para los ingleses no había la menor probabilidad de vender sus tejidos en España de una manera normal, y que solo los artículos de fantasía o los tipos nuevos de muy escasa importancia eran los que ocasionalmente podrían expenderse aquí: nos añadió que consideraban 
a España el país más adelantado en la industria de tejidos después de Inglaterra, y que hasta sería de temer que hiciese competencia a su país en la exportación, a no existir aquí algunas dificultades para llegar al costo mínimo. Por más que nosotros sabíamos bien a qué aludiría, quisimos no darnos por entendidos, para oír su pensamiento sin la influencia de nuestras indicaciones.

Vimos confirmado por persona tan capaz lo que siempre hemos sostenido, a saber, que Cataluña puede llegar sin la menor dificultad a absorber en absoluto el mercado español; pero que antes de conseguir que la industria de aquella región traspase en grande escala los límites de España, es preciso, absolutamente preciso, que el coste de la alimentación en la zona catalana se encuentre proporcionado al que tiene en los países que pueden producir y producen para exportar.

Si fuese posible poner a pocos kilómetros de Cataluña esa región de la provincia de Cáceres donde el trigo se cotiza a 10 peseta el hectolitro, y donde la carne de carnero no valdrá más de 0,75 el kilo, la cuestión estaría resuelta; y si no en todos los artículos, de seguro tendríamos telas de algodón que exportar en competencia con las inglesas.

En la situación actual de Cataluña, de no producir las bastantes materias alimenticias para las primeras necesidades de la vida, todo sufre un encarecimiento, que es la válvula de seguridad para la industria inglesa. Tal es la opinión muy valiosa de un inglés muy práctico. Presentada la cuestión así, y su realidad es indisputable, no puede menos de ocurrir que el porvenir de la industria catalana depende totalmente de atender al abaratamiento de la vida: y aquí hay, seguramente, un problema digno de estudio en una región en donde existe espíritu de empresa y patriotismo". 


\section{APÉNDICE V \\ “ÍNDICE DE ARTÍCULOS DE JOAQUÍN COSTA \\ EN LA REVISTA DE GEOGRAFÍA COMERCIAL, Revista de Geografía Comercial (año XVII, n. ${ }^{\circ}$ 158, 1-X-1896, pp. 451-452)}

La Geografía y el comercio

Tratados de comercio de España con Rusia,

Portugal, Alemania, Inglaterra

y Estados Unidos

I, 33, 34 y 92

Congreso de navieros y consignatarios ......... I, 248

Temas y conclusiones de Geografía

comercial en el Congreso Nacional

Mercantil

Factorías españolas en la costa occidental

de África

I, 3

Comercial del Sus, Usd-Num y Tekna

I, 184

Presupuestos de España y sus colonias

para $1885-86$

I, 78

Cuándo debemos adquirir colonias

I, 87

Factorías y colonias

I, 114

España en África en 1884

I, 28

Supuesta venta de territorios españoles

I, 17

Representación política de Filipinas.

I, 94

España en África en 1888

I, 196

Petición al Gobierno sobre colonización

de Melilla

I, 106

Operación y comercio de la costa sahárica ..

I, 235

Marruecos, Alemania y España

I, 205 
Comercio en el Moghreb: Información pública

sobre exportación: Seguro contra robos:

Establecimiento español en Tetuán

I, 313

Las fronteras de Marruecos, según Duveyrier

y Habenicht

I, 293

Política hispano-marroquí ............................. I, 294

A la Gaceta de Colonia....

I, 323

Usurpaciones de los franceses.....

I, 12

Fernando Poo: su valor, según Stanley:

comercio y comunicaciones con España .

Estadísticas de la importación posible en el golfo de Guinea

I, 53

I, 72

Joló y Borneo:

convenio hispano-anglo-alemán

I, 19

Comercio exterior de Filipinas

y azúcares filipinos

I, 20

Noticias de Filipinas

I, 44

Representación política de Filipinas.....

I, 94

Varias noticias sobre las islas Marianas

y Carolinas....

I, 18

Manifiesto al país sobre la misma cuestión...

El espíritu de la nación en la cuestión

de las Carolinas

I, 64

Antecedentes de la mediación en la misma..

Las Carolinas y el archipiélago del Coral ......

Mensaje de invitación de la Sociedad

de Geografía Comercial a los Sres. Capello

e Ivens

I, 141

Discurso en el meeting de la Alhambra

I, 156

Portugal en el Zambeze .................................

Portugal en el Congo

I, 162

I, 165

Portugal en el Dahomey.....

I, 168

Portugal y España en la Conferencia de Berlín

Extensión y población de Portugal

y sus colonias

I, 171

I, 176

Noticias geográficas y comerciales de Portugal

I, 173 
La vida en la América Latina y en Argelia..... II, 110 o 133 Líneas de navegación al África Austral.

Españoles en el Congo. La Trasatlántica

española en el Golfo de Guinea............... II, 182 o 206

España y el convenio anglo-turco: rumores

sobre adhesión de España a este

convenio: condiciones de España para

garantizar la neutralidad del Canal

de Suez: actitud que le corresponde

enfrente de la cuestión egipcia .................

II, 381

Río de Oro en la antigüedad........................ II, 10 o 12

Agricultura en el desierto del Sáhara............ II, 38 o 46

Héroes hispano-marroquíes ........................... II, 146 o 170

La isla Hesperia .......................................... II, 659

España y la raza hebraico-española............... II, 143 o 168

Triple alianza del Mediodía .......................... II, 194 o 218

Portugal en China ....................................... II, 264

El estrecho de Gibraltar .............................. IV, 453 

BIBLIOGRAFÍA 

Almenar, S. (2000), "El desarrollo del pensamiento económico clásico en España", en E. Fuentes Quintana (dir.), Economía y economistas españoles. La economía clásica, Barcelona, Galaxia Gutenberg-Círculo de Lectores, vol. 4.

AZaña, M. (2007), "El cirujano de hierro según Costa", en Obras completas, vol. II, Madrid, Centro de Estudios Políticos y Constitucionales.

AzCÁrAte, G. de (1919), Necrología del Sr. D. Joaquín Costa Martinez, Madrid, Real Academia de Ciencias Morales y Políticas. [Existe una versión reciente en: Joaquín Costa. Homenaje y Memoria de la Real Academia de Ciencias Morales y Politicas en su centenario (1911-2011), Madrid, Real Academia de Ciencias Morales y Políticas, 2011].

Birnie, A. (1965), Historia económica de Europa, Barcelona, Miracle.

CABrillo, F. (1991), "Estudio preliminar", en L. Figuerola, Escritos económicos, Madrid, Instituto de Estudios Fiscales.

Camacho, J. F. (1883), Memoria sobre la Hacienda Pública de España en 1881 a 1883, Madrid, Imprenta Sucesores de Rivadeneyra.

Cheyne, G. J. G. (1972), Joaquín Costa el gran desconocido, Barcelona, Ariel.

- (1979), Confidencias politicas y personales: Epistolario Joaquín Costa-Manuel Bescós (1899-1910), Zaragoza, Institución Fernando el Católico.

- (1981), Estudio bibliográfico de la Obra de Joaquín Costa (1846-1911), Zaragoza, Guara Editorial.

- (1983), El don de Consejo. Epistolario de Joaquín Costa y Francisco Giner de los Rios (1878-1910), Zaragoza, Guara Editorial.

Ciges Aparicio, M. (1930), Joaquín Costa el gran fracasado, Madrid, Espasa-Calpe.

Costa, J. (1881), Urgencia de la Reforma Arancelaria, Discurso pronunciado en el Meeting Librecambista, Teatro de la Zarzuela, Madrid, 26 de junio. 
Costa, J. (1882a), Discurso pronunciado en el Meeting de la Asociación para la Reforma de los Aranceles de Aduanas, Teatro Apolo, Madrid, 8 de enero.

- (1882b), Urgencia del levantamiento de la suspensión de la Base Quinta de la Ley Arancelaria: necesidad de decretar la libre importación de cereales, Discurso pronunciado en el Meeting de la Asociación para la Reforma Liberal de los Aranceles de Aduanas, Teatro de la Comedia, Madrid, 21 de mayo.

- (1883), Estado actual de la cuestión arancelaria, Discurso pronunciado en el Meeting de la Asociación para la Reforma Liberal de los Aranceles de Aduanas, Teatro de la Comedia, Madrid, 24 de junio.

- (1900), Reconstitución y Europeización de España, Programa para un Partido Nacional, Liga Nacional de Productores, Madrid, Imp. de San Francisco Sales.

- (1901), El problema de la ignorancia del derecho y sus relaciones con el status individual, el referéndum y la costumbre, Discursos de recepción del Sr. D. Joaquín Costa y Martínez y de contestación del Sr. D. Gumersindo de Azcárate, Junta pública de 3 de febrero. [Existe una versión reciente en: Joaquín Costa. Homenaje y Memoria de la Real Academia de Ciencias Morales y Politicas en su centenario (1911-2011), Madrid, Real Academia de Ciencias Morales y Políticas, 2011].

- (1988), Apogeo del Liberalismo en "La Gloriosa". La reforma económica en el Sexenio Liberal (1868-1874), Madrid, Siglo XXI.

Estapé Rodríguez, F. (1989), Reflexiones en torno a Julio Senador Gómez, Madrid, Real Academia de Ciencias Morales y Políticas.

FERnÁNdez Clemente, E. (1977), Joaquín Costa y el africanismo español, Zaragoza, Ediciones Porvivir Independiente.

- (1989), Estudios sobre Joaquín Costa, Zaragoza, Prensas Universitarias de Zaragoza.

- (2006), "Joaquín Costa y la Real Academia de Ciencias Morales y Políticas", Anales de la Fundación Joaquín Costa, n. ${ }^{\circ} 22-23$.

Figuerola, L. (1863), "La cuestión de cereales", en Conferencias Libre-cambistas. Discursos pronunciados en el Ateneo Cientifico y Literario de Madrid por varios individuos de la Asociación para la Reforma de los Aranceles de Aduanas en el curso de 1862 a 1863, Madrid, Imprenta de M. Galiano.

Flores de Lemus, A. (2010), Obras, Clásicos del Pensamiento Económico Español, 3 vols., Madrid, Real Academia de Ciencias Morales y Políticas. 
Franco, G. (1927), "La teoría económica de nuestro tiempo. España", reproducido en Anales de Economía, n. ${ }^{\circ} 15$.

FuENTES QuinTANA, E. (dir.) (2000), Economía y economistas españoles. La economía clásica, Barcelona, Galaxia GutenbergCírculo de Lectores, vol. 4.

- (dir.) (2001), Economía y economistas españoles. Las críticas a la economía clásica, Barcelona, Galaxia Gutenberg, vol. 5.

Gil Novales, A. (1965), Derecho y revolución en el pensamiento de Joaquín Costa, Colección Ibérica, 4, Madrid, Península.

Gómez Benito, C., y A. ORTí (1996), Estudio crítico, reconstrucción y sistematización del corpus agrario de Joaquín Costa, Huesca, Fundación Joaquín Costa, Instituto de Estudios Altoaragoneses.

Gwiner, A. (1892), "La política comercial de España en los últimos decenios", reproducido en F. Estapé (sel.) (1973), Textos olvidados, Madrid, Instituto de Estudios Fiscales.

Lebón Fernández, C., y R. SÁnChez Lissen (2000), "Gabriel Rodríguez: un combativo economista liberal en el último tercio del siglo XIX español", en E. Fuentes Quintana (dir.), Economía y economistas españoles. La economía clásica, Barcelona, Galaxia Gutenberg-Círculo de Lectores, vol. 4.

LLuCH, E. (1988), "La "gira triunfal" de Cobden per Espanya 1846", Recerques, n. ${ }^{\circ} 21$.

- y S. Almenar (2000), "Difusión e influencia de los economistas clásicos en España (1776-1870)", en E. Fuentes Quintana (dir.), Economía y economistas españoles. La economía clásica, Barcelona, Galaxia Gutenberg-Círculo de Lectores, vol. 4.

Ministerio De Fomento (1887), Congreso de Vinicultores, Madrid, Tip. M. Ginés.

Moneva y Puyol, J. (1899), "La Asamblea Nacional de Productores", en Memoria presentada a la Liga Agraria de Granada y a la Real Sociedad Económica Granadina de Amigos del País, Zaragoza, Tipografía de Mariano Salas.

Olmet, A. del (s. f.), Los grandes españoles. Costa, Madrid, [circa 1917].

Ortega y Gasset, J. (2006-2007), Obras completas, tomos VI y VII, Madrid, Taurus.

Ortí, A. (1996), En torno a Costa. Populismo agrario y regeneración democrática en la crisis del liberalismo español, Madrid, Ministerio de Agricultura, Pesca y Alimentación, Madrid.

PÉREZ DE la DeHESA, R. (1966), El pensamiento de Costa y su influencia en el 98, Madrid, Sociedad de Estudios y Publicaciones. 
Piernas Hurtado, J. M. (1885), Tratado de Hacienda Pública y examen de la española, tomo II, 3. ${ }^{a}$ ed., Madrid, Tipogr. de M. Ginés Hdez.

- (1895), Principios elementales de la ciencia económica, Madrid, V. Suárez.

Rodríguez, A. G. (1917), Gabriel Rodríguez. Homenaje Filial, Madrid, Imprenta Helénica.

Román, R. (2003), La escuela economista española, Cádiz, Universidad de Cádiz-Universidad de Sevilla.

Sabaté Sort, M. (1996), El proteccionismo legitimado. Política arancelaria española a comienzos de siglo, Madrid, Cívitas.

SCHumpeter, A. (1971), Historia del análisis económico, Ariel, Barcelona.

SENAdOR, J. (1920), Castilla en escombros. Las leyes, la tierra, el trigo y el hambre, Imprenta V. de Montero, Valladolid.

SERRANO SANZ, J. M.. (1987), El viraje proteccionista en la Restauración. La politica comercial española 1875-1895, Madrid, Siglo XXI.

- (1997), "Los estudios económicos en España a finales del siglo XIX: historia de un estancamiento", en Industrialización en España: Entusiasmos, desencantos y rechazos. Ensayos en bomenaje al profesor Fabián Estapé, Madrid, Cívitas.

- (2001), "Canovas del Castillo y Gabriel Rodríguez: la última gran polémica arancelaria del XIX", en E. Fuentes Quintana (dir.), Economía y economistas Españoles. Las críticas a la economía clásica, Barcelona, Galaxia Gutenberg, vol. 5.

- (2011a), "Costa, economista", en Joaquín Costa. Fabricante de ideas, Zaragoza, Gobierno de Aragón.

- (2011b), "La economía en el joven Costa", Anales de la Fundación Joaquín Costa (Huesca).

- (2011c), "Un perfil poco conocido: Joaquín Costa como economista", en Joaquín Costa y la modernización de España.

VALLEJO, R. (2001), Reforma tributaria y fiscalidad sobre la agricultura y la propiedad en la España liberal, Zaragoza, Prensas Universitarias de Zaragoza.

Velarde Fuertes, J. (1961), "Joaquín Costa, Flores de Lemus y los problemas de la producción rural española", Información Comercial Española, n. ${ }^{\circ} 340$, diciembre.

- (2007), "La Real Sociedad Geográfica, de la Restauración a la Globalización", en J. Velarde Fuertes (ed.), Las sociedades científicas españoles, Madrid, Instituto de España. 
ÍNDICE 

JOAQUÍN COSTA, LIBRECAMBISTA.................................. VII

Los orígenes del librecambismo costiano .................... X

Costa, activista del librecambio..................................... XVII

El contexto de los discursos........................................ XXXV

Sobre el contenido de los discursos............................ XLV

Nuestra edición.......................................................... LXVI

DISCURSOS LIBRECAMBISTAS ...........................................

"La agricultura española y la libertad de comercio": Discurso pronunciado en el Congreso de Agricultores y Ganaderos, celebrado el día 18 de mayo de 1881, Madrid

Discurso pronunciado en el meeting librecambista sobre la "Urgencia de la reforma arancelaria", celebrado en el Teatro de la Zarzuela en Madrid el día 26 de junio de 1881

Discurso pronunciado en el meeting de la Asociación para la Reforma Liberal de los Aranceles de Aduanas, celebrado en el Teatro de Apolo de Madrid el día 8 de enero de 1882

Discurso pronunciado en el meeting sobre el tema "Urgencia del levantamiento de la suspensión de la base $5 .^{a}$ de la Ley Arancelaria: necesidad de decretar la libre importación de cereales", celebrado en el Teatro de la Comedia de Madrid el día 21 de mayo de 1882 .

Discurso pronunciado en el meeting de la Asociación para la Reforma Liberal de los Aranceles de Aduanas sobre el tema "Estado actual de la cuestión arancelaria", celebrado en el Teatro de la Comedia de Madrid el día 24 de junio de 1883. 
APÉNDICES

Apéndice I: Tratados de comercio (Revista de Geografía Comercial, 30-VI-1885)

Apéndice II: Cuándo debemos adquirir colonias (Re(vista de Geografia Comercial, 31-VIII-1885) ........

Apéndice III: Tratados de comercio (Revista de Geografía Comercial, 30-IX-1885)

Apéndice IV: La exportación de manufacturas catalanas y el precio del trigo en España (Revista de Geografía Comercial, 28-II-1887)

Apéndice V: Índice de artículos de Joaquín Costa en la Revista de Geografia Comercial (Revista de Geografia Comercial, 1-IX-1896) 


Acabose de imprimir Discursos librecambistas de Joaquín Costa el 18 de mayo de 2011, el día en que se cumplían 130 años de que pronunciase el primero de ellos y en el año del centenario de su muerte. Son textos poco conocidos en los que deslumbra la vigorosa oratoria costiana y su temprana madurez. Queda así enriquecida Larumbe. Textos Aragoneses, colección creada por Fermín Gil Encabo para el Instituto de Estudios Altoaragoneses en 1990, desde 2001 coeditada con Prensas Universitarias de Zaragoza y el Gobierno de Aragón, a partir de 2007 también con el Instituto de Estudios Turolenses y siempre abierta a la participación de otras entidades oficiales y particulares en función de títulos, autores y temas. Las proporciones del libro se atuvieron al diseño de José Luis Jiménez Cerezo según la sección áurea en homenaje a los promotores, operarios y devotos del mundo de la imprenta. Se dispuso un texto más legible armonizando tonos y texturas al tirarlo en el tipo Garamond y con formato inquarto. Para el logotipo de la colección se recurrió a la parmesana letra Bodoni como tributo de admiración a José Nicolás de Azara. La L capitular procede de las Constituciones synodales del obispo Padilla impresas por José Lorenzo de Larumbe en 1716. La viñeta que se exhibe varias veces aparece solitaria en la portada de la Palestra numerosa austriaca que convocó Luis Abarca de Bolea, editó José Amada e imprimió Juan Francisco de Larumbe en 1650 según se aprecia en el ejemplar que fue de Valentín Carderera y Solano y, antes, de Tomás Fermín de Lezaún y Tornos. Al servicio de los lectores de esta colección, se buscó hermanar provecho y disfrute; para obsequio de los amantes del libro, quedaron conjugados cánones clásicos y procedimientos hodiernos y, en pro de la cultura, se ahormaron rasgos locales con pautas universales. Yo tengo la idea de que los españoles hablamos mucho y estudiamos poco, y que una de las cosas que más y con más urgencia necesitamos, es aprender a callar.

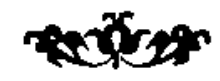





\section{Otros Larumbe}

1 Fernando Basurto, Diálogo del cazador y del pescador, edición de Alberto del Río Nogueras (1990).

2 Ramón Gil Novales, Trilogía aragonesa (La conjura. La noche del veneno. La urna de cristal), edición de Jesús Rubio Jiménez (1990).

3 José M. ${ }^{a}$ Llanas Aguilaniedo, Alma contemporánea. Estudio de Estética, edición de Justo Broto Salanova (1991).

4 Ramón J. Sender, Imán, edición de Francisco Carrasquer Launed (1992).

5 Ramón J. Sender, Primeros escritos (1916-1924), edición de Jesús Vived Mairal (1993).

6 Ana Francisca Abarca de Bolea, Vigilia y octavario de San Juan Baptista, edición de M. a Ángeles Campo Guiral (1994).

7 Pascual Queral y Formigales, La ley del embudo, edición de Juan Carlos Ara Torralba (1994).

8 Carlos Saura, iEsa luz! (guión cinematográfico), edición de Agustín Sánchez Vidal (1995).

9 Pedro Alfonso de Huesca, Diálogo contra los judios, introducción de John Tolan, texto latino de Klaus-Peter Mieth, traducción de Esperanza Ducay, coordinación de M. Jesús Lacarra (1996).

10 Constancio Bernaldo de Quirós y José M. ${ }^{a}$ Llanas Aguilaniedo, La mala vida en Madrid. Estudio psicosociológico con dibujos y fotografías del natural, edición y notas de Justo Broto Salanova, introducción de Luis Maristany del Rayo, prólogo de José Manuel Reverte Coma (1998).

11 Ramón J. Sender, El lugar de un hombre, edición de Donatella Pini (1998).

12 Francisco Carrasquer Launed, Palabra bajo protesta (antología poética), pórtico de Pere Gimferrer (1999).

13 Joaquín Maurín, May. Rapsodia infantil y iMiau! Historia del gatito Misceláneo, prefacio de Mario Maurín (1999).

14 Fragmentos de la modernidad (antología de la poesía nueva en Aragón, 1931-1945), edición de Enrique Serrano Asenjo (2000).

15 Ambrosio Bondía, Cítara de Apolo y Parnaso en Aragón, edición de José Enrique Laplana Gil (2000).

16 Ildefonso-Manuel Gil, La moneda en el suelo, edición de Manuel Hernández Martínez (2001).

17 José M. ${ }^{a}$ Llanas Aguilaniedo, Del jardín del amor, edición de José Luis Calvo Carilla (2002).

18 Jaime de Huete, Tesorina. Vidriana, edición de Ángeles Errazu (2002)

19 Benito Morer de Torla, Crónica, edición de Juan Fernández Valverde y Juan Antonio Estévez Sola (2002). 
20 Benjamín Jarnés, Salón de Estío y otras narraciones, edición de Juan Herrero Senés y Domingo Ródenas de Moya (2002).

21 Joaquín Maurín, Algol, edición de Anabel Bonsón Aventín (2003).

22 Eduardo Valdivia, iArre, Moisés!, edición de Jesús Rubio Jiménez (2003).

23 Vicente Sánchez, Lira poética, edición de Jesús Duce García (2003).

24 Miguel Servet, Obras completas. Vol. I: Vida, muerte y obra. La lucha por la libertad de conciencia. Documentos, edición de Ángel Alcalá (2003).

25 Manuel Sánchez Sarto, Escritos económicos (México, 1939-1969), edición de Eloy Fernández Clemente (2003).

26 Baltasar Gracián, El comulgatorio, edición de Luis Sánchez Laílla (2003).

27 La rebelión de las palabras. Sátiras y oposición politica en Aragón (1590-1626), edición de Jesús Gascón Pérez (2003).

28 José Vicente Torrente, El país de García, edición de Javier Barreiro (2004).

29 Hermandat et Confrayria in honore de Sancte Marie de Transfixio. Estatutos de la Cofradia de la Transfixión de Zaragoza (1311-1508), edición de Antonio Cortijo Ocaña (2004).

30 Miguel Servet, Obras completas. Vol. II: Primeros escritos teológicos, edición de Ángel Alcalá (2004).

31 Baltasar Gracián, Agudeza y arte de ingenio, edición de Ceferino Peralta, Jorge M. Ayala y José M. ${ }^{a}$ Andreu (2004).

32 Ramón J. Sender, Casas Viejas, estudio preliminar de Ignacio Martínez de Pisón, edición de José Domingo Dueñas Lorente y Antonio Pérez Lasheras, notas de Julita Cifuentes (2004).

33 Abû Bakr al-Gazzâr, el poeta de la Aljafería, Dîwân, edición bilingüe de Salvador Barberá Fraguas (2005).

34 Ramón J. Sender, Siete domingos rojos (novela), edición de José Miguel Oltra Tomás, Francis Lough y José Domingo Dueñas Lorente (2004).

35 Ramón J. Sender, Los cinco libros de Ariadna, edición de Patricia McDermott (2004).

36 Miguel Servet, Obras completas. Vol. III: Escritos científicos, edición de Ángel Alcalá (2005).

37 Ildefonso-Manuel Gil, Obra poética completa, edición de Juan González Soto (2005).

38 Jerónimo de Cáncer y Velasco, Obras varias, edición de Rus Solera López (2005).

39 Juan Polo y Catalina, Informe sobre las fábricas e industria de España (1804) y otros escritos económicos, edición de Alfonso Sánchez Hormigo (2005). 
40 Miguel Servet, Obras completas. Vol. IV: Servet frente a Calvino, a Roma y al luteranismo, edición de Ángel Alcalá (2005).

41 Juan Zonaras, Libro de los emperadores: versión aragonesa del Compendio de historia universal, patrocinada por Juan Fernández de Heredia, edición de Adelino Álvarez Rodríguez; investigación de fuentes bizantinas de Francisco Martín García (2006).

42 Joaquín Ascaso, Memorias (1936-1938). Hacia un nuevo Aragón, edición de Alejandro R. Díez Torre (2006).

43 Luciano de Samosata, Diálogo de los letrados vendibles y Tratado de que no se ha de dar crédito con facilidad a los émulos y calumniadores, edición de J. Ignacio Díez Fernández (2006).

44 Manuel de Salinas, Obra poética, edición de Pablo Cuevas Subías (2006).

45 Miguel Servet, Obras completas. Vols. V y VI: Restitución del cristianismo, edición de Ángel Alcalá (2006).

46 Juan Sala Bonañ, Relaciones del orden económico y su ciencia con los de la moralidad y del derecho y otros escritos krausistas, edición de José Luis Malo Guillén y Luis Blanco Domingo (2006).

47 Ignacio de Luzán, Obras raras y desconocidas. III. Luzán y las academias. Obra historiográfica, lingüistica y varia, coordinación de Guillermo Carnero (2007).

48 Tucídides, Dircursos de la guerra del Peloponeso: versión aragonesa de la Historia de la guerra del Peloponeso, patrocinada por Juan Fernández de Heredia, edición de Adelino Álvarez Rodríguez (2007).

49 Arbitrios sobre la economía aragonesa del siglo XVII, edición de Luis Perdices de Blas y José María Sánchez Molledo (2007).

50 Paulo Orosio, Historias contra los paganos: versión aragonesa patrocinada por Juan Fernández de Heredia, edición de Ángeles Romero Cambrón (2008).

51 Vicente Requeno y Vives, Escritos filosóficos, edición de Antonio Astorgano Abajo (2008).

52 Ramón J. Sender, La esfera, edición de Francis Lough (2010).

53 Ramón J. Sender, Proclamación de la sonrisa: ensayos, edición de José Domingo Dueñas Lorente (2008).

54 Gabriel Bermúdez Castillo, Mano de Galaxia, edición de Luis Ballabriga Pina (2008).

55 Jusepe Martínez, Discursos practicables del nobilísimo arte de la pintura, edición de María Elena Manrique Ara (2008).

56 Manuel Derqui, Todos los cuentos, edición de Isabel Carabantes de las Heras (2008).

57 Manuel Pinillos, Poesía completa (1948-1982), edición de María Pilar Martínez Barca (2008). 
58 Antonio Pérez, Aforismos de las cartas y relaciones, edición de Andrea Herrán Santiago y Modesto Santos López (2009).

59 Plutarco, Vidas semblantes: versión aragonesa de las Vidas paralelas, patrocinada por Juan Fernández de Heredia, edición de Adelino Álvarez Rodríguez (2009).

60 José Ignacio Ciordia, Poesía completa, edición de Ignacio Escuín Borao (2009).

61 Ramón Gil Novales, El penúltimo viaje, edición de Juan Carlos Ara Torralba (2009).

62 Martín García Puyazuelo, La Ética de Catón, edición de Juan Francisco Sánchez López (2009).

63 Lupercio Leonardo de Argensola, Tragedias, edición de Luigi Giuliani (2009).

64 Ignacio de Luzán, Obras raras y desconocidas. IV. Memorias literarias de París. Epístola dedicatoria de La razón contra la moda, edición de Guillermo Carnero (2010).

65 Ildefonso-Manuel Gil, Narrativa breve completa, edición de Manuel Hernández Martínez (2010).

66 Libro de las gestas de Jaime I, rey de Aragón: compilación aragonesa patrocinada por Juan Fernández de Heredia, edición de Francisco José Martínez Roy (2010).

67 Francisco La Cueva, Mojiganga del gusto; Jacinto de Ayala, Sarao de Aranjuez, edición de David González Ramírez (2010).

68 José María Conget, Trilogía de Zabala: Quadrupedumque, Comentarios (marginales) a la Guerra de las Galias, Gaudeamus, edición de Ignacio Martínez de Pisón (2010).

69 Braulio Foz, Vida de Pedro Saputo, edición de José Luis Calvo Carilla (2010). 
Larumbe. Textos Aragoneses, 70

Historia y Pensamiento

Los Discursos librecambistas nos devuelven a un Joaquín Costa poco conocido, pero particularmente interesante. Estaba comprometido con la libertad comercial completa y era defensor de un liberalismo avanzado inequívocamente modernizador. Muchos años antes del Desastre y sin haber cumplido los cuarenta, Costa se nos revela ya como un activo hombre público y un respetado intelectual. Era además un brillante orador, cuya retórica todavía hoy cautiva y divierte.
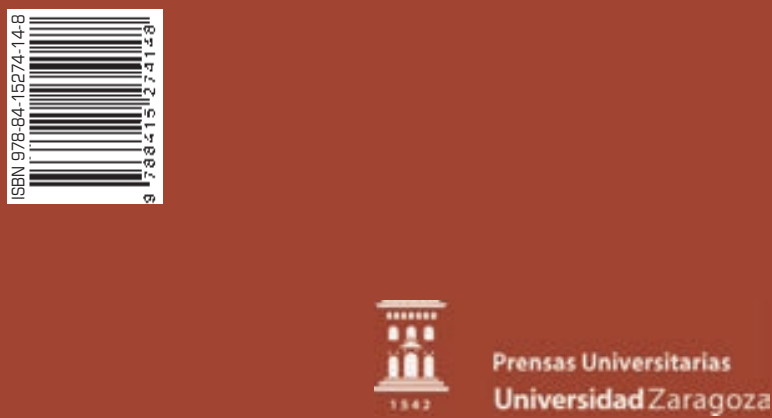